\title{
DETERMINATION OF REPORTABLE RADIONUCLIDES FOR DWPF SLUDGE BATCH 7B (MACROBATCH 9)
}

\author{
C. L. Crawford \\ D. P. DiPrete
}

December 2012

Savannah River National Laboratory Savannah River Nuclear Solutions, LLC Aiken, SC 29808

Prepared for the U.S. Department of Energy under contract number DE-AC09-08SR22470.

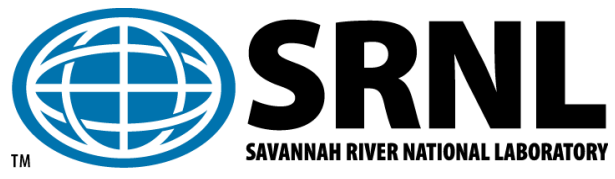




\section{DISCLAIMER}

This work was prepared under an agreement with and funded by the U.S. Government.

Neither the U.S. Government or its employees, nor any of its contractors, subcontractors or their employees, makes any express or implied:

1. warranty or assumes any legal liability for the accuracy, completeness, or for the use or results of such use of any information, product, or process disclosed; or

2. representation that such use or results of such use would not infringe privately owned rights; or

3. endorsement or recommendation of any specifically identified commercial product, process, or service.

Any views and opinions of authors expressed in this work do not necessarily state or reflect those of the United States Government, or its contractors, or subcontractors.

\section{Printed in the United States of America}

Prepared for U.S. Department of Energy 
Keywords: $D W P F$, Sludge Batch $7 b$, WAPS, Radionuclides

Retention: Permanent

\title{
DETERMINATION OF REPORTABLE RADIONUCLIDES FOR DWPF SLUDGE BATCH 7b (MACROBATCH 9)
}

\author{
C. L. Crawford \\ D. P. DiPrete
}

December 2012

Savannah River National Laboratory Savannah River Nuclear Solutions, LLC Aiken, SC 29808 


\section{REVIEWS AND APPROVALS}

\section{AUTHORS:}

C. L. Crawford, Process Technology Programs

Date

D. P. DiPrete, Analytical Development

Date

TECHNICAL REVIEWS:

C. J. Bannochie, Process Technology Programs

Date

APPROVAL:

C. C. Herman, Manager, Process Technology Programs

Date

S. L. Marra, Manager, E\&CPT Research Programs

Date

J. W. Ray, Manager, SRR Regulatory Engineering

Date 


\section{ACKNOWLEDGEMENTS}

The authors would like to acknowledge the support of the SRNL Shielded Cells technicians and supervision. Additionally, we would like to thank Ceci DiPrete (AD) and Mira Malek (AD) for assistance with the vast array of counting analyses. We also acknowledge the extensive support from D. R. Click (AD) for coordinating and directing the initial sludge slurry digestions and initially preparing the various $\mathrm{AD}$ submission forms used for the analyses. 


\section{EXECUTIVE SUMMARY}

The Waste Acceptance Product Specifications (WAPS) 1.2 require that "The Producer shall report the inventory of radionuclides (in Curies) that have half-lives longer than 10 years and that are, or will be, present in concentrations greater than 0.05 percent of the total inventory for each waste type indexed to the years 2015 and 3115”. As part of the strategy to comply with WAPS 1.2, the Defense Waste Processing Facility (DWPF) will report for each waste type, all radionuclides (with half-lives greater than 10 years) that have concentrations greater than 0.01 percent of the total inventory from time of production through the 1100 year period from 2015 through $3115^{2}$. The initial listing of radionuclides to be included is based on the design-basis glass as identified in the Waste Form Compliance Plan (WCP) ${ }^{2}$ and Waste Form Qualification Report (WQR) ${ }^{3}$. However, it is required that this list be expanded if other radionuclides with half-lives greater than 10 years are identified that may meet the greater than $0.01 \%$ criterion for Curie content.

Specification 1.6 of the WAPS, International Atomic Energy Agency (IAEA) Safeguards Reporting for High Level Waste (HLW), requires that the ratio by weights of the following uranium and plutonium isotopes be reported: U-233, U-234, U-235, U-236, U-238, Pu-238, Pu-239, Pu-240, Pu-241, and Pu242. Therefore, the complete set of reportable radionuclides must also include this set of $\mathrm{U}$ and $\mathrm{Pu}$ isotopes.

The DWPF is receiving radioactive sludge slurry from HLW Tank 40. The radioactive sludge slurry in Tank 40 is a blend of the heel from Sludge Batch 7a (SB7a) and Sludge Batch 7b (SB7b) that was transferred to Tank 40 from Tank 51. The blend of sludge in Tank 40 is also referred to as Macrobatch 9 (MB9). This report develops the list of reportable radionuclides and associated activities as a function of time. The DWPF will use this list and the activities as one of the inputs for the development of the Production Records that relate to radionuclide inventory.

This work was initiated through Technical Task Request (TTR) HLW-DWPF-TTR-2011-0004; Rev. 0 entitled Sludge Batch $7 b$ Qualification Studies ${ }^{4}$. Specifically, this report details results from performing Subtask II, Item 2 of the TTR and, in part, meets Deliverable 6 of the TTR. The work was performed following the Task Technical and Quality Assurance Plan (TTQAP), SRNL-RP-2011-00247, Rev. $0^{5}$ and Analytical Study Plan (ASP), SRNL-RP-2011-00248, Rev. $0^{6}$.

In order to determine the reportable radionuclides for SB7b (MB9), a list of radioisotopes that may meet the criteria as specified by the Department of Energy's (DOE) WAPS was developed. All radioactive U235 fission products and all radioactive activation products that could be in the SRS HLW were considered. In addition, all $\mathrm{U}$ and Pu isotopes identified in WAPS 1.6 were included in the list. This list was then evaluated and some isotopes were excluded from the projection calculations.

Based on measurements and analytical detection limits, 27 radionuclides have been identified as reportable for DWPF SB7b as specified by WAPS 1.2. The 27 reportable radionuclides are:

\begin{tabular}{cccccc}
\hline Cl-36* & Ni-59 & Ni-63 & Se-79 & Sr-90 & Zr-93 \\
Nb-93m & Tc-99 & Cd-113m & Sn-121m & Sn-126* & Cs-137 \\
Sm-151 & Th-229 & U-233 & U-234 & Np-237 & Pu-238 \\
U-238 & Pu-239 & Pu-240 & Am-241 & Pu-241 & Pu-242* \\
Am-243 & Cm-244 & Cm-246 & & & \\
\hline
\end{tabular}

* Based upon an analytical detection limit. 
The WCP and WQR require that all of the radionuclides present in the Design Basis glass be considered as the initial set of reportable radionuclides. For SB7b, all of the radionuclides in the Design Basis glass are reportable except for three radionuclides: Pd-107, Cs-135, and Th-230. At no time during the 1100year period between 2015 and 3115 did any of these three radionuclides contribute to more than $0.01 \%$ of the radioactivity on a Curie basis.

Two additional uranium isotopes (U-235 and -236) must be added to the list of reportable radionuclides in order to meet WAPS 1.6. All of the Pu isotopes (Pu-238, -239, -240, -241, and -242) and other U isotopes (U-233, -234, and -238) identified in WAPS 1.6 were already determined to be reportable according to WAPS 1.2 This brings the total number of reportable radionuclides for SB7b to 29.

The radionuclide measurements made for SB7b are similar to those performed in the previous SB7a MB8 work. Some method development/refinement occurred during the conduct of these measurements, leading to lower detection limits and more accurate measurement of some isotopes than was previously possible. Improvement in the analytical measurements will likely continue, and this in turn should lead to improved detection limit values for some radionuclides and actual measurements for still others. 


\section{TABLE OF CONTENTS}

LIST OF TABLES $\quad \mathrm{x}$

LIST OF ACRONYMS AND ABBREVIATIONS xi

1.0 INTRODUCTION 1

1.1 Background 1

1.2 Radionuclides Identified For Consideration as Reportable 1

2.0 EXPERIMENTAL 3

2.1 Direct Methods $\quad 3$

2.1.1 ICP-MS 3

2.1.2 Gamma Counting 3

2.1.3 Liquid Scintillation Counting 3

2.2 Separation Methods $\quad 3$

2.2.1 Cl-36 Method 4

2.2.2 Ni-59/-63 Method 4

2.2.3 Se-79 Method 4

2.2.4 Sr-90 Method 4

2.2.5 Gamma Counting Following Cs-137 Removal 5

2.2.6 Sn-121m Method 5

2.2.7 I-129 Method 5

2.2.8 Cs-135 Method 6

2.2.9 Pu-238/-241 Method 6

2.2.10 Am/Cm Method 6

2.2.11 Sm-151/Pm-147 Method 7

2.3 Calculated Activities of the Remaining Radionuclides 7

$\begin{array}{ll}2.3 .1 \mathrm{Nb}-93 \mathrm{~m} & 7\end{array}$

2.3.2 Pd-107 8

2.3.3 Cd-113m 8

2.3.4 Pb-210, Ra-226, Ac-227, Th-229, Th-230 and Pa-231 9

3.0 RESULTS AND DISCUSSION 11

3.1 Summary of the Activities and Radionuclides for Input 11

3.2 Additional Radionuclides Requested 13

3.3 Identification of Reportable Radionuclides 13

3.4 The Ratio by Weight of U and Pu Isotopes 16 


\section{LIST OF TABLES}

Table 1-1. List of Radioisotopes Considered for Sludge Batch 7b. 2

Table 1-2. Radioisotopes Excluded for Determination of Reportable Radioisotopes for Sludge Batch 7b 2 Table 2-1. Calculated Values of the Fission Yield Scaling Factor (FYSF) for Fourteen U-235 Fission

Products in SB7b.

Table 3-1. List of Radionuclides and Activities Used as Input to the RadCalc v. 4.1 Program ............... 12

Table 3-2. List of Additional Radionuclides and Activities Requested by DWPF in the TTR ............... 13

Table 3-3. Reportable Radionuclides in DWPF Sludge Batch 7b ..................................................... 14

Table 3-4. Reportable Radionuclides in DWPF Sludge Batch 1B through 7b ..................................... 15

Table 3-5. Uranium Isotope Distribution in DWPF Sludge Batch 7b ................................................. 16

Table 3-6. Plutonium Isotope Distribution in DWPF Sludge Batch 7b ................................................ 16 


\section{LIST OF ACRONYMS AND ABBREVIATIONS}

$\begin{array}{ll}\text { AD } & \text { Analytical Development } \\ \text { ASP } & \text { Analytical Study Plan } \\ \text { Ci } & \text { Curie } \\ \text { CST } & \text { Crystalline Silico-Titanate } \\ \text { DI } & \text { Deionized } \\ \text { DOE } & \text { Department of Energy } \\ \text { dpm } & \text { disintegrations per minute } \\ \text { DWPF } & \text { Defense Waste Processing Facility } \\ \text { FYSF } & \text { Fission Yield Scaling Factor } \\ \text { g } & \text { gram } \\ \text { HLW } & \text { High Level Waste } \\ \text { ICP-AES } & \text { Inductively Coupled Plasma - Atomic Emission Spectroscopy } \\ \text { ICP-MS } & \text { Inductively Coupled Plasma- Mass Spectrometry } \\ \text { MB2 } & \text { Macrobatch 2 } \\ \text { MB3 } & \text { Macrobatch 3 } \\ \text { MB4 } & \text { Macrobatch 4 } \\ \text { MB5 } & \text { Macrobatch 5 } \\ \text { MB6 } & \text { Macrobatch 6 } \\ \text { MB7 } & \text { Macrobatch 7 } \\ \text { MB8 } & \text { Macrobatch 8 } \\ \text { MB9 } & \text { Macrobatch 9 } \\ \text { MST } & \text { MonoSodium Titanate } \\ \mu \text { Ci } & \text { micro-Curies } \\ \text { PHA } & \text { Pulse Height Analysis } \\ \text { PTP } & \text { Process Technology Programs } \\ \text { QA } & \text { Quality Assurance } \\ \text { SB1B } & \text { Sludge Batch 1B } \\ \text { SB2 } & \text { Sludge Batch 2 } \\ \text { SB3 } & \text { Sludge Batch 3 } \\ \text { SB4 } & \text { Sludge Batch 4 } \\ \text { SB5 } & \text { Sludge Batch 5 } \\ \text { SB6 } & \text { Sludge Batch 6 } \\ \text { SB7a } & \text { Sludge Batch 7a } \\ \text { SB7b } & \text { Sludge Batch 7b } \\ \text { SCO } & \text { SRNL Shielded Cells Operations } \\ \text { SpA } & \text { Specific Activity (Ci/g) } \\ \text { SRNL } & \text { Savannah River National Laboratory } \\ \text { SRS } & \text { Savannah River Site } \\ t_{1 / 2} & \text { half-life } \\ \text { TTQAP } & \text { Task Technical and Quality Assurance Plan } \\ \text { TTR } & \text { Technical Task Request } \\ \text { WAPS } & \text { Waste Acceptance Product Specifications } \\ \text { WCP } & \text { Waste Form Compliance Plan } \\ \text { wt\% } & \text { Weight Percent } \\ \text { WQR } & \text { Waste Form Qualification Report } \\ & \end{array}$




\subsection{INTRODUCTION}

\subsection{Background}

The Waste Acceptance Product Specifications (WAPS) 1.2 require that "The Producer shall report the inventory of radionuclides (in Curies) that have half-lives longer than 10 years and that are, or will be, present in concentrations greater than 0.05 percent of the total inventory for each waste type indexed to the years 2015 and 3115." As part of the strategy to comply with WAPS 1.2, the Defense Waste Processing Facility (DWPF) will report for each waste type, all radionuclides (with half-lives greater than 10 years) that have concentrations greater than 0.01 percent of the total inventory from time of production through the 1100 year period from 2015 through $3115^{2}$. The initial listing of radionuclides to be included is based on the design-basis glass as identified in the Waste Form Compliance Plan (WCP) ${ }^{2}$ and Waste Form Qualification Reports (WQR) ${ }^{3}$. However, it is required that this list be expanded if other radionuclides with half-lives greater than 10 years are identified that may meet the greater than $0.01 \%$ criterion for Curie content.

Specification 1.6 of the WAPS, International Atomic Energy Agency (IAEA) Safeguards Reporting for High Level Waste (HLW), requires that the ratio by weights of the following uranium and plutonium isotopes be reported: U-233, U-234, U-235, U-236, U-238, Pu-238, Pu-239, Pu-240, Pu-241, and Pu242. Therefore, the complete set of reportable radionuclides must also include this set of $\mathrm{U}$ and $\mathrm{Pu}$ isotopes.

The DWPF is receiving radioactive sludge slurry from HLW Tank 40. The radioactive sludge slurry in Tank 40 is a blend of the heel from Sludge Batch 7a (SB7a), and Sludge Batch 7b (SB7b) that was transferred to Tank 40 from Tank 51. The blend of sludge in Tank 40 is also referred to as Macrobatch 9 (MB9). This report develops the list of reportable radionuclides and associated activities and determines the radionuclide activities as a function of time. The DWPF will use this list and the activities as one of the inputs for the development of the Production Records that relate to radionuclide inventory.

This work was initiated through Technical Task Request (TTR) HLW-DWPF-TTR-2011-0004, Rev. 0 entitled Sludge Batch $7 b$ Qualification Studies ${ }^{4}$. Specifically, this report details results from performing Subtask III, Item 2 of the TTR and, in part, meets Deliverable 6 of the TTR. The work was performed following the Task Technical and Quality Assurance Plan (TTQAP), SRNL-RP-2011-00247, Rev. $0^{5}$ and Analytical Study Plan (ASP), SRNL-RP-2011-00248, Rev. $0^{6}$.

\subsection{Radionuclides Identified For Consideration as Reportable}

In order to determine the reportable radionuclides for Sludge Batch $7 \mathrm{~b}$, a list of radioisotopes that may meet the criteria as specified by the Department of Energy's (DOE) WAPS was developed. All radioactive U-235 fission products and all radioactive activation products that could be in the SRS HLW were considered. No new isotopes have been added to the list in Table 1-1 since the SB7a report ${ }^{7}$. In addition, all $\mathrm{U}$ and $\mathrm{Pu}$ isotopes identified in WAPS 1.6 have been included in this list.

Table 1-1 presents the list of radioisotopes identified for consideration as reportable. The radioisotopes that were deleted from the list in Table 1-1 and the arguments that support that decision are presented in Table 1-2. 
Table 1-1. List of Radioisotopes Considered for Sludge Batch 7b

\begin{tabular}{|c|c|c|c|}
\hline Radioisotope & Radioisotope & Radioisotope & Radioisotope \\
\hline $\mathrm{C}-14^{\mathrm{a}}$ & Sn-121m ${ }^{b}$ & $\mathrm{Ra}-226^{\mathrm{d}}$ & $\mathrm{Pu}-241^{\mathrm{a}}$ \\
\hline $\mathrm{Cl}-36^{\mathrm{a}}$ & $\mathrm{Sn}-126^{\mathrm{b}}$ & $\mathrm{Ac}-227^{\mathrm{d}}$ & Am-241 ${ }^{a}$ \\
\hline $\mathrm{Ni}-59^{\mathrm{a}}$ & $\mathrm{I}-129^{\mathrm{b}}$ & Th-229 ${ }^{d}$ & $\mathrm{Pu}-242^{\mathrm{a}}$ \\
\hline Co- $60^{a}$ & $\mathrm{Ba}-133^{\mathrm{b}}$ & Th-230 ${ }^{d}$ & $\mathrm{Am}-242 \mathrm{~m}^{\mathrm{a}}$ \\
\hline $\mathrm{Ni}-63^{\mathrm{a}}$ & $\mathrm{Cs}-135^{\mathrm{b}}$ & $\mathrm{Pa}-231^{\mathrm{d}}$ & $\mathrm{Am}-243^{\mathrm{a}}$ \\
\hline $\mathrm{Se}-79^{b}$ & $\mathrm{Cs}-137^{\mathrm{b}}$ & Th- $232^{\mathrm{c}}$ & $\mathrm{Cm}-243^{\mathrm{a}}$ \\
\hline $\mathrm{Rb}-87^{\mathrm{b}}$ & $\mathrm{La}-138^{\mathrm{b}}$ & $\mathrm{U}-232^{\mathrm{a}}$ & $\mathrm{Cm}-244^{\mathrm{a}}$ \\
\hline Sr- $90^{b}$ & $\mathrm{Ce}-142^{b, c}$ & $\mathrm{U}-233^{\mathrm{a}}$ & $\mathrm{Cm}-245^{\mathrm{a}}$ \\
\hline $\mathrm{Zr}-93^{\mathrm{b}}$ & $\mathrm{Nd}-144^{\mathrm{b}}$ & U-234 ${ }^{\mathrm{d}}$ & $\mathrm{Cm}-246^{\mathrm{a}}$ \\
\hline $\mathrm{Nb}-93 \mathrm{~m}^{\mathrm{b}}$ & $\mathrm{Pm}-147^{\mathrm{b}}$ & $\mathrm{U}-235^{\mathrm{c}}$ & $\mathrm{Cm}-247^{\mathrm{a}}$ \\
\hline $\mathrm{Nb}-94^{\mathrm{b}}$ & $\mathrm{Sm}-147^{\mathrm{b}}$ & $\mathrm{U}-236^{\mathrm{a}}$ & $\mathrm{Bk}-247^{\mathrm{a}}$ \\
\hline $\mathrm{Zr}-96^{\mathrm{b}}$ & $\mathrm{Sm}-149^{\mathrm{b}}$ & $\mathrm{Np}-236^{\mathrm{a}}$ & $\mathrm{Cm}-248^{\mathrm{a}}$ \\
\hline Tc-99 ${ }^{b}$ & $\mathrm{Nd}-150^{\mathrm{b}}$ & $\mathrm{Np}-237^{\mathrm{a}}$ & $\mathrm{Cf}-249^{\mathrm{a}}$ \\
\hline $\mathrm{Cd}-113^{\mathrm{b}, \mathrm{c}}$ & Sm-151 b & $\mathrm{U}-238^{\mathrm{c}}$ & Cf $-250^{a}$ \\
\hline $\mathrm{Pd}-107^{\mathrm{b}}$ & $\mathrm{Eu}-152^{\mathrm{b}}$ & $\mathrm{Pu}-238^{\mathrm{a}}$ & Cf-251 ${ }^{a}$ \\
\hline $\mathrm{Cd}-113 \mathrm{~m}^{\mathrm{b}}$ & $\mathrm{Eu}-154^{\mathrm{b}}$ & $\mathrm{Pu}-239^{\mathrm{a}}$ & $\mathrm{Cf}-252^{\mathrm{a}}$ \\
\hline In-115 & $\mathrm{Pb}-210^{\mathrm{d}}$ & $\mathrm{Pu}-240^{\mathrm{a}}$ & \\
\hline
\end{tabular}

${ }^{a}$ Activation product

${ }^{\mathrm{b}}$ Fission product

${ }^{c}$ Naturally occurring radionuclide that resulted in the waste from processing at SRS

${ }^{\mathrm{d}}$ Decay product of an actinide isotope in SRS waste

Table 1-2. Radioisotopes Excluded for Determination of Reportable Radioisotopes for Sludge Batch 7b

\begin{tabular}{ccc}
\hline Radioisotope & Radioisotope & Radioisotope \\
\hline $\mathrm{C}-14^{\mathrm{i}}$ & $\mathrm{In}-115^{\mathrm{iii}}$ & $\mathrm{Sm}-147^{\mathrm{iii}}$ \\
$\mathrm{Rb}-87^{\mathrm{iii}}$ & $\mathrm{La}-138^{\mathrm{iii}}$ & $\mathrm{Sm}-149^{\mathrm{iii}}$ \\
$\mathrm{Nb}-94^{\mathrm{ii}}$ & $\mathrm{Ce}-142^{\text {iii }}$ & $\mathrm{Eu}-152^{\mathrm{ii}}$ \\
Zr-96 $^{\mathrm{iii}}$ & $\mathrm{Nd}-144^{\mathrm{iii}}$ & $\mathrm{Np}-236^{\mathrm{iv}}$ \\
$\mathrm{Cd}-113^{\mathrm{iii}}$ & $\mathrm{Nd}-150^{\mathrm{iii}}$ & $\mathrm{U}-232^{\mathrm{v}}$ \\
\hline
\end{tabular}

i. C-14 is volatilized during DWPF Chemical and Melt Cell processing and is not immobilized in the glass ${ }^{8}$.

ii. "Nb-94 and Eu-152 are shielded isotopes: the isobaric fission product decay chain for these stops at a stable isotope before reaching these. They are therefore produced predominately by secondary processes and are present only in very small amounts. They have not been observed in the sludge slurry"

iii. Rb-87, Zr-96, Cd-113, In-115, La-138, Ce-142, Nd-144, Nd-150, Sm-147 and Sm-149 were deleted because their long half -lives ( $>4.9 \mathrm{E} 10$ years) make their activities negligible at all times'.

iv. "No data was available for Np-236 but it is known to be made in only very small amounts in reactor irradiation. Np-236 is a minor product of fast neutron spallation. It was neglected". 9

v. "U-232 is present only in very small amounts and decays rapidly compared to other actinide isotopes that are much more abundant (it is primarily obtained as a contaminant at a few ppm from the reactor irradiation of Th-232)". 9 


\subsection{EXPERIMENTAL}

The details for sample acquisition from Tank 40 - SB7b, preparation of the digestions, and measurement of the elemental composition have been published separately ${ }^{10}$. The results for those radionuclides that required additional separation techniques, that were not included in the referenced report, have been included in this report. Details of the separation and detection methods are provided. All measurements and counting analyses were done by SRNL Analytical Development (AD). Most of the separation methods were also performed by AD personnel except for the Se-79, I-129 and Am/Cm methods that were initially performed by Process Technology Programs (PTP) personnel with guidance from AD personnel and then submitted to $\mathrm{AD}$ personnel for further separations and/or counting.

\subsection{Direct Methods}

\subsubsection{ICP-MS}

Inductively coupled plasma - mass spectrometry (ICP-MS) was employed to analyze separate subsamples of the aqua regia digestions of the adjusted Tank 40 - SB7b dried solids described in a previous report $^{10}$. Measurements were first converted to weight percents on a dried solids basis and then converted to activities using the specific activity of each isotope taken from Reference 11. The isotopes obtained from direct ICP-MS measurements included: Zr-93, Tc-99, Th-232, U-233, U-234, U-235, U-236, Np-237, U-238, Pu-239, Pu-240, and Pu-242.

\subsubsection{Gamma Counting}

Gamma Pulse Height Analysis (PHA) was performed on separate sub-samples of the alkali fusion (also known as "peroxide fusion") digestions of the adjusted Tank 40 - SB7b dried solids described in a previous report ${ }^{10}$. Detectors were carefully calibrated with known standards. Since detection efficiencies for gamma-rays vary with energy, they were determined for these specific radionuclide energies during the calibration process. The counting geometry was established during calibration and carefully duplicated for these measurements. Samples were diluted as necessary to achieve accurate counting. The isotopes obtained from Gamma PHA counting included: Cs-134 (detection limit) and Cs137.

\subsubsection{Liquid Scintillation Counting}

Liquid scintillation counting was performed on separate sub-samples of the alkali fusion digestions of the adjusted Tank $40-$ SB7b dried solids described in a previous report ${ }^{10}$. The scintillation cocktail used for the analysis was Ultima Gold AB since it is specifically formulated for alpha-beta discrimination and is the best choice for samples dissolved in mineral acids. Measurements were performed on one of three Packard Instruments which automatically correct for quenching and many other interference problems commonly associated with liquid scintillation counting. This method was used to determine total Beta activity. Diluted aliquots of digested slurry were analyzed for 10 minutes. Diluted aliquots of digested slurry were also spiked with an alpha standard and analyzed for 10 minutes to measure and correct for any alpha/beta discrimination cross-talk issues.

\subsection{Separation Methods}

These analytical methods involved separation techniques that enabled radionuclides that were at low concentrations to be measured more accurately and to determine more reliable and lower detection limits. The techniques and methodology for these separations are maintained by SRNL AD and will only be summarized here. Aliquots of the alkali fusions or the aqua regia dissolutions were analyzed along with blanks. In all cases, the activity in the blanks did not contribute any significant activity to the 
radionuclides being analyzed. For the special cases involving Se-79, I-129 and Am/Cm aliquots of the sludge slurry were initially treated in the shielded cells for various separation steps (via the methodology detailed below) and then submitted to AD for further separation and/or counting.

\subsubsection{Cl-36 Method}

Aliquots of Sludge Batch $7 \mathrm{~b}$ aqua regia dissolution were initially rendered caustic and subjected to two Monosodium Titanate (MST) and Crystalline Silico-Titanate (CST) based decontamination steps. The resins and insoluble elements (i.e. Actinides, lanthanides, strontium and yttrium) were filtered off, decontaminating the solution. The solutions were then acidified with nitric acid and further decontaminated with Bio-Rad AMP and Eichrom Diphonix resins. The $\mathrm{Cl}$ in the samples was subsequently precipitated as $\mathrm{AgCl}$. The $\mathrm{AgCl}$ precipitate was counted using gas flow proportional counter analysis. The $\mathrm{AgCl}$ precipitate was then activated by neutron activation analysis to determine $\mathrm{Cl}$ losses during the processes. The $\mathrm{HCl}$ used to digest the samples initially was used to trace Cl-36 throughout the processes. The chlorine yields were used to correct Cl-36 results for any losses.

\subsubsection{Ni-59/-63 Method}

This separation is based on isolation of $\mathrm{Ni}$ from the dissolved sludge using a column containing dimethylglyoxime as an extractant that is specific for Ni. Each of the solutions resulting from the alkali fusions of the four samples of dried sludge slurry was spiked with a stable Ni carrier to trace the $\mathrm{Ni}$ separation and was then passed through a column containing the above extractant. The absorbed Ni was then eluted from each column. The Ni-59 was measured in the eluted solutions by its characteristic Xrays and Ni-63 by its beta particles. Total $\mathrm{Ni}$ in each eluted solution was measured by inductively coupled plasma atomic emission spectroscopy (ICP-AES). The radiochemical Ni analyses were corrected for the Ni carrier recoveries as measured by ICP-AES.

\subsubsection{Se-79 Method}

Four aliquots of wet sludge slurry were spiked with a known amount of stable Se as a carrier. The samples were digested with concentrated nitric acid. The Fe in the dissolutions was reduced to Fe(II) using ascorbic acid to ensure it would not interfere with subsequent decontamination steps designed to extract Y-90, the lanthanides and the actinides from the Se traced dissolutions. The dissolutions were then treated with resins (Bio-Rad AMP-1, Eichrom Sr, RE, and Actinide resins) to reduce levels of Sr90, Cs-137, Y-90, the lanthanides and the actinides to levels low enough to allow for their removal from the Shielded Cells and submission to AD. The Se traced decontaminated dissolutions were then further decontaminated with Bio-Rad AMP-1, Eichrom Sr and RE resin treatments. The total Se was reduced to Se metal using titanium (III) chloride, hydroxylamine hydrochloride, and ascorbic acid. The precipitated Se metal was then washed repeatedly with deionized water and dilute nitric acid. The Se metal was then dissolved with concentrated $\mathrm{HBr}$, and the resulting $\mathrm{SeBr}_{4}$ was extracted by solvent-solvent extraction using a tri-butyl phosphate/n-paraffin solvent extraction system. The Se was back extracted from the solvent. Aliquots of the purified Se fraction were then analyzed. A portion was neutron activated in a Cf-252 neutron source at SRNL to determine the total amount of Se present in order to calculate the recovery of Se from the radiochemical separation. A second portion was counted by liquid scintillation to determine the Se-79 beta activity. The yields of the stable Se carrier were applied to the Se-79 beta activity result to determine Se-79 activities in the sample aliquots initially treated.

\subsubsection{Sr-90 Method}

Aliquots of each sample from the alkali fusions ${ }^{10}$ were spiked with a stable $\mathrm{Sr}$ carrier, and a stable Ce carrier. The Sr carrier was used for separation yielding purposes and the Ce carrier was used to enhance the separation rates of undesirable isotopes such as Y-90, the lanthanides or the actinides. The spiked sample aliquots were initially oxidized using nitric acid. The $\mathrm{Sr}$ in the samples was extracted using commercially available Sr extraction resin. This resin also extracts some of the Pu under the conditions 
used to extract the Sr. The Pu was washed from the resin using an oxalic acid/nitric acid mixture. The $\mathrm{Sr}$ was eluted from the resin, and the resulting solution concentrated. A portion of the purified $\mathrm{Sr}$ solution was neutron activated in a Cf-252 neutron activation facility at SRNL to determine the total $\mathrm{Sr}$ and in order to calculate the fraction of $\mathrm{Sr}$ isolated by the procedure. A second portion of each of the $\mathrm{Sr}$ fractions was stored for five to seven days to allow Y-90 to grow in. Each fraction was then counted by liquid scintillation analysis to determine the Y-90 activity. The Sr-90 beta activity in each case was calculated from the Y-90 activity. The yields of the stable Sr carriers were applied to the Sr-90 beta activity results to determine Sr-90 activities in the original aliquots of the solutions resulting from the dissolution of the dried sludge slurry samples.

\subsubsection{Gamma Counting Following Cs-137 Removal}

This method was used to determine Co-60, Ru-106, Sb-125, Sn-126, Ba-133, Ce-144, Eu-154, Eu-155, and Am-241. These gamma emitters could not be determined directly because of the high Cs-137 activity in the samples. Consequently the Cs-137 was removed. Aliquots of each of the four alkali fusions ${ }^{10}$ of the dried sludge slurry samples were treated with two batch additions of an ammonium phosphomolybdate resin to selectively remove the Cs-137 from the aliquots. This allowed gammas for isotopes at low concentrations to be detected or allowed lower detection limits to be determined for those isotopes that were not detected. The Cs-137 decontaminated aliquots were then gamma counted in two different detectors. The first was a high purity coaxial germanium detector to detect the gamma rays from Ru-106, Sb-125, Sn-126, Ba-133, Ce-144, Eu-154, Eu-155, and Am-241. Only Co-60, Eu-154, Eu-155, and Am-241 were detected. Because of their low concentrations the other isotopes were not detected. To obtain reliable and lower detection limits for these radionuclides, each of the solutions was counted for four hours or more. The detection limits were used to calculate the maximum activity of each for input to the projection calculations. Of this group of radionuclides, only Sn-126 and Ba-133 have half-lives greater than 10 years. Even though the others have half-lives less than 10 years, their activities were included to calculate the total Curies present in SB7b at the selected decay times except for Ru-106 and Ce-144 which are discussed in Section 3.2.

\subsubsection{Sn-121m Method}

Aliquots of alkali fusions ${ }^{10}$ were spiked with Sn-113. The aliquots were converted to a chloride matrix with hydrochloric acid, and elemental tin was extracted from the matrix using anion exchange. Tin was eluted with dilute nitric acid, and the tin extract was analyzed by low energy gamma-ray spectrometry for $\mathrm{Sn}-121 \mathrm{~m}$ and for the Sn-113 tracer. The Sn-121m results were then yielded with the results from the Sn113 recovery

\subsubsection{I-129 Method}

The radionuclide I-129 is a long-lived beta emitting fission product $\left(\mathrm{t}_{1 / 2}=1.6 \mathrm{E}+07\right.$ years $)$ that is in SRS wastes. Aliquots of wet sludge slurry were spiked with a known amount of stable KI to act as an iodine tracer/carrier. The samples were digested with $8 \mathrm{M}$ nitric acid. The traced samples were then rendered caustic, precipitating out the actinides, lanthanides, Sr-90 and Y-90, among some other radioactive species. MST was added to further decontaminate the caustic dissolutions from Sr-90, Y-90, the actinides and the lanthanides. CST was added to reduce levels of Cs-137. The treated solutions were filtered, and the decontaminated filtrate was then removed from the Shielded Cells for submission to AD. The samples were decontaminated a final time with a resin treatment to remove Cs-137 and the actinide elements. The solution was then treated with $\mathrm{AgNO}_{3}$ in order to precipitate the iodide ion as AgI. The precipitate was analyzed by low energy photon spectrometry to determine the amount of I-129 present. I-129 is detected by its characteristic gamma and x-ray emissions. The precipitate was then neutron activated in a Cf- 252 neutron source at SRNL to determine the total amount of iodine present in order to calculate the recovery of I-129 in the radiochemical separation. 


\subsubsection{Cs-135 Method}

Cs-135 is a long-lived beta emitting fission product ( $\mathrm{t}_{1 / 2}=3.0 \mathrm{E}+06$ years). Due to its long life relative to Cs-137, and its correspondingly lower activity relative to Cs-137, beta counting is incapable of providing an effective means for quantifying Cs-135. Due to the dominance of natural Ba-135 in the waste, ICPMS can only be used to quantify Cs-135 if the $\mathrm{Ba}$ is first removed. Given this situation, a radiochemical separation is performed to isolate Cs prior to measurements. Aliquots of the solids digested solution from aqua regia dissolution are alkalized, and then $\mathrm{Cs}$ is extracted into a BOB-calix extractant. The purified Cs is stripped from the extractant utilizing dilute nitric acid, and the resulting nitric acid solutions are analyzed by ICP-MS. Recoveries of the analyses are monitored one of two ways: 1) by ratioing the postpurification Cs-133 mass signal to the prepurification Cs-133 mass signal (the 133 mass signal has no isobaric interferences); or 2) performing gamma PHA of the purified aliquot and ratioing the postpurification Cs-137 content to the pre-purification Cs-137 content. The post-purification Cs-135 measurements were adjusted for losses identified by the recoveries.

Prior to recent development of this Cs isoloation method from Ba that was first used for SB7a and now for SB7b, the Cs-135 values were calculated by ratioing the measured Cs-135 and Cs-137 ICP-MS values from supernate. This is possible because the Ba- 135 and Ba- 137 are insoluble in caustic supernate. By using the ratio of Cs-135 to Cs-137 in the supernate, and the amount of Cs-137 in the sludge slurry, the activity for Cs-135 in the sludge slurry can be calculated. This calculated value for Cs-135 in SB7b was performed using the measured ICP-MS values for mass 135 and 137 from the supernate equal to $1.75 \mathrm{E}-05$ $\mathrm{wt} \%$ and $4.62 \mathrm{E}-05 \mathrm{wt} \%$, respectively, giving a mass 135: mass 137 ratio of 0.3798 . This ratio was used to calculate the Cs-135 in the sludge slurry by multiplying by the measured Cs-137 in the slude slurry, giving $0.3798 \times 7.41 \mathrm{E}-04 \mathrm{wt} \%=2.81 \mathrm{E}-04 \mathrm{wt} \% \mathrm{Cs}-135$. This calculated value is indeed similar to the analzyed average Cs- 135 value of $2.88 \mathrm{E}-04 \mathrm{wt} \%$ from quadruplicate analyses of the aqua regia dissolved sludge slurry. This comparison of the calculated Cs-135 vs. the analyzed Cs-135 value lends credence to previous determinations by calculational methods only.

\subsubsection{Pu-238/-241 Method}

$\mathrm{Pu}-241$ is a beta-emitting $\mathrm{Pu}$ isotope that cannot be measured directly in the dissolved dried sludge slurry solutions because of its low concentration. $\mathrm{Pu}-241$ has a relatively short half-life $\left(\mathrm{t}_{1 / 2}=15\right.$ years $)$. Its concentration, along with that for $\mathrm{Pu}-238$, was determined by isolating the $\mathrm{Pu}$ from each solution by a thenoyltrifluoroacetone extraction procedure. The extracted $\mathrm{Pu}$ was then analyzed by beta and alpha counting to determine the ratio of beta activity from $\mathrm{Pu}-241$ to the alpha activity from the other isotopes of $\mathrm{Pu}(\mathrm{Pu}-238, \mathrm{Pu}-239, \mathrm{Pu}-240$, and $\mathrm{Pu}-242)$. In the original dissolution solutions, the total alpha activity from the Pu isotopes was determined by alpha counting and ICP-MS. Knowing the total alpha activity from $\mathrm{Pu}$ in the solutions resulting from the extraction allows the concentration of $\mathrm{Pu}-241$ in the original dissolution solutions to be calculated using the beta/alpha ratio determined in the extracted solution. In the extracted solution, the alpha counting technique also gives the alpha counts due specifically to $\mathrm{Pu}-$ 238 so that the total amount of $\mathrm{Pu}-238$ can be determined. The activities of these two radionuclides were then used in the calculations to determine the reportable radionuclides.

\subsubsection{Am/Cm Method}

This method was used for Am-241, Am-242m, Cm-242, Am-243, Cm-243, Cm-244, Cm-245, Cm-246, $\mathrm{Cm}-247, \mathrm{Cm}-248, \mathrm{Bk}-247, \mathrm{Cf}-249$, Cf-250, Cf-251, and Cf-252. These radionuclides are neutron activation products produced in the SRS reactors. These isotopes are difficult to measure because of their low concentrations in the sludge slurry and the dilutions necessary to get the dissolved slurry samples out of the Shielded Cells. Of these isotopes, the Am-241 can be easily and accurately analyzed directly by long term gamma counting of the dissolved sludge (see Section 2.1.2). For the other radionuclides listed above, a separation method has been developed by $\mathrm{AD}$ for isolating $\mathrm{Am}, \mathrm{Cm}, \mathrm{Bk}$ and $\mathrm{Cf}$ from a wet sludge slurry solution. The slurry is digested in the Shielded Cells with concentrated nitric acid. Ascorbic 
acid is then added, followed by Bio-RAD AMP and U-TEVA to remove Cs-137, and the tetravalent and hexavalent actinides. This mixture is then filtered. The actinides are then extracted from the dissolution filtrate using a commercially available ion exchange resin (Eichrom RE). As Y-90 coextracts with the trivalent actinides on RE resin, the treated samples were held in the Shielded Cells for nine days to allow the Y-90 to decay before they were removed and submitted to AD. The solutions were purified further with a second RE resin extraction followed by an Eichrom Ln resin extraction. The Am, Cm, Bk, and Cf extracts were then analyzed by alpha and low energy gamma counting techniques as well as by ICP-MS. The radionuclides Cm-242, Am-242m, Cm-244, and Cf-252 were measured by alpha spectroscopy, Am241, Am-243, Cm-243, Cm-245, Cf-249, and Cf-251 were measured by low energy gamma spectroscopy, and Cm-245, Cm-246, Cm-247, Bk-247, Cm-248 and Cf-250 were measured by ICP-MS. The fraction of each actinide element isolated by this ion exchange technique was determined by comparing the measured concentrations of Am-241 in the eluted solutions with their respective concentration in the original dissolved slurry that was measured by direct gamma counting of Cs-137 removed aliquots of the dissolved slurry.

By using this technique, the radionuclides Am-242m, Am-243, Cm-242, Cm-244, Cm-245, and Cm-246 were detected and measured along with the Am-241. All the other radionuclides had concentrations below the detection limit of the analytical methods. These radionuclides were Cm-243, Cm-247, Bk247, Cm-248, Cf-249, Cf-250, Cf-251 and Cf-252. For these, the detection limits were then used as the maximum concentrations or activities that could be present.

\subsubsection{Sm-151/Pm-147 Method}

Aliquots of each sample from the alkali fusions ${ }^{10}$ were spiked with a stable Sm carrier. The Sm carrier was used for separation yielding purposes. The spiked sample aliquots were initially oxidized using nitric acid. The Sm and Pm along with other trivalent species in the samples were extracted using Eichrom RE resin. The Sm and Pm where then extracted from the other radionuclides present using Eichrom Ln resin. A portion of the purified $\mathrm{Pm} / \mathrm{Sm}$ solution was neutron activated in a Cf-252 neutron activation facility at SRNL to determine the total Sm and in order to calculate the fraction of Sm isolated by the procedure. A second portion of each of the $\mathrm{Pm} / \mathrm{Sm}$ fractions was then counted by liquid scintillation analysis to determine the Pm-147 and Sm-151 activity. The Pm-147 measurement was conducted using a higher energy beta window which was free of any interference from the low energy $\mathrm{Sm}-151$ beta. The Sm-151 beta result is corrected for any Pm-147 events occurring in its beta counting window when necessary. The yields of the stable Sm carriers were applied to the Sm-151 and the Pm147 beta activity results to determine Sm-151 and Pm-147 activities in the original aliquots of the solutions resulting from the dissolution of the dried sludge slurry samples. A Pm-147 spiked sample was run through the process to monitor and correct for any slight differences in the chemical recoveries of Sm and Pm.

\subsection{Calculated Activities of the Remaining Radionuclides}

\subsubsection{Nb-93m}

The radionuclide $\mathrm{Nb}-93 \mathrm{~m}\left(\mathrm{t}_{1 / 2}=16.1 \text { years }\right)^{13}$ is in SRS HLW as the decay product of the radioactive fission product $\mathrm{Zr}-93\left(\mathrm{t}_{1 / 2}=1.53 \mathrm{E}+06\right.$ years $)$. For previous sludge batches both the $\mathrm{Zr}-93$ and $\mathrm{Nb}-93 \mathrm{~m}$ became reportable after the waste was $\sim 100$ years old. ${ }^{21,22,23,24,25,26,7}$ The concentration of Nb-93m during SB7b vitrification can be calculated if the age of the sludge and the concentration of $\mathrm{Zr}-93$ are known. 
The age of the waste can be calculated from the measured concentration at mass 90 that is composed of Sr-90 $\left(\mathrm{t}_{1 / 2}=28.5\right.$ years $)$ and its daughter Y-90 ( $\mathrm{t}_{1 / 2}=2.67$ days $)$ that decays to stable $\mathrm{Zr}-90$. The radionuclide $\mathrm{Sr}-90$ is the initial long lived radioactive product of the isobaric decay chain at mass 90 . In the ICP-MS analysis of the aqua regia dissolutions of the SB7b total solids, the concentration at mass 90 which is composed of Sr-90, Y-90, and Zr-90 was $0.0223 \mathrm{wt} \%$. The concentration of Sr-90 determined by radioactive counting was $0.00931 \mathrm{wt} \%$ (see Section 2.2.4). The ratio of these two values representing the fraction of Sr-90 that remained in this sludge is 0.417 . With the half-life of Sr-90 and standard equation for radioactive decay ${ }^{12}$, the age of the sludge can be calculated to be 36 years. If one takes the same ratio of radioactive Sr-90 divided by the mass 90 predicted by the fission yield scaling factor (FYSF) (see Section 2.3.3) of $0.0332 \mathrm{wt} \%$ to give 0.280 , the calculated age of the sludge is older giving 53 years. The more conservative age of waste equal to 53 years is used in this work to calculate various radioactive decay products.

The concentration of $\mathrm{Zr}-93$ in SB7b measured by ICP-MS is $0.0184 \mathrm{wt} \%$. Because of the large difference in the half-lives of $\mathrm{Zr}-93$ and its radioactive daughter $\mathrm{Nb}-93 \mathrm{~m}$, these radionuclides are in secular equilibrium. Consequently, the initial concentration ( $\mathrm{wt} \%$ ) of $\mathrm{Nb}-93 \mathrm{~m}$ as input to the decay calculations can be calculated from the age of the waste and radioactive decay equation for two radionuclides that are in secular equilibrium as shown in Equation 5-4 on page 130 in Reference 12.

\subsubsection{Pd-107}

The noble metal Pd-107 is a pure beta emitter with a very long half-life ( $\mathrm{t}_{1 / 2}=6.5 \mathrm{E}+06$ years). This radionuclide could not be detected in the SB7b dissolved dried slurry samples by ICP-MS due to the presence of natural silver. Natural Ag contains the isotope Ag-107, which interferes with the measurement of Pd-107. The concentration of Pd-105 could be measured in the solutions thus the concentration of Pd-107 was calculated from the concentration of Pd-105. This was done by multiplying the ratio of the product of the fission yields and masses for Pd-107 and Pd-105 by the measured wt $\%$ for Pd-105 as determined by ICP-MS.

\subsubsection{Cd-113m}

With a half-life of 13.7 years and specific activity of $217 \mathrm{Ci} / \mathrm{g}^{11}, \mathrm{Cd}-113 \mathrm{~m}$ may also qualify as a WAPS reportable radionuclide. However, $\mathrm{Cd}-113 \mathrm{~m}$ primarily decays by $\beta$ emission and thus would require a careful separation technique to measure in sludge slurry. Also, the determination of Cd-113m by ICPMS of the dissolved dried solids is essentially impossible because of the presence of natural $\mathrm{Cd}$ in the sludge. Natural Cd is $12.3 \%$ Cd-113 with a half-life greater than $1.1 \mathrm{E} 11$ years ${ }^{13}$. This makes its activity negligible at all times ${ }^{9}$. Finally, the fission yield of Cd- $113 \mathrm{~m}$ is very small, $1.66 \mathrm{E}-04 \%{ }^{14}$, and thus its concentration is expected to be very small in the HLW sludge.

An upper limit of the mass concentration of Cd-113m can be estimated by using the FYSF ${ }^{15}$. The FYSF relates the concentration of a fission product in the total sludge solids to the fission yield and the atomic mass of that fission product. The atomic mass of that isotope has to be included in the equation because fission yields are given in terms of atoms produced per 100 fissions of U-235 and not in terms of mass percent of the isotope produced. The equation for the concentration in weight percent is then:

$$
\text { Concentration }(\mathrm{wt} \%)=\text { FYSF (fission yield } \mathrm{x} \text { atomic mass) }
$$

Thus the FYSF for each measured isotope can be calculated from the Equation 2.

$$
\mathrm{FYSF}_{\mathrm{i}}=\mathrm{wt} \% \%_{\mathrm{i}} /\left(\mathrm{fy}_{\mathrm{i}} \mathrm{x} \mathrm{am}_{\mathrm{i}}\right)
$$


Where $\mathrm{FYSF}_{\mathrm{i}}=$ the fission yield scaling factor based on isotope $\mathrm{i}$

$\mathrm{wt}_{\mathrm{t}} \mathrm{o}_{\mathrm{i}}=$ the weight per percent of isotope $\mathrm{i}$ in the HLW total dried solids

$\mathrm{fy}_{\mathrm{i}}=$ the fission yield of isotope $\mathrm{i}$

$\mathrm{am}_{\mathrm{i}}=$ the atomic mass of isotope $\mathrm{i}$.

Several of the U-235 fission products have the six critical chemical and nuclear properties that allow calculation of a constant FYSF for a particular sludge. These properties are discussed in Reference 15. In SB7b, there are 14 isotopes that have these six properties. The FYSF's calculated for these 14 isotopes are presented in the Table 2-1. The measured concentrations in the Table 2-1 were determined by ICP-MS analysis of four samples of dissolved SB7b total solids by the aqua regia method. The average of the FYSF's calculated for the 14 fission products is $8.20 \mathrm{E}-05$ with a relative standard deviation of $14 \%$.

Table 2-1. Calculated Values of the Fission Yield Scaling Factor (FYSF) for Fourteen U-235 Fission Products in SB7b

\begin{tabular}{cccc}
\hline Isotope & $\begin{array}{c}\text { Measured } \\
\text { Wt\% of Total } \\
\text { Solids }\end{array}$ & Fission Yield & FYSF \\
\hline Ru-101 & $4.11 \mathrm{E}-02$ & 5.20 & $7.83 \mathrm{E}-05$ \\
$\mathrm{Ru}-102$ & $3.81 \mathrm{E}-02$ & 4.30 & $8.68 \mathrm{E}-05$ \\
$\mathrm{Rh}-103$ & $2.07 \mathrm{E}-02$ & 3.03 & $6.63 \mathrm{E}-05$ \\
$\mathrm{Ru}-104$ & $2.26 \mathrm{E}-02$ & 1.88 & $1.16 \mathrm{E}-04$ \\
$\mathrm{La}-139$ & $7.30 \mathrm{E}-02$ & 6.41 & $8.19 \mathrm{E}-05$ \\
$\mathrm{Ce}-140$ & $6.90 \mathrm{E}-02$ & 6.22 & $7.93 \mathrm{E}-05$ \\
$\mathrm{Pr}-141$ & $6.59 \mathrm{E}-02$ & 5.80 & $8.06 \mathrm{E}-05$ \\
$\mathrm{Ce}-142$ & $6.63 \mathrm{E}-02$ & 5.85 & $7.98 \mathrm{E}-05$ \\
$\mathrm{Nd}-143$ & $6.37 \mathrm{E}-02$ & 5.96 & $7.48 \mathrm{E}-05$ \\
$\mathrm{Nd}-144$ & $6.37 \mathrm{E}-02$ & 5.50 & $8.05 \mathrm{E}-05$ \\
$\mathrm{Nd}-145$ & $4.44 \mathrm{E}-02$ & 3.93 & $7.78 \mathrm{E}-05$ \\
$\mathrm{Nd}-146$ & $3.55 \mathrm{E}-02$ & 3.00 & $8.11 \mathrm{E}-05$ \\
Sm-147 & $2.48 \mathrm{E}-02$ & 2.25 & $7.48 \mathrm{E}-05$ \\
Sm-148 & $2.22 \mathrm{E}-02$ & 1.67 & $8.99 \mathrm{E}-05$ \\
\hline Average & - & - & $\mathbf{8 . 2 0 E - 0 5}$ \\
\hline
\end{tabular}

With the FYSF for SB7b, the maximum possible concentration in terms of weight percent of dried solids can be estimated for the other U-235 fission products. These estimations are a maximum for the other fission products because they do not have the necessary six properties as the fission products given in Table 2-1. For example, the radionuclide Cd-113m has a very large neutron absorption cross section $\left(20,000\right.$ barns $\left.^{13}\right)$, and thus it was transmuted in the reactors at SRS to stable Cd-114 while the reactors were in operation. Consequently, the concentration calculated for Cd-113m with Equation 1 and a fission yield of $1.66 \mathrm{E}-04 \%$ can be considered the maximum concentration and is estimated below:

$$
\text { Concentration Cd-113m }(\mathrm{wt} \%)=8.20 \mathrm{E}-05 \times 1.66 \mathrm{E}-04 \times 113=1.54 \mathrm{E}-06 \mathrm{wt} \% \text {. }
$$

\subsubsection{Pb-210, Ra-226, Ac-227, Th-229, Th-230 and Pa-231}

Calculations of the quantities of radioactive decay products Pb-210, Ra-226, Ac-227, Th-229, Th-230 and $\mathrm{Pa}-231$ were performed based on the calculated value that the waste is 53 years old. Parent radionuclides used in these calculations are indicated below in Table 3-1 of Section 3.1. In calculating the 
concentrations of decay products, the first step was to calculate the concentrations of the parent radionuclides 53 years ago. Utilizing the standard activity decay relationship ${ }^{12}$, the parent concentration in 1959 was calculated as the product of the current concentration (in 2012) and the term $\left[\exp \left(0.693 * 53 / t_{1 / 2}\right)\right]$, where $t_{1 / 2}$ is the half-life of the parent radionuclide in units of years. The second step was to determine the decay product concentration in 2012, utilizing a decay/ingrowth calculation to quantify the progeny arising from 53 years of decay of the 1959 parent concentration. RadCalc 4.1 software (see Section 3.3 below) was utilized for these calculations.

Th-230 is long-lived alpha emitting radionuclide $\left(\mathrm{t}_{1 / 2}=7.5 \mathrm{E}+04\right.$ years) that is a decay product of $\mathrm{U}-234$ and $\mathrm{Pu}-238$. It is also an impurity in Thoria $\left(\mathrm{ThO}_{2}\right)$, the source material used for generating U-233. Based on the SRS Thoria specifications ${ }^{7}$, the concentration of Th-230 in Thoria is assumed to be a maximum of $1 \mathrm{ppm}$. Coupling this concentration with the mass concentration of Th-232 provides a basis for calculating the concentration of Th-230 introduced by the Thoria. In SB7b, this is the primary source of Th-230. The quantity of Th-230 produced by decay of U-234 and Pu-238 is determined by first backcalculating the concentrations of U-234 and Pu-238 when the waste was new and then performing decay/in-growth calculations to determine the quantity of Th-230 that "grows-in" over the 53 year time period. The total concentration of Th-230 in the waste is the sum of the Th-230 due to the Thoria impurities and the Th-230 produced through U-234 and Pu-238 decay. 


\subsection{RESULTS AND DISCUSSION}

\subsection{Summary of the Activities and Radionuclides for Input}

The complete list of radionuclides and their activities ${ }^{11}$, that were considered in the determination of reportable radionuclides are provided in Table 3-1. For those radionuclides with measured concentrations, the initial activities were calculated by using the weight percent reported for each radioisotope and its specific activity with the following equation: $A_{0}=M_{0} \times S p A$, where $A_{0}=$ Initial Activity, $\mathrm{M}_{\mathrm{o}}=$ mass in weight percent and $\mathrm{SpA}=$ specific activity of the isotope.

For each radionuclide listed in Table 3-1 there is an associated specific activity in units of $\mathrm{Ci} / \mathrm{g}$, wt $\%$ of total solids, activity in $\mu \mathrm{Ci} / \mathrm{g}$, activity in $\mathrm{Ci} / \mathrm{gal}$ and the method used to determine or estimate the value. The assay date for this data is May 24, 2012.

The total measured alpha activity of the digested samples was $<254 \mu \mathrm{Ci} / \mathrm{g}$ of total dried solids. Total measured beta activity was measured at $3.37 \mathrm{E}+04 \mu \mathrm{Ci} / \mathrm{g}$ of total dried solids. 
Table 3-1. List of Radionuclides and Activities Used as Input to the RadCalc v. 4.1 Program

\begin{tabular}{|c|c|c|c|c|c|}
\hline Radionuclide & $\begin{array}{l}\text { Specific Activity } \\
(\mathrm{Ci} / \mathrm{g})\end{array}$ & $\begin{array}{l}\text { Wt } \% \text { of Total } \\
\text { Solids }\end{array}$ & $\begin{array}{l}\text { Activity } \\
(\mu \mathrm{Ci} / \mathrm{g})^{t}\end{array}$ & $\begin{array}{r}\text { Activity } \\
\text { (Ci/gal) }\end{array}$ & Method \\
\hline $\mathrm{Cl}-36$ & $3.30 \mathrm{E}-02$ & $<1.23 \mathrm{E}-05$ & $<4.07 \mathrm{E}-03$ & $<2.68 \mathrm{E}-06$ & Cl-36 \\
\hline $\mathrm{Ni}-59$ & $8.08 \mathrm{E}-02$ & $3.18 \mathrm{E}-03$ & $2.57 \mathrm{E}+00$ & $1.69 \mathrm{E}-03$ & $\mathrm{Ni}-59 /-63$ \\
\hline Co-60 & $1.13 \mathrm{E}+03$ & $2.44 \mathrm{E}-07$ & $2.76 \mathrm{E}+00$ & $1.82 \mathrm{E}-03$ & Cs-Removed Gamma Counting \\
\hline $\mathrm{Ni}-63$ & $6.17 \mathrm{E}+01$ & $2.60 \mathrm{E}-04$ & $1.60 \mathrm{E}+02$ & $1.05 \mathrm{E}-01$ & $\mathrm{Ni}-59 /-63$ \\
\hline Se-79 & $6.97 \mathrm{E}-02$ & $2.21 \mathrm{E}-05$ & $1.54 \mathrm{E}-02$ & $1.02 \mathrm{E}-05$ & Se-79 \\
\hline Sr-90 & $1.36 \mathrm{E}+02$ & $9.30 \mathrm{E}-03$ & $1.27 \mathrm{E}+04$ & $8.35 \mathrm{E}+00$ & Sr-90 \\
\hline $\mathrm{Y}-90 *$ & $5.44 \mathrm{E}+05$ & $2.33 \mathrm{E}-06$ & $1.27 \mathrm{E}+04$ & $8.35 \mathrm{E}+00$ & Secular equilibrium w/ Sr-90 \\
\hline $\mathrm{Zr}-93$ & $2.51 \mathrm{E}-03$ & $1.84 \mathrm{E}-02$ & $4.63 \mathrm{E}-01$ & $3.05 \mathrm{E}-04$ & ICP-MS \\
\hline $\mathrm{Nb}-93 \mathrm{~m}$ & $2.83 \mathrm{E}+02$ & $1.49 \mathrm{E}-07$ & $4.21 \mathrm{E}-01$ & $2.77 \mathrm{E}-04$ & Calculated from Zr-93 and Waste Age \\
\hline Tc-99 & $1.70 \mathrm{E}-02$ & $5.70 \mathrm{E}-04$ & $9.67 \mathrm{E}-02$ & $6.37 \mathrm{E}-05$ & ICP-MS \\
\hline Pd-107 & $5.14 \mathrm{E}-04$ & $2.36 \mathrm{E}-04$ & $1.22 \mathrm{E}-03$ & $8.00 \mathrm{E}-07$ & Calculated from Pd-105 \\
\hline $\mathrm{Cd}-113 \mathrm{~m}$ & $2.17 \mathrm{E}+02$ & $1.54 \mathrm{E}-06$ & $3.33 \mathrm{E}+00$ & $2.19 \mathrm{E}-03$ & Based on Fission Yield \\
\hline $\mathrm{Sn}-121 \mathrm{~m}$ & $5.91 \mathrm{E}+01$ & 8.38E-07 & $4.95 \mathrm{E}-01$ & $3.26 \mathrm{E}-04$ & AD Sn-121m \\
\hline $\mathrm{Sb}-125$ & $1.03 \mathrm{E}+03$ & $<3.53 \mathrm{E}-08$ & $<3.64 \mathrm{E}-01$ & $<2.40 \mathrm{E}-04$ & Cs-Removed Gamma Counting \\
\hline $\mathrm{Te}-125 \mathrm{~m}^{*}$ & $1.80 \mathrm{E}+04$ & $<2.02 \mathrm{E}-09$ & $<3.64 \mathrm{E}-01$ & $<2.40 \mathrm{E}-04$ & Secular equilibrium w/ Sb-125 \\
\hline Sn-126 & $2.84 \mathrm{E}-02$ & $<2.48 \mathrm{E}-03$ & $<7.03 \mathrm{E}-01$ & $<4.63 \mathrm{E}-04$ & Cs-Removed Gamma Counting \\
\hline $\mathrm{I}-129$ & $1.77 \mathrm{E}-04$ & $6.03 \mathrm{E}-04$ & $1.06 \mathrm{E}-03$ & $6.59 \mathrm{E}-07$ & $\mathrm{I}-129$ \\
\hline Ba-133 & $2.50 \mathrm{E}+02$ & $<7.48 \mathrm{E}-08$ & $<1.87 \mathrm{E}-01$ & $<1.23 \mathrm{E}-04$ & Cs-Removed Gamma Counting \\
\hline Cs-135 & $1.15 \mathrm{E}-03$ & $2.88 \mathrm{E}-04$ & $3.32 \mathrm{E}-03$ & 2.18E-06 & ICP-MS \\
\hline Cs-137 & $8.70 \mathrm{E}+01$ & $7.41 \mathrm{E}-04$ & $6.44 \mathrm{E}+02$ & 4.24E-01 & Direct Gamma Counting \\
\hline Ba-137m* & $5.38 \mathrm{E}+08$ & $1.15 \mathrm{E}-10$ & $6.18 \mathrm{E}+02$ & 4.07E-01 & Secular equilibrium w/ Cs-137 \\
\hline Pm-147 & $9.27 \mathrm{E}+02$ & $<1.87 \mathrm{E}-05$ & $<1.73 \mathrm{E}+02$ & $<1.14 \mathrm{E}-01$ & Pm-147/Sm-151 \\
\hline Sm-151 & $2.63 \mathrm{E}+01$ & $9.39 \mathrm{E}-04$ & $2.47 \mathrm{E}+02$ & $1.63 \mathrm{E}-01$ & $\mathrm{Pm}-147 / \mathrm{Sm}-151$ \\
\hline Eu-154 & $2.70 \mathrm{E}+02$ & $5.15 \mathrm{E}-06$ & $1.39 \mathrm{E}+01$ & $9.15 \mathrm{E}-03$ & Cs-Removed Gamma Counting \\
\hline Eu-155 & $4.65 \mathrm{E}+02$ & $7.18 \mathrm{E}-07$ & $3.34 \mathrm{E}+00$ & $2.20 \mathrm{E}-03$ & Cs-Removed Gamma Counting \\
\hline $\mathrm{Pb}-210$ & $7.63 \mathrm{E}+01$ & $3.53 \mathrm{E}-12$ & $2.69 \mathrm{E}-06$ & $1.77 \mathrm{E}-09$ & $\begin{array}{l}\text { Calculated from Pu-238, U-234, Thoria } \\
\text { Impurity and Waste Age }\end{array}$ \\
\hline Ra-226 & $9.89 \mathrm{E}-01$ & $5.36 \mathrm{E}-10$ & $5.30 \mathrm{E}-06$ & $3.49 \mathrm{E}-09$ & $\begin{array}{l}\text { Calculated from Pu-238, U-234, Thoria } \\
\text { Impurity and Waste Age }\end{array}$ \\
\hline Ac-227 & $7.23 \mathrm{E}+01$ & $4.90 \mathrm{E}-13$ & $3.55 \mathrm{E}-07$ & $2.33 \mathrm{E}-10$ & Calculated from U-235 and Waste Age \\
\hline Th-229 & $2.13 \mathrm{E}-01$ & $9.92 \mathrm{E}-09$ & $2.11 \mathrm{E}-05$ & $1.39 \mathrm{E}-08$ & Calculated from U-233 and Waste Age \\
\hline Th-230 & $2.11 \mathrm{E}-02$ & $1.14 \mathrm{E}-06$ & $2.41 \mathrm{E}-04$ & $1.59 \mathrm{E}-07$ & $\begin{array}{l}\text { Calculated from Pu-238, U-234 } \\
\text { and Waste Age plus Thoria impurity }\end{array}$ \\
\hline $\mathrm{Pa}-231$ & 4.72E-02 & $1.45 \mathrm{E}-09$ & $6.86 \mathrm{E}-07$ & $4.51 \mathrm{E}-10$ & Calculated from U-235 and Waste Age \\
\hline Th-232 & $1.10 \mathrm{E}-07$ & $1.08 \mathrm{E}+00$ & $1.19 \mathrm{E}-03$ & $7.82 \mathrm{E}-07$ & ICP-MS \\
\hline $\mathrm{U}-233$ & $9.68 \mathrm{E}-03$ & $4.36 \mathrm{E}-04$ & $4.22 \mathrm{E}-02$ & $2.78 \mathrm{E}-05$ & ICP-MS \\
\hline U-234 & $6.25 \mathrm{E}-03$ & $6.49 \mathrm{E}-04$ & $4.06 \mathrm{E}-02$ & $2.67 \mathrm{E}-05$ & ICP-MS \\
\hline $\mathrm{U}-235$ & $2.16 \mathrm{E}-06$ & $2.83 \mathrm{E}-02$ & $6.12 \mathrm{E}-04$ & $4.03 \mathrm{E}-07$ & ICP-MS \\
\hline $\mathrm{U}-236$ & $6.47 \mathrm{E}-05$ & $1.40 \mathrm{E}-03$ & $9.03 \mathrm{E}-04$ & $5.94 \mathrm{E}-07$ & ICP-MS \\
\hline $\mathrm{Np}-237$ & $7.05 \mathrm{E}-04$ & $3.49 \mathrm{E}-03$ & $2.46 \mathrm{E}-02$ & $1.62 \mathrm{E}-05$ & ICP-MS \\
\hline U-238 & $3.36 \mathrm{E}-07$ & $4.75 \mathrm{E}+00$ & $1.60 \mathrm{E}-02$ & $1.05 \mathrm{E}-05$ & ICP-MS \\
\hline $\mathrm{Pu}-238$ & $1.71 \mathrm{E}+01$ & 8.32E-04 & $1.42 \mathrm{E}+02$ & $9.38 \mathrm{E}-02$ & $\mathrm{Pu}-238 /-241$ \\
\hline $\mathrm{Pu}-239$ & $6.22 \mathrm{E}-02$ & $1.73 \mathrm{E}-02$ & $1.08 \mathrm{E}+01$ & $7.08 \mathrm{E}-03$ & ICP-MS \\
\hline $\mathrm{Pu}-240$ & $2.28 \mathrm{E}-01$ & $1.57 \mathrm{E}-03$ & $3.59 \mathrm{E}+00$ & $2.36 \mathrm{E}-03$ & ICP-MS \\
\hline $\mathrm{Pu}-241$ & $1.03 \mathrm{E}+02$ & 4.94E-05 & $5.09 \mathrm{E}+01$ & $3.35 \mathrm{E}-02$ & $\mathrm{Pu}-238 /-241$ \\
\hline $\mathrm{Pu}-242$ & $3.82 \mathrm{E}-03$ & $<2.35 \mathrm{E}-04$ & $<8.98 \mathrm{E}-03$ & $<5.91 \mathrm{E}-06$ & ICP-MS \\
\hline Am-241 & $3.43 \mathrm{E}+00$ & $1.04 \mathrm{E}-03$ & $3.56 \mathrm{E}+01$ & $2.35 \mathrm{E}-02$ & Cs-Removed Gamma Counting \\
\hline Am-242m & $9.72 \mathrm{E}+00$ & $3.34 \mathrm{E}-07$ & $3.25 \mathrm{E}-02$ & $2.14 \mathrm{E}-05$ & $\mathrm{Am} / \mathrm{Cm}$ \\
\hline Am-243 & $1.99 \mathrm{E}-01$ & $2.50 \mathrm{E}-04$ & 4.99E-01 & $3.29 \mathrm{E}-04$ & $\mathrm{Am} / \mathrm{Cm}$ \\
\hline $\mathrm{Cm}-242$ & $3.31 \mathrm{E}+03$ & $8.11 \mathrm{E}-10$ & $2.68 \mathrm{E}-02$ & $1.76 \mathrm{E}-05$ & $\mathrm{Am} / \mathrm{Cm}$ \\
\hline $\mathrm{Cm}-243$ & $5.16 \mathrm{E}+01$ & $<5.60 \mathrm{E}-07$ & $<2.89 \mathrm{E}-01$ & $<1.90 \mathrm{E}-04$ & $\mathrm{Am} / \mathrm{Cm}$ \\
\hline $\mathrm{Cm}-244$ & $8.09 \mathrm{E}+01$ & $2.24 \mathrm{E}-05$ & $1.81 \mathrm{E}+01$ & 1.19E-02 & $\mathrm{Am} / \mathrm{Cm}$ \\
\hline $\mathrm{Cm}-245$ & $1.72 \mathrm{E}-01$ & $1.53 \mathrm{E}-06$ & $2.63 \mathrm{E}-03$ & $1.73 \mathrm{E}-06$ & $\mathrm{Am} / \mathrm{Cm}$ - ICP-MS \\
\hline $\mathrm{Cm}-246$ & $3.07 \mathrm{E}-01$ & $2.15 \mathrm{E}-06$ & $6.60 \mathrm{E}-03$ & $4.34 \mathrm{E}-06$ & $\mathrm{Am} / \mathrm{Cm}$ - ICP-MS \\
\hline $\mathrm{Cm}-247$ & $9.28 \mathrm{E}-05$ & $<3.50 \mathrm{E}-08$ & $<3.25 \mathrm{E}-08$ & $<2.14 \mathrm{E}-11$ & $\mathrm{Am} / \mathrm{Cm}$ - ICP-MS \\
\hline Bk-247 & $1.03 \mathrm{E}+00$ & $<3.52 \mathrm{E}-08$ & $<3.62 \mathrm{E}-04$ & $<2.38 \mathrm{E}-07$ & $\mathrm{Am} / \mathrm{Cm}$ - ICP-MS \\
\hline $\mathrm{Cm}-248$ & 4.25E-03 & $<2.89 \mathrm{E}-08$ & $<1.23 \mathrm{E}-06$ & $<8.09 \mathrm{E}-10$ & $\mathrm{Am} / \mathrm{Cm}$ - ICP-MS \\
\hline Cf-249 & $4.38 \mathrm{E}+00$ & $<5.37 \mathrm{E}-08$ & $<2.35 \mathrm{E}-03$ & $<1.55 \mathrm{E}-06$ & $\mathrm{Am} / \mathrm{Cm}$ \\
\hline Cf-250 & $1.09 \mathrm{E}+02$ & $<3.29 \mathrm{E}-11$ & $<3.59 \mathrm{E}-05$ & $<2.37 \mathrm{E}-08$ & $\mathrm{Am} / \mathrm{Cm}$ - ICP-MS \\
\hline $\mathrm{Cf}-251$ & $1.86 \mathrm{E}+00$ & $<2.75 \mathrm{E}-07$ & $<5.10 \mathrm{E}-03$ & $<3.36 \mathrm{E}-06$ & $\mathrm{Am} / \mathrm{Cm}$ \\
\hline $\mathrm{Cf}-252$ & $5.38 \mathrm{E}+02$ & $<3.88 \mathrm{E}-09$ & $<2.09 \mathrm{E}-02$ & $<1.38 \mathrm{E}-05$ & $\mathrm{Am} / \mathrm{Cm}$ \\
\hline
\end{tabular}

* Included because this isotope is in secular equilibrium with a parent for which a measured value was available.

${ }^{\mathrm{t}}$ Less than values represent the minimum detection limit value and hence are an upper bound for that isotope's activity. 


\subsection{Additional Radionuclides Requested}

The following radionuclides listed in Table 3-2 were not used in the WAPS radionuclide decay calculations, but are being reported as requested in the TTR.

Table 3-2. List of Additional Radionuclides and Activities Requested by DWPF in the TTR

\begin{tabular}{cccccl}
\hline Radionuclide & $\begin{array}{c}\text { Specific Activity } \\
(\mathbf{C i} / \mathbf{g})\end{array}$ & $\begin{array}{c}\text { Wt\% of } \\
\text { Total Solids }\end{array}$ & $\begin{array}{c}\text { Activity } \\
(\boldsymbol{\mu C i} / \mathbf{g})^{t}\end{array}$ & $\begin{array}{c}\text { Activity } \\
(\mathbf{C i} / \mathbf{g a l})\end{array}$ & \multicolumn{1}{c}{ Method } \\
\hline $\mathrm{Ru}-106$ & $3.35 \mathrm{E}+03$ & $<1.87 \mathrm{E}-08$ & $<6.26 \mathrm{E}-01$ & $<4.12 \mathrm{E}-04$ & Cs-Removed Gamma Counting \\
$\mathrm{Rh}-106 *$ & $3.56 \mathrm{E}+09$ & $<1.76 \mathrm{E}-14$ & $<6.26 \mathrm{E}-01$ & $<4.12 \mathrm{E}-04$ & *Secular equilibrium w/ Ru-106 \\
Cs-134 & $1.29 \mathrm{E}+03$ & $<2.11 \mathrm{E}-08$ & $<2.73 \mathrm{E}-01$ & $<1.79 \mathrm{E}-04$ & Gamma Counting \\
Ce-144 & $3.19 \mathrm{E}+03$ & $<4.31 \mathrm{E}-08$ & $<1.37 \mathrm{E}+00$ & $<9.04 \mathrm{E}-04$ & Cs-Removed Gamma Counting \\
Pr-144* & $7.56 \mathrm{E}+07$ & $<1.82 \mathrm{E}-12$ & $<1.37 \mathrm{E}+00$ & $<9.04 \mathrm{E}-04$ & *Secular equilibrium w/ Ce-144 \\
\hline
\end{tabular}

* Included because this isotope is in secular equilibrium with a parent for which a measured value was available.

${ }^{\mathrm{t}}$ Less than values represent the minimum detection limit value and hence are an upper bound for that isotope's activity.

\subsection{Identification of Reportable Radionuclides}

Based on radionuclides and activities provided in Table 3-1, a commercially available computer program, RadCalc v. $4.1^{16}$, was used to identify which radionuclides were reportable through calendar year 3115. The initial activities for 58 isotopes were entered into RadCalc v. 4.1 and the results of two calculations with the index years 2015 and 3115 (1100 years) are presented in Appendix A and Appendix L. Those radionuclides that are reportable are designated in these tables by a "yes". Additional calculations were performed for every 100 years up to 1100 years. These results are presented in Appendix B through K. Microsoft Excel spreadsheets were used to calculate the total activity in $\mu \mathrm{Ci} / \mathrm{g}$ of dried sludge solids at each time and the percent of the activity that each of the radionuclides contributed.

RadCalc v. 4.1 is a software application developed to assist the Department of Energy in performing calculations consistent with the requirements and methods prescribed by the Department of Energy, the U. S. Nuclear Regulatory Commission, the Environmental Protection Agency, and the International Commission of Radiation Protection ${ }^{17}$. Previous test cases using RadCalc v. 4.1 for SB7a WAPS were repeated for the current SB7b WAPS ${ }^{18}$. The calculations performed by RadCalc v. 4.1 were verified against a separate program called RadDecay ${ }^{\circledR}$ v. $4.01^{19}$. Comparisons between the two independent calculations are detailed in SRNL Electronic Notebook B9108-00026-02, "WAPS Data Shielded Cells" ${ }^{\prime 20}$. Certain radionuclides were identified in the RadCalc v. 4.1 calculations that were not present in the RadDecay ${ }^{\circledR}$ v. 4.01 calculation output. These are Sb-126m2, Hg-206, Tl-206, Tl-210, Bi-215, At215, At-219, Rn-217, Rn-218, and U-235m. All of these radionuclides have very short half-lives of minutes or less and only the Sb-126m2 and U-235m contributed significantly to the total activity. For instance at the year 3115 projection, the Sb- $126 \mathrm{~m} 2$ and $\mathrm{U}-235 \mathrm{~m}$ contributed $1.25 \%$ and $27.93 \%$ of the total activity, respectively.

The total Curie content of the dried sludge in the year 2015 is $2.56 \mathrm{E}+04 \mu \mathrm{Ci} / \mathrm{g}$. This value is greater than the $1.31 \mathrm{E}+04 \mu \mathrm{Ci} / \mathrm{g}$ total represented by the reportable radionuclides in Appendix A. The difference is due to the significant contribution to the activity from radionuclides having half-lives shorter than ten years. The activity of Y-90 accounts for nearly the entire difference, with the balance attributable primarily to $\mathrm{Ba}-137 \mathrm{~m}$.

Appendix L presents the reportable radionuclides indexed to the year 3115 . The total Curie content of the dried sludge in 3115 is $3.75 \mathrm{E}+01 \mu \mathrm{Ci} / \mathrm{g}$. This value is greater than the $2.52 \mathrm{E}+01 \mu \mathrm{Ci} / \mathrm{g}$ total 
represented by the radionuclides identified as reportable. The difference is due primarily to the contribution to the total activity from radionuclides having half-lives shorter than 10 years. These radionuclides include (in decreasing order of activity contribution): U-235m, Sb-126m, Sb-126m2, Np239, and Sb-126, Pa-233, Th-234, and Pa-234m.

Twenty-seven radionuclides have been identified as reportable for DWPF SB7b as specified by WAPS 1.2. Consistent with the strategy detailed in the WCP and WQR, each of these radionuclides has a halflife greater than 10 years and contributes more than $0.01 \%$ of the radioactivity on a Curie basis at some point from production through the 1100-year period between 2015 and 3115 . The 27 reportable radionuclides are given in Table 3-3. Examination of the calculations at every one hundred year interval out to 1100 years indicated two radionuclides became reportable at some point during this time period. Cd-113m became reportable at the initial 2015 interval, but was not reportable at any other future time. Sn-121m became reportable only in the year 2215. Previous transient reportability has been cited for $\mathrm{Am}-242 \mathrm{~m}^{23,24,25,26}$ and for $\mathrm{Cf}-249^{26}$. The data for these intermediate year calculations can be found in Appendices B-K.

Table 3-3. Reportable Radionuclides in DWPF Sludge Batch 7b

\begin{tabular}{cccccc}
\hline Cl-36* & Ni-59 & Ni-63 & Se-79 & Sr-90 & Zr-93 \\
Nb-93m & Tc-99 & Cd-113m & Sn-121m & Sn-126* & Cs-137 \\
Sm-151 & Th-229 & U-233 & U-234 & Np-237 & Pu-238 \\
U-238 & Pu-239 & Pu-240 & Am-241 & Pu-241 & Pu-242* \\
Am-243 & Cm-244 & Cm-246 & & & \\
\hline
\end{tabular}

* Based upon an analytical detection limit.

The WCP and WQR require that all of the radionuclides present in the Design Basis glass be considered as the initial set of reportable radionuclides. All of the radionuclides in the Design Basis glass are reportable except for three radionuclides: Pd-107, Cs-135, and Th-230. At no time during the 1100-year period between 2015 and 3115 did any of these three radionuclides contribute to more than $0.01 \%$ of the radioactivity on a Curie basis.

Two of the 27 reportable radionuclides for SB7b are not part of either the design-basis list of radionuclides $^{2}$ or the list of $\mathrm{Pu}$ and $\mathrm{U}$ isotopes identified in WAPS 1.6. These radionuclides are Th-229 and $\mathrm{Cm}-246$.

The list of reportable radionuclides that were determined for SB1B (MB2) ${ }^{21}$ contained two radionuclides that were not reportable for SB2 (MB3), SB3 (MB4), SB4 (MB5), or SB5 (MB6). These radionuclides were I-129 and Th-229. The I-129 continues to not be reportable for SB6 (MB7), SB7a (MB8) and now SB7b (MB9), whereas the Th-229 has been reportable for these last three sludge batches. Sn-121m was reportable for SB1B, SB2, and SB3, but due to an improved detection limit was not reportable for SB4 or SB5, it was reportable again for SB6, but then not reportable for SB7a. All previous values for SN$121 \mathrm{~m}$ have been detection limits, however a recent method improvement produced a detectable value for $\mathrm{Sn}-121 \mathrm{~m}$ for $\mathrm{Sb} 7 \mathrm{~b}$ and it is reportable again. Similarly, Cf-249 was reportable for SB3, but due to an improved detection limit for the input value, it was not reportable for SB4 through SB7b. Cm-247, Cm-248, and Bk-247 were reportable for SB4, but improved detection limits for these input values made all of them unreportable for SB5 and SB7a, but Cm-248 was reportable for SB6. None of these three radionuclides are reportable for SB7b. For earlier sludge batches and for SB6, SB7a and SB7b, the Se79 input value was not a detection limit value as it was for SB5. The detection limit was low enough in SB5 that the radionuclide was not reportable. C-14, reported in the first two batch analyses, has been 
excluded from consideration for future sludge batches ${ }^{8}$. For easier comparison, the reportable nuclides for SB1B, SB2, SB3, SB4, SB5, SB6, SB7a and SB7b have been reproduced in Table 3-4.

Table 3-4. Reportable Radionuclides in DWPF Sludge Batch 1B through 7b

\begin{tabular}{|c|c|c|c|c|c|c|c|c|}
\hline Isotope & $\begin{array}{c}\text { SB1B } \\
(\text { MB2) }\end{array}$ & $\begin{array}{c}\text { SB2 } \\
(\mathbf{M B 3})^{22}\end{array}$ & $\begin{array}{c}\text { SB3 } \\
(\text { MB4 })^{23}\end{array}$ & $\begin{array}{c}\text { SB4 } \\
\left(\text { MB5) }{ }^{24}\right.\end{array}$ & $\begin{array}{c}\text { SB 5 } \\
(\text { MB6) }\end{array}$ & $\begin{array}{c}\text { SB6 } \\
(\text { MB7 })^{26}\end{array}$ & $\begin{array}{c}\text { SB7a } \\
(\text { MB8 })^{7}\end{array}$ & $\begin{array}{c}\text { SB7b } \\
\text { (MB9) }\end{array}$ \\
\hline C-14 & $\mathrm{X}$ & $\mathrm{X}$ & & & & & & \\
\hline Cl-36 & & & & & $\mathrm{X}$ & & & $\mathrm{X}$ \\
\hline Ni-59 & $\mathrm{X}$ & $\mathrm{X}$ & $\mathrm{X}$ & X & $\mathrm{X}$ & $\mathrm{X}$ & $\mathrm{X}$ & $\mathrm{X}$ \\
\hline $\mathrm{Ni}-63$ & $\mathrm{X}$ & $\mathrm{X}$ & $\mathrm{X}$ & $\mathrm{X}$ & $\mathrm{X}$ & $\mathrm{X}$ & $\mathrm{X}$ & X \\
\hline Se-79 & $\mathrm{X}$ & X & X & $\mathrm{X}$ & & $\mathrm{X}$ & $\mathrm{X}$ & X \\
\hline Sr-90 & $\mathrm{X}$ & X & X & $\mathrm{X}$ & X & $\mathrm{X}$ & $\mathrm{X}$ & $\mathrm{X}$ \\
\hline Zr-93 & $\mathrm{X}$ & $\mathrm{X}$ & $\mathrm{X}$ & $\mathrm{X}$ & $\mathrm{X}$ & $\mathrm{X}$ & $\mathrm{X}$ & $\mathrm{X}$ \\
\hline Nb-93m & $\mathrm{X}$ & X & X & X & X & $\mathrm{X}$ & $\mathrm{X}$ & X \\
\hline Te-99 & $\mathrm{X}$ & X & $\mathrm{X}$ & X & X & $\mathrm{X}$ & $\mathrm{X}$ & $\mathrm{X}$ \\
\hline Cd-113m & & & & & & & & X \\
\hline Sn-121m & $\mathrm{X}$ & X & X & & & $\mathrm{X}$ & & X \\
\hline Sn-126 & $\mathrm{X}$ & X & $\mathrm{X}$ & $\mathrm{X}$ & X & $\mathrm{X}$ & $\mathrm{X}$ & $\mathrm{X}$ \\
\hline I-129 & $\mathrm{X}$ & & & & & & & \\
\hline Cs-137 & $\mathrm{X}$ & $\mathrm{X}$ & $X$ & $X$ & $\mathrm{X}$ & $\mathrm{X}$ & $\mathrm{X}$ & $\mathrm{X}$ \\
\hline Sm-151 & $\mathrm{X}$ & X & X & $\mathrm{X}$ & X & $\mathrm{X}$ & $\mathrm{X}$ & $\mathrm{X}$ \\
\hline Th-229 & $\mathrm{X}$ & & & & & $\mathrm{X}$ & $\mathrm{X}$ & $\mathrm{X}$ \\
\hline U-233 & $\mathrm{X}$ & $\mathrm{X}$ & $\mathrm{X}$ & $\mathrm{X}$ & $\mathrm{X}$ & $\mathrm{X}$ & $\mathrm{X}$ & $\mathrm{X}$ \\
\hline U-234 & $\mathrm{X}$ & X & X & $\mathrm{X}$ & X & $\mathrm{X}$ & $\mathrm{X}$ & $\mathrm{X}$ \\
\hline Np-237 & $\mathrm{X}$ & $\mathrm{X}$ & $\mathrm{X}$ & $\mathrm{X}$ & $\mathrm{X}$ & $\mathrm{X}$ & $\mathrm{X}$ & $\mathrm{X}$ \\
\hline U-238 & $\mathrm{X}$ & X & X & $\mathrm{X}$ & $\mathrm{X}$ & $\mathrm{X}$ & $\mathrm{X}$ & $\mathrm{X}$ \\
\hline Pu-238 & $\mathrm{X}$ & $\mathrm{X}$ & $\mathrm{X}$ & $\mathrm{X}$ & $\mathrm{X}$ & $\mathrm{X}$ & $\mathrm{X}$ & $\mathrm{X}$ \\
\hline Pu-239 & $\mathrm{X}$ & X & X & $\mathrm{X}$ & X & $\mathrm{X}$ & $\mathrm{X}$ & $\mathrm{X}$ \\
\hline Pu-240 & $\mathrm{X}$ & X & X & $\mathrm{X}$ & X & $\mathrm{X}$ & $\mathrm{X}$ & X \\
\hline Am-241 & $\mathrm{X}$ & X & $\mathrm{X}$ & $\mathrm{X}$ & X & $\mathrm{X}$ & $\mathrm{X}$ & X \\
\hline Pu-241 & $\mathrm{X}$ & $\mathrm{X}$ & X & $\mathrm{X}$ & $\mathrm{X}$ & $\mathrm{X}$ & $\mathrm{X}$ & $\mathrm{X}$ \\
\hline Pu-242 & $\mathrm{X}$ & $\mathrm{X}$ & $\mathrm{X}$ & $\mathrm{X}$ & $\mathrm{X}$ & $\mathrm{X}$ & $\mathrm{X}$ & $\mathrm{X}$ \\
\hline Am-242m & & & X & $\mathrm{X}$ & X & $\mathrm{X}$ & & \\
\hline Am-243 & $\mathrm{X}$ & $\mathrm{X}$ & X & $\mathrm{X}$ & $\mathrm{X}$ & $\mathrm{X}$ & $\mathrm{X}$ & $\mathrm{X}$ \\
\hline $\mathrm{Cm}-244$ & $\mathrm{X}$ & $\mathrm{X}$ & $\mathrm{X}$ & $\mathrm{X}$ & $\mathrm{X}$ & $\mathrm{X}$ & $\mathrm{X}$ & $\mathrm{X}$ \\
\hline Cm-245 & & X & $\mathrm{X}$ & $\mathrm{X}$ & X & $\mathrm{X}$ & & \\
\hline $\mathrm{Cm}-246$ & $\mathrm{X}$ & $\mathrm{X}$ & $\mathrm{X}$ & $\mathrm{X}$ & $\mathrm{X}$ & $\mathrm{X}$ & $\mathrm{X}$ & $\mathrm{X}$ \\
\hline Bk-247 & & & & $\mathrm{X}$ & & & & \\
\hline $\mathrm{Cm}-247$ & & & $\mathrm{X}$ & $X$ & & & & \\
\hline $\mathrm{Cm}-248$ & & & X & $\mathrm{X}$ & & X & & \\
\hline Cf-249 & & & X & & & $\mathrm{X}$ & & \\
\hline Cf-251 & & $\mathrm{X}$ & $X$ & $\mathrm{X}$ & $\mathrm{X}$ & $\mathrm{X}$ & $\mathrm{X}$ & \\
\hline
\end{tabular}

Reboul, S. H., Diprete, D. P., Click, D. R., Bannochie, C. J., Determination of Radionuclides in DWPF Sludge Batch $7 a$ (Macrobatch 8), SRNL-STI-2011-00720, Rev. 0, Savannah River Site, December, 2011.

21 Fellinger, T. L, Bibler, N. E., and Harbour, J. R., Characterization of and Waste Acceptance Radionuclides to be Reported for DWPF Macrobatch 2 (ESP 215 - ESP 221), WSRC-RP-99-00436, Revision 1, Savannah River Site, March 2004.

22 Bibler, N. E., DiPrete, D. P., and Harbour, J. R., Determination of Reportable Radionuclides for DWPF Sludge Batch 2 (Macrobatch 3), WSRC-TR-2002-00255, Revision 0, Savannah River Site, September 2002.

23 Bannochie, C. J. and Bibler, N. E., Determination of Reportable Radionuclides for DWPF Sludge Batch 3 (Macrobatch 4), WSRC-TR-2005-00157, Rev. 0, Savannah River Site, May 2005.

24 Bannochie, C. J., Bibler, N. E., and DiPrete, D. P., Determination of Reportable Radionuclides for DWPF Sludge Batch 4 (Macrobatch 5), WSRC-STI-2008-00142, Rev. 0, Savannah River Site, May 2008.

25 Bannochie, C. J., Bibler, N. E., and DiPrete, D. P., Determination of Reportable Radionuclides for DWPF Sludge Batch 5 (Macrobatch 6), SRNL-STI-2009-00821, Rev. 0, Savannah River Site, February 2010.

26 Bannochie, C. J. and DiPrete, D. P., Determination of Reportable Radionuclides for DWPF Sludge Batch 6 (Macrobatch 7), SRNL-STI-2011-00189, Rev. 0, Savannah River Site, May 2011. 


\subsection{The Ratio by Weight of $U$ and Pu Isotopes}

The WQR requires that the relative concentrations of the uranium and plutonium isotopes be provided from the analysis of each Macrobatch (in this case MB9 - Sludge Batch 7b) in order to meet the WAPS IAEA Safeguards Reporting for HLW Specification (WAPS 1.6). The data for uranium isotopes are given in Table 3-5.

Table 3-5. Uranium Isotope Distribution in DWPF Sludge Batch 7b

\begin{tabular}{ccc}
\hline Isotope & Wt\% Total Solids & Percent Distribution \\
\hline U-233 & $4.36 \mathrm{E}-04$ & 0.00912 \\
$\mathrm{U}-234$ & $6.49 \mathrm{E}-04$ & 0.0136 \\
$\mathrm{U}-235$ & $2.83 \mathrm{E}-02$ & 0.592 \\
$\mathrm{U}-236$ & $1.40 \mathrm{E}-03$ & 0.0292 \\
$\mathrm{U}-238$ & $4.75 \mathrm{E}+00$ & 99.4 \\
\hline Total & $4.78 \mathrm{E}+00$ & 100 \\
\hline
\end{tabular}

The data for the plutonium isotopes is given in Table 3-6.

Table 3-6. Plutonium Isotope Distribution in DWPF Sludge Batch 7b

\begin{tabular}{ccc}
\hline Isotope & Wt\% Total Solids & Percent Distribution \\
\hline $\mathrm{Pu}-238$ & $8.32 \mathrm{E}-04$ & 4.16 \\
$\mathrm{Pu}-239$ & $1.73 \mathrm{E}-02$ & 86.6 \\
$\mathrm{Pu}-240$ & $1.57 \mathrm{E}-03$ & 7.87 \\
$\mathrm{Pu}-241$ & $4.94 \mathrm{E}-05$ & 0.247 \\
$\mathrm{Pu}-242$ & $<2.35 \mathrm{E}-04$ & $<1.18$ \\
\hline Total & $2.00 \mathrm{E}-02$ & 100 \\
\hline
\end{tabular}

All of the Pu isotopes, as well as U-233, U-234, and U-238 are already reportable since they meet the requirement of having half-lives greater than 10 years and a contribution to the overall activity of greater than $0.01 \%$ on a Curie basis through the year 3115. In order to be compliant with WAPS 1.6, U-235 and U-236 also become reportable even though they contribute less than $0.01 \%$ to the total activity (U-235 at $0.002 \%$ and $U-236$ at $0.003 \%$ in 3115 ). 


\subsection{CONCLUSIONS}

Twenty-seven radionuclides have been identified as reportable for DWPF SB7b as specified by WAPS 1.2. Consistent with the strategy detailed in the WCP and WQR, each of these radionuclides has a halflife greater than ten years and contributes more than $0.01 \%$ of the radioactivity on a Curie basis at some point from production through the 1100 year period between 2015 and 3115 . The 27 reportable radionuclides are:

\begin{tabular}{cccccc}
\hline Cl-36* & Ni-59 & Ni-63 & Se-79 & Sr-90 & Zr-93 \\
Nb-93m & Tc-99 & Cd-113m & Sn-121m & Sn-126* & Cs-137 \\
Sm-151 & Th-229 & U-233 & U-234 & Np-237 & Pu-238 \\
U-238 & Pu-239 & Pu-240 & Am-241 & Pu-241 & Pu-242* \\
Am-243 & Cm-244 & Cm-246 & & & \\
\hline
\end{tabular}

* Based upon an analytical detection limit.

The WCP and WQR require that all of the radionuclides present in the Design Basis glass be considered as the initial set of reportable radionuclides. For SB7b, all of the radionuclides in the Design Basis glass are reportable except for three radionuclides: Pd-107, Cs-135, and Th-230. At no time during the 1100year period between 2015 and 3115 did any of these three radionuclides contribute to more than $0.01 \%$ of the radioactivity on a Curie basis.

Two additional uranium isotopes (U-235 and -236) must be added to the list of reportable radionuclides in order to meet WAPS 1.6. All of the Pu isotopes (Pu-238, -239, -240, -241, and -242) and other U isotopes (U-233, -234, and -238) identified in WAPS 1.6 were already determined to be reportable according to WAPS 1.2 This brings the total number of reportable radionuclides for SB7b to 29 . 


\subsection{RECOMMENDATIONS}

The radionuclide measurements made for SB7b are the most extensive conducted to date. Some method development/refinement occurred during the conduct of these measurements, leading to lower detection limits and more accurate measurement of some isotopes than was previously possible. Improvement in the analytical measurements will likely continue, and this in turn should lead to improved detection limit values for some radionuclides and actual measurements for still others. 


\subsection{REFERENCES}

1 Office of Environmental Management, Waste Acceptance Product Specifications for Vitrified HighLevel Waste Forms, USDOE Document DOE/EM-0093, Rev. 2, December 1996.

2 Savannah River Remediation, DWPF Waste Form Compliance Plan, WSRC-IM-91-116-0, Rev. 9, Savannah River Site, June 2012.

3 Washington Savannah River Company, DWPF Waste Form Qualification Report, Volume 4: Reporting the Radionuclide Inventory of the DWPF Product, WSRC-IM-91-116-4, Rev. 3, Savannah River Site, March 2006.

4 Bricker, J. M., Technical Task Request: Sludge Batch $7 b$ Qualification Studies, HLW-DWPF-TTR2011-0004, Rev. 0, Savannah River Site, December 2010

5 Pareizs, J. M., Task Technical and Quality Assurance Plan for Sludge Batch $7 B$ Qualification in the Shielded Cells, SRNL-RP-2011-00247, Rev. 0, Savannah River Site, February 2011.

6 Pareizs, J. M. and Click, D. R., Analytical Study Plan for Sludge Batch $7 b$ Qualification in the Shielded Cells, SRNL-RP-2011-00248, Rev. 0, Savannah River Site, March 2011.

7 Reboul, S. H., Diprete, D. P., Click, D. R., Bannochie, C. J., Determination of Radionuclides in DWPF Sludge Batch $7 a$ (Macrobatch 8), SRNL-STI-2011-00720, Rev. 0, Savannah River Site, December, 2011.

8 Bibler, N. E. and Fowler, J. R., Technical Basis for Eliminating Carbon-14 as a Reportable Radionuclide In DWPF Glass, WSRC-TR-2004-00629, Rev. 0, Savannah River Site, December 2004.

9 Hyder, M. L., Waste Acceptance Radionuclides to be Reported in Tank 51 Sludge Only Glass, WSRCTR-95-0485, Rev. 0, Savannah River Site, December 1995.

${ }^{10}$ Bannochie, C. J., Tank 40 Final SB7b Chemical Characterization Results, SRNL-STI-2012-00097, Rev. 1, Savannah River Site, November 2012.

11 Oak Ridge National Laboratory, Integrated Data Base Report-1996: U. S. Spent Nuclear Fuel and Radioactive Waste Inventories, Projections, and Characteristics, USDOE Document DOE/RW-0006, Rev. 13, Oak Ridge National Laboratory, December 1997.

${ }^{12}$ Friedlander, G. and Kennedy, J. W., Nuclear and Radiochemistry; John Wiley \& Sons, Inc: New York, 1957; p7.

${ }^{13}$ Baum, E. M., Knox, H. D., and Miller, T. R., Nuclides and Isotopes (Chart of the Nuclides), 16th Edition, KAPL, Inc. and Lockheed Martin, 2002.

${ }^{14}$ England, T. R. and Rider, B. F., ENDF-349, Evaluation and Compilation of Fission Product Yields, LA-UR-3106, Los Alamos National Laboratory, 1994. 
${ }^{15}$ Bibler, N. E., Fellinger, T. L., and Hobbs, D. T., Technetium-99 Behavior in Savannah River Site HLW Sludges During Waste Processing, WSRC-MS-2004-00614, Savannah River Site, Published as Paper No. 4 in Session 43 of WM'06 Proceedings, WM Symposium, Tucson, AZ, February 2006.

16 Radcalc, Version 4.1, U.S. Department of Energy Office of Packaging and Transportation, EnergySolutions Federal Services, Inc., Salt Lake City, UT 84101.

17 Reboul, S. H., Software Quality Assurance Plan for Using RadCalc 4.1 as a Radionuclide Decay and In-growth Calculator, Savannah River National Laboratory, B-SQP-A-0058, Rev. 0, October 2011.

${ }^{18}$ Crawford, C. L., Using RadCalc 4.1 as a Radionuclide Decay and In-Growth Calculator for SB7b Waste Acceptance Product Specifications, Savannah River National Laboratory, SRNL-L3100-201200170, Rev. 0, November 2012.

19 RadDecay, Version 4.01, Grove Software, Inc., Lynchburg, VA 24502.

${ }^{20}$ Crawford, C. L.,SRNL E-Notebook, B9108-00026-02, “WAPS Data Shielded Cells” (2012).

${ }^{21}$ Fellinger, T. L, Bibler, N. E., and Harbour, J. R., Characterization of and Waste Acceptance Radionuclides to be Reported for DWPF Macro Batch 2 (ESP 215 - ESP 221), WSRC-RP-99-00436, Rev. 1, Savannah River Site, March 2004.

${ }^{22}$ Bibler, N. E., DiPrete, D. P., and Harbour, J. R., Determination of Reportable Radionuclides for DWPF Sludge Batch 2 (Macro Batch 3), WSRC-TR-2002-00255, Rev. 0, Savannah River Site, September 2002.

${ }^{23}$ Bannochie, C. J. and Bibler, N. E., Determination of Reportable Radionuclides for DWPF Sludge Batch 3 (Macrobatch 4), WSRC-TR-2005-00157, Rev. 0, Savannah River Site, May 2005.

${ }^{24}$ Bannochie, C. J., Bibler, N. E., and DiPrete, D. P., Determination of Reportable Radionuclides for DWPF Sludge Batch 4 (Macrobatch 5), WSRC-STI-2008-00142, Rev. 0, Savannah River Site, May 2008.

${ }^{25}$ Bannochie, C. J., Bibler, N. E., and DiPrete, D. P., Determination of Reportable Radionuclides for DWPF Sludge Batch 5 (Macrobatch 6), SRNL-STI-2009-00821, Rev. 0, Savannah River Site, February 2010.

${ }^{26}$ Bannochie, C. J. and DiPrete, D. P., Determination of Reportable Radionuclides for DWPF Sludge Batch 6 (Macrobatch 7), SRNL-STI-2011-00189, Rev. 0, Savannah River Site, May 2011. 
APPENDIX A. ACTIVITIES OF DRIED SLUDGE IN YEAR $2015(\mu \mathrm{Ci} / \mathrm{g})$ 
SRNL-STI-2012-00294

Revision 0

\begin{tabular}{|c|c|c|c|}
\hline Nuclide & $\begin{array}{l}Y 2015 \\
\mu \mathrm{Ci} / \mathrm{g}\end{array}$ & $\begin{array}{c}\text { Fraction of } \\
\text { Activity }\end{array}$ & Reportable \\
\hline Ac-225 & $3.27 \mathrm{E}-05$ & $1.28 \mathrm{E}-09$ & \\
\hline Ac-227 & 3.87E-07 & $1.51 \mathrm{E}-11$ & \\
\hline Ac-228 & $3.61 \mathrm{E}-04$ & $1.41 \mathrm{E}-08$ & \\
\hline Am-241 & $3.57 \mathrm{E}+01$ & $1.39 \mathrm{E}-03$ & Yes \\
\hline Am-242 & $3.19 \mathrm{E}-02$ & $1.25 \mathrm{E}-06$ & \\
\hline $\mathrm{Am}-242 \mathrm{~m}$ & $3.20 \mathrm{E}-02$ & $1.25 \mathrm{E}-06$ & \\
\hline Am-243 & $4.99 \mathrm{E}-01$ & $1.95 \mathrm{E}-05$ & \\
\hline At-215 & $1.54 \mathrm{E}-12$ & $6.03 \mathrm{E}-17$ & \\
\hline At-217 & $3.27 \mathrm{E}-05$ & $1.28 \mathrm{E}-09$ & \\
\hline At-218 & $1.07 \mathrm{E}-09$ & 4.17E-14 & \\
\hline At-219 & $3.20 \mathrm{E}-13$ & $1.25 \mathrm{E}-17$ & \\
\hline Вa-133 & $1.54 \mathrm{E}-01$ & $6.00 \mathrm{E}-06$ & \\
\hline Ba-137m & $5.67 \mathrm{E}+02$ & $2.22 \mathrm{E}-02$ & \\
\hline Bi-209 & $2.85 \mathrm{E}-24$ & $1.11 \mathrm{E}-28$ & \\
\hline Bi-210 & $2.94 \mathrm{E}-06$ & $1.15 \mathrm{E}-10$ & \\
\hline $\mathrm{Bi}-211$ & $3.86 \mathrm{E}-07$ & $1.51 \mathrm{E}-11$ & \\
\hline $\mathrm{Bi}-212$ & $1.47 \mathrm{E}-04$ & $5.73 \mathrm{E}-09$ & \\
\hline Bi-213 & $3.27 \mathrm{E}-05$ & $1.28 \mathrm{E}-09$ & \\
\hline $\mathrm{Bi}-214$ & $5.62 \mathrm{E}-06$ & $2.20 \mathrm{E}-10$ & \\
\hline $\mathrm{Bi}-215$ & $3.11 \mathrm{E}-13$ & $1.22 \mathrm{E}-17$ & \\
\hline Bk-247 & $3.62 \mathrm{E}-04$ & $1.41 \mathrm{E}-08$ & \\
\hline Cd-113 & $1.17 \mathrm{E}-18$ & $4.58 \mathrm{E}-23$ & \\
\hline Cd-113m & $2.87 \mathrm{E}+00$ & $1.12 \mathrm{E}-04$ & Yes \\
\hline Cf-249 & $2.34 \mathrm{E}-03$ & $9.14 \mathrm{E}-08$ & \\
\hline Cf-250 & $3.06 \mathrm{E}-05$ & $1.20 \mathrm{E}-09$ & \\
\hline Cf- 251 & $5.09 \mathrm{E}-03$ & $1.99 \mathrm{E}-07$ & \\
\hline Cf- 252 & $9.52 \mathrm{E}-03$ & $3.72 \mathrm{E}-07$ & \\
\hline Cl-36 & $4.07 \mathrm{E}-03$ & $1.59 \mathrm{E}-07$ & \\
\hline $\mathrm{Cm}-242$ & $2.66 \mathrm{E}-02$ & $1.04 \mathrm{E}-06$ & \\
\hline $\mathrm{Cm}-243$ & $2.70 \mathrm{E}-01$ & $1.05 \mathrm{E}-05$ & \\
\hline $\mathrm{Cm}-244$ & $1.61 \mathrm{E}+01$ & $6.31 \mathrm{E}-04$ & Yes \\
\hline $\mathrm{Cm}-245$ & $2.63 \mathrm{E}-03$ & $1.03 \mathrm{E}-07$ & \\
\hline $\mathrm{Cm}-246$ & $6.60 \mathrm{E}-03$ & $2.58 \mathrm{E}-07$ & \\
\hline $\mathrm{Cm}-247$ & $3.32 \mathrm{E}-08$ & $1.30 \mathrm{E}-12$ & \\
\hline $\mathrm{Cm}-248$ & $1.32 \mathrm{E}-06$ & $5.15 \mathrm{E}-11$ & \\
\hline Co-60 & $1.86 \mathrm{E}+00$ & $7.27 \mathrm{E}-05$ & \\
\hline Cs-135 & $3.32 \mathrm{E}-03$ & $1.30 \mathrm{E}-07$ & \\
\hline Cs-137 & $6.01 \mathrm{E}+02$ & $2.35 \mathrm{E}-02$ & Yes \\
\hline Eu-154 & $1.09 \mathrm{E}+01$ & $4.27 \mathrm{E}-04$ & \\
\hline Eu-155 & $2.16 \mathrm{E}+00$ & $8.43 \mathrm{E}-05$ & \\
\hline Fr-221 & $3.27 \mathrm{E}-05$ & $1.28 \mathrm{E}-09$ & \\
\hline Fr-223 & $5.34 \mathrm{E}-09$ & $2.09 \mathrm{E}-13$ & \\
\hline Hg-206 & $5.60 \mathrm{E}-14$ & $2.19 \mathrm{E}-18$ & \\
\hline I-129 & $1.06 \mathrm{E}-03$ & $4.15 \mathrm{E}-08$ & \\
\hline Nb-93m & $4.25 \mathrm{E}-01$ & $1.66 \mathrm{E}-05$ & \\
\hline $\mathrm{Ni}-59$ & $2.57 \mathrm{E}+00$ & $1.01 \mathrm{E}-04$ & Yes \\
\hline Ni-63 & $1.57 \mathrm{E}+02$ & $6.13 \mathrm{E}-03$ & Yes \\
\hline Np-237 & $2.46 \mathrm{E}-02$ & $9.63 \mathrm{E}-07$ & \\
\hline Np-238 & $1.48 \mathrm{E}-04$ & $5.80 \mathrm{E}-09$ & \\
\hline Np-239 & 4.99E-01 & $1.95 \mathrm{E}-05$ & \\
\hline $\mathrm{Np}-240$ & $3.04 \mathrm{E}-14$ & $1.19 \mathrm{E}-18$ & \\
\hline $\mathrm{Pa}-231$ & $7.25 \mathrm{E}-07$ & $2.83 \mathrm{E}-11$ & \\
\hline $\mathrm{Pa}-233$ & $2.46 \mathrm{E}-02$ & $9.63 \mathrm{E}-07$ & \\
\hline $\mathrm{Pa}-234$ & $2.40 \mathrm{E}-05$ & $9.39 \mathrm{E}-10$ & \\
\hline $\mathrm{Pa}-234 \mathrm{~m}$ & $1.60 \mathrm{E}-02$ & $6.26 \mathrm{E}-07$ & \\
\hline Pb-209 & $3.27 \mathrm{E}-05$ & $1.28 \mathrm{E}-09$ & \\
\hline $\mathrm{Pb}-210$ & $2.95 \mathrm{E}-06$ & $1.15 \mathrm{E}-10$ & \\
\hline $\mathrm{Pb}-211$ & $3.86 \mathrm{E}-07$ & $1.51 \mathrm{E}-11$ & \\
\hline $\mathrm{Pb}-212$ & $1.47 \mathrm{E}-04$ & $5.73 \mathrm{E}-09$ & \\
\hline $\mathrm{Pb}-214$ & $5.62 \mathrm{E}-06$ & $2.20 \mathrm{E}-10$ & \\
\hline Pd-107 & $1.22 \mathrm{E}-03$ & 4.77E-08 & \\
\hline Pm-147 & $7.83 \mathrm{E}+01$ & $3.06 \mathrm{E}-03$ & \\
\hline Рo-210 & $2.89 \mathrm{E}-06$ & $1.13 \mathrm{E}-10$ & \\
\hline Po-211 & $1.05 \mathrm{E}-09$ & $4.12 \mathrm{E}-14$ & \\
\hline Po-212 & $9.39 \mathrm{E}-05$ & 3.67E-09 & \\
\hline Po-213 & $3.20 \mathrm{E}-05$ & $1.25 \mathrm{E}-09$ & \\
\hline Po-214 & $5.62 \mathrm{E}-06$ & $2.20 \mathrm{E}-10$ & \\
\hline
\end{tabular}

\begin{tabular}{|c|c|c|c|}
\hline Nuclide & $\begin{array}{l}\text { Y } 2015 \\
\mu \mathrm{Ci} / \mathrm{g}\end{array}$ & $\begin{array}{c}\text { Fraction of } \\
\text { Activity }\end{array}$ & Reportable \\
\hline Po-215 & $3.86 \mathrm{E}-07$ & $1.51 \mathrm{E}-11$ & \\
\hline Рo-216 & $1.47 \mathrm{E}-04$ & 5.74E-09 & \\
\hline Po-218 & $5.62 \mathrm{E}-06$ & $2.20 \mathrm{E}-10$ & \\
\hline Pu-238 & $1.39 \mathrm{E}+02$ & $5.42 \mathrm{E}-03$ & Yes \\
\hline $\mathrm{Pu}-239$ & $1.08 \mathrm{E}+01$ & $4.22 \mathrm{E}-04$ & Yes \\
\hline $\mathrm{Pu}-240$ & $3.59 \mathrm{E}+00$ & $1.41 \mathrm{E}-04$ & Yes \\
\hline Pu-241 & $4.40 \mathrm{E}+01$ & $1.72 \mathrm{E}-03$ & Yes \\
\hline $\mathrm{Pu}-242$ & $8.98 \mathrm{E}-03$ & $3.51 \mathrm{E}-07$ & \\
\hline $\mathrm{Pu}-243$ & $3.32 \mathrm{E}-08$ & $1.30 \mathrm{E}-12$ & \\
\hline $\mathrm{Pu}-244$ & $3.05 \mathrm{E}-14$ & $1.19 \mathrm{E}-18$ & \\
\hline $\mathrm{Ra}-223$ & $3.86 \mathrm{E}-07$ & $1.51 \mathrm{E}-11$ & \\
\hline Ra-224 & $1.47 \mathrm{E}-04$ & 5.74E-09 & \\
\hline Ra-225 & $3.28 \mathrm{E}-05$ & $1.28 \mathrm{E}-09$ & \\
\hline Ra-226 & $5.62 \mathrm{E}-06$ & $2.20 \mathrm{E}-10$ & \\
\hline Ra-228 & $3.61 \mathrm{E}-04$ & $1.41 \mathrm{E}-08$ & \\
\hline Rn-217 & 3.92E-09 & $1.53 \mathrm{E}-13$ & \\
\hline Rn-218 & $1.07 \mathrm{E}-12$ & 4.17E-17 & \\
\hline Rn-219 & $3.86 \mathrm{E}-07$ & $1.51 \mathrm{E}-11$ & \\
\hline Rn-220 & $1.47 \mathrm{E}-04$ & $5.74 \mathrm{E}-09$ & \\
\hline Rn-222 & $5.62 \mathrm{E}-06$ & $2.20 \mathrm{E}-10$ & \\
\hline Sb-125 & $1.71 \mathrm{E}-01$ & $6.70 \mathrm{E}-06$ & \\
\hline Sb-126 & $9.84 \mathrm{E}-02$ & $3.85 \mathrm{E}-06$ & \\
\hline $\mathrm{Sb}-126 \mathrm{~m}$ & 7.03E-01 & $2.75 \mathrm{E}-05$ & \\
\hline $\mathrm{Sb}-126 \mathrm{~m} 2$ & 4.71E-01 & $1.84 \mathrm{E}-05$ & \\
\hline $\mathrm{Se}-79$ & $1.54 \mathrm{E}-02$ & $6.02 \mathrm{E}-07$ & \\
\hline Sm-147 & 2.34E-09 & $9.17 \mathrm{E}-14$ & \\
\hline Sm-151 & $2.41 \mathrm{E}+02$ & 9.44E-03 & Yes \\
\hline Sn-121 & $3.70 \mathrm{E}-01$ & $1.45 \mathrm{E}-05$ & \\
\hline Sn-121m & $4.77 \mathrm{E}-01$ & $1.86 \mathrm{E}-05$ & \\
\hline Sn-126 & 7.03E-01 & $2.75 \mathrm{E}-05$ & \\
\hline Sr-90 & $1.18 \mathrm{E}+04$ & $4.62 \mathrm{E}-01$ & Yes \\
\hline Tc-99 & $9.67 \mathrm{E}-02$ & $3.78 \mathrm{E}-06$ & \\
\hline $\mathrm{Te}-125 \mathrm{~m}$ & 4.06E-02 & $1.59 \mathrm{E}-06$ & \\
\hline Th-227 & $3.81 \mathrm{E}-07$ & $1.49 \mathrm{E}-11$ & \\
\hline Th-228 & $1.48 \mathrm{E}-04$ & $5.78 \mathrm{E}-09$ & \\
\hline Th-229 & $3.31 \mathrm{E}-05$ & 1.29E-09 & \\
\hline Th-230 & $2.43 \mathrm{E}-04$ & $9.51 \mathrm{E}-09$ & \\
\hline Th-231 & $6.12 \mathrm{E}-04$ & $2.39 \mathrm{E}-08$ & \\
\hline Th-232 & $1.19 \mathrm{E}-03$ & $4.65 \mathrm{E}-08$ & \\
\hline Th-234 & $1.60 \mathrm{E}-02$ & $6.26 \mathrm{E}-07$ & \\
\hline Tl-206 & $3.94 \mathrm{E}-12$ & $1.54 \mathrm{E}-16$ & \\
\hline Tl-207 & $3.85 \mathrm{E}-07$ & $1.50 \mathrm{E}-11$ & \\
\hline Tl-208 & $5.27 \mathrm{E}-05$ & $2.06 \mathrm{E}-09$ & \\
\hline Tl-209 & $7.05 \mathrm{E}-07$ & $2.76 \mathrm{E}-11$ & \\
\hline Tl-210 & $1.18 \mathrm{E}-09$ & $4.61 \mathrm{E}-14$ & \\
\hline U-233 & $4.22 \mathrm{E}-02$ & $1.65 \mathrm{E}-06$ & \\
\hline U-234 & $4.18 \mathrm{E}-02$ & $1.63 \mathrm{E}-06$ & \\
\hline U-235 & $6.12 \mathrm{E}-04$ & 2.39E-08 & \\
\hline U-235m & $1.08 \mathrm{E}+01$ & 4.22E-04 & \\
\hline U-236 & $9.03 \mathrm{E}-04$ & 3.53E-08 & \\
\hline U-237 & $1.08 \mathrm{E}-03$ & $4.24 \mathrm{E}-08$ & \\
\hline U-238 & $1.60 \mathrm{E}-02$ & $6.26 \mathrm{E}-07$ & \\
\hline U-240 & 3.04E-14 & $1.19 \mathrm{E}-18$ & \\
\hline Y-90 & $1.18 \mathrm{E}+04$ & 4.62E-01 & \\
\hline Zr-93 & 4.63E-01 & $1.81 \mathrm{E}-05$ & \\
\hline TOTAL & $2.56 E+04$ & $1.00 \mathrm{E}+00$ & \\
\hline
\end{tabular}




\section{APPENDIX B. ACTIVITIES OF DRIED SLUDGE IN YEAR $2115(\mu \mathrm{Ci} / \mathrm{g})$}


SRNL-STI-2012-00294

Revision 0

\begin{tabular}{|c|c|c|c|}
\hline Nuclide & $\begin{array}{l}\text { Y } 2115 \\
\mu \mathrm{Ci} / \mathrm{g}\end{array}$ & $\begin{array}{c}\text { Fraction of } \\
\text { Activity }\end{array}$ & Reportable \\
\hline Ac-225 & $4.29 \mathrm{E}-04$ & $1.67 \mathrm{E}-07$ & \\
\hline Ac-227 & $1.62 \mathrm{E}-06$ & $6.30 \mathrm{E}-10$ & \\
\hline Ac- 228 & $1.19 \mathrm{E}-03$ & 4.64E-07 & \\
\hline Am-241 & $3.17 \mathrm{E}+01$ & $1.24 \mathrm{E}-02$ & Yes \\
\hline Am-242 & $1.95 \mathrm{E}-02$ & $7.61 \mathrm{E}-06$ & \\
\hline $\mathrm{Am}-242 \mathrm{~m}$ & $1.96 \mathrm{E}-02$ & $7.65 \mathrm{E}-06$ & \\
\hline Am-243 & 4.94E-01 & $1.93 \mathrm{E}-04$ & Yes \\
\hline At-215 & $6.45 \mathrm{E}-12$ & $2.52 \mathrm{E}-15$ & \\
\hline At-217 & $4.29 \mathrm{E}-04$ & $1.67 \mathrm{E}-07$ & \\
\hline At-218 & $3.18 \mathrm{E}-09$ & $1.24 \mathrm{E}-12$ & \\
\hline At-219 & $1.34 \mathrm{E}-12$ & $5.22 \mathrm{E}-16$ & \\
\hline Ba-133 & $2.14 \mathrm{E}-04$ & $8.34 \mathrm{E}-08$ & \\
\hline $\mathrm{Ba}-137 \mathrm{~m}$ & $5.65 \mathrm{E}+01$ & $2.20 \mathrm{E}-02$ & \\
\hline $\mathrm{Bi}-209$ & $8.46 \mathrm{E}-22$ & $3.30 \mathrm{E}-25$ & \\
\hline Bi-210 & $1.31 \mathrm{E}-05$ & $5.10 \mathrm{E}-09$ & \\
\hline Bi-211 & $1.61 \mathrm{E}-06$ & $6.30 \mathrm{E}-10$ & \\
\hline $\mathrm{Bi}-212$ & $1.19 \mathrm{E}-03$ & 4.64E-07 & \\
\hline Bi-213 & 4.29E-04 & $1.67 \mathrm{E}-07$ & \\
\hline $\mathrm{Bi}-214$ & $1.67 \mathrm{E}-05$ & $6.52 \mathrm{E}-09$ & \\
\hline $\mathrm{Bi}-215$ & $1.30 \mathrm{E}-12$ & $5.06 \mathrm{E}-16$ & \\
\hline Bk-247 & $3.44 \mathrm{E}-04$ & $1.34 \mathrm{E}-07$ & \\
\hline Cd-113 & $8.48 \mathrm{E}-18$ & $3.31 \mathrm{E}-21$ & \\
\hline Cd-113m & $2.11 \mathrm{E}-02$ & $8.22 \mathrm{E}-06$ & \\
\hline Cf-249 & $1.92 \mathrm{E}-03$ & $7.48 \mathrm{E}-07$ & \\
\hline Cf- 250 & $1.53 \mathrm{E}-07$ & $5.97 \mathrm{E}-11$ & \\
\hline Cf-251 & $4.71 \mathrm{E}-03$ & $1.84 \mathrm{E}-06$ & \\
\hline Cf- 252 & $3.96 \mathrm{E}-14$ & $1.55 \mathrm{E}-17$ & \\
\hline $\mathrm{Cl}-36$ & 4.07E-03 & $1.59 \mathrm{E}-06$ & \\
\hline $\mathrm{Cm}-242$ & $1.63 \mathrm{E}-02$ & $6.35 \mathrm{E}-06$ & \\
\hline $\mathrm{Cm}-243$ & $2.68 \mathrm{E}-02$ & $1.04 \mathrm{E}-05$ & \\
\hline $\mathrm{Cm}-244$ & $3.43 \mathrm{E}-01$ & $1.34 \mathrm{E}-04$ & Yes \\
\hline $\mathrm{Cm}-245$ & $2.63 \mathrm{E}-03$ & $1.02 \mathrm{E}-06$ & \\
\hline $\mathrm{Cm}-246$ & $6.50 \mathrm{E}-03$ & $2.54 \mathrm{E}-06$ & \\
\hline $\mathrm{Cm}-247$ & $5.44 \mathrm{E}-08$ & $2.12 \mathrm{E}-11$ & \\
\hline $\mathrm{Cm}-248$ & $1.39 \mathrm{E}-06$ & $5.41 \mathrm{E}-10$ & \\
\hline Co-60 & $3.62 \mathrm{E}-06$ & $1.41 \mathrm{E}-09$ & \\
\hline Cs- 135 & $3.32 \mathrm{E}-03$ & $1.30 \mathrm{E}-06$ & \\
\hline Cs-137 & $5.98 \mathrm{E}+01$ & $2.33 \mathrm{E}-02$ & Yes \\
\hline Eu-154 & $3.43 \mathrm{E}-03$ & $1.34 \mathrm{E}-06$ & \\
\hline Eu-155 & $1.00 \mathrm{E}-06$ & $3.91 \mathrm{E}-10$ & \\
\hline Fr-221 & 4.29E-04 & $1.67 \mathrm{E}-07$ & \\
\hline Fr-223 & $2.23 \mathrm{E}-08$ & $8.70 \mathrm{E}-12$ & \\
\hline Hg-206 & $2.49 \mathrm{E}-13$ & $9.70 \mathrm{E}-17$ & \\
\hline I-129 & $1.06 \mathrm{E}-03$ & 4.14E-07 & \\
\hline Nb-93m & $4.51 \mathrm{E}-01$ & $1.76 \mathrm{E}-04$ & Yes \\
\hline $\mathrm{Ni}-59$ & $2.57 \mathrm{E}+00$ & $1.00 \mathrm{E}-03$ & Yes \\
\hline Ni-63 & $7.87 \mathrm{E}+01$ & $3.07 \mathrm{E}-02$ & Yes \\
\hline Np-237 & $2.57 \mathrm{E}-02$ & $1.00 \mathrm{E}-05$ & \\
\hline Np-238 & $9.07 \mathrm{E}-05$ & $3.54 \mathrm{E}-08$ & \\
\hline $\mathrm{Np}-239$ & 4.94E-01 & $1.93 \mathrm{E}-04$ & \\
\hline $\mathrm{Np}-240$ & $1.13 \mathrm{E}-12$ & $4.41 \mathrm{E}-16$ & \\
\hline $\mathrm{Pa}-231$ & $2.02 \mathrm{E}-06$ & $7.88 \mathrm{E}-10$ & \\
\hline $\mathrm{Pa}-233$ & $2.57 \mathrm{E}-02$ & $1.00 \mathrm{E}-05$ & \\
\hline $\mathrm{Pa}-234$ & $2.40 \mathrm{E}-05$ & $9.37 \mathrm{E}-09$ & \\
\hline $\mathrm{Pa}-234 \mathrm{~m}$ & $1.60 \mathrm{E}-02$ & $6.24 \mathrm{E}-06$ & \\
\hline $\mathrm{Pb}-209$ & $4.29 \mathrm{E}-04$ & $1.67 \mathrm{E}-07$ & \\
\hline $\mathrm{Pb}-210$ & $1.31 \mathrm{E}-05$ & $5.10 \mathrm{E}-09$ & \\
\hline $\mathrm{Pb}-211$ & $1.61 \mathrm{E}-06$ & $6.30 \mathrm{E}-10$ & \\
\hline $\mathrm{Pb}-212$ & $1.19 \mathrm{E}-03$ & $4.64 \mathrm{E}-07$ & \\
\hline $\mathrm{Pb}-214$ & $1.67 \mathrm{E}-05$ & $6.52 \mathrm{E}-09$ & \\
\hline Pd-107 & $1.22 \mathrm{E}-03$ & $4.76 \mathrm{E}-07$ & \\
\hline
\end{tabular}

\begin{tabular}{|c|c|c|c|}
\hline Nuclide & $\begin{array}{l}\text { Y } 2115 \\
\mu \mathrm{Ci} / \mathrm{g}\end{array}$ & $\begin{array}{c}\text { Fraction of } \\
\text { Activity }\end{array}$ & Reportable \\
\hline Pm-147 & $2.63 \mathrm{E}-10$ & $1.02 \mathrm{E}-13$ & \\
\hline Po-210 & $1.30 \mathrm{E}-05$ & $5.08 \mathrm{E}-09$ & \\
\hline Po-211 & 4.40E-09 & $1.72 \mathrm{E}-12$ & \\
\hline Po-212 & 7.62E-04 & $2.98 \mathrm{E}-07$ & \\
\hline Po-213 & $4.20 \mathrm{E}-04$ & $1.64 \mathrm{E}-07$ & \\
\hline Po-214 & $1.67 \mathrm{E}-05$ & $6.52 \mathrm{E}-09$ & \\
\hline Po-215 & $1.61 \mathrm{E}-06$ & $6.30 \mathrm{E}-10$ & \\
\hline Po-216 & $1.19 \mathrm{E}-03$ & 4.64E-07 & \\
\hline Po-218 & $1.67 \mathrm{E}-05$ & $6.52 \mathrm{E}-09$ & \\
\hline $\mathrm{Pu}-238$ & $6.29 \mathrm{E}+01$ & $2.46 \mathrm{E}-02$ & Yes \\
\hline $\mathrm{Pu}-239$ & $1.08 \mathrm{E}+01$ & $4.20 \mathrm{E}-03$ & Yes \\
\hline $\mathrm{Pu}-240$ & $3.60 \mathrm{E}+00$ & $1.40 \mathrm{E}-03$ & Yes \\
\hline $\mathrm{Pu}-241$ & $3.52 \mathrm{E}-01$ & $1.37 \mathrm{E}-04$ & Yes \\
\hline $\mathrm{Pu}-242$ & $8.98 \mathrm{E}-03$ & $3.50 \mathrm{E}-06$ & \\
\hline $\mathrm{Pu}-243$ & $5.44 \mathrm{E}-08$ & $2.12 \mathrm{E}-11$ & \\
\hline $\mathrm{Pu}-244$ & $1.13 \mathrm{E}-12$ & $4.41 \mathrm{E}-16$ & \\
\hline $\mathrm{Ra}-223$ & $1.61 \mathrm{E}-06$ & $6.30 \mathrm{E}-10$ & \\
\hline $\mathrm{Ra}-224$ & $1.19 \mathrm{E}-03$ & 4.64E-07 & \\
\hline $\mathrm{Ra}-225$ & $4.29 \mathrm{E}-04$ & $1.67 \mathrm{E}-07$ & \\
\hline $\mathrm{Ra}-226$ & $1.67 \mathrm{E}-05$ & $6.53 \mathrm{E}-09$ & \\
\hline $\mathrm{Ra}-228$ & $1.19 \mathrm{E}-03$ & $4.64 \mathrm{E}-07$ & \\
\hline $\mathrm{Rn}-217$ & $5.15 \mathrm{E}-08$ & $2.01 \mathrm{E}-11$ & \\
\hline Rn-218 & $3.18 \mathrm{E}-12$ & $1.24 \mathrm{E}-15$ & \\
\hline Rn-219 & $1.61 \mathrm{E}-06$ & $6.30 \mathrm{E}-10$ & \\
\hline $\mathrm{Rn}-220$ & $1.19 \mathrm{E}-03$ & $4.64 \mathrm{E}-07$ & \\
\hline Rn-222 & $1.67 \mathrm{E}-05$ & $6.52 \mathrm{E}-09$ & \\
\hline Sb-125 & $2.10 \mathrm{E}-12$ & $8.18 \mathrm{E}-16$ & \\
\hline Sb-126 & $9.84 \mathrm{E}-02$ & $3.84 \mathrm{E}-05$ & \\
\hline $\mathrm{Sb}-126 \mathrm{~m}$ & $7.03 \mathrm{E}-01$ & $2.74 \mathrm{E}-04$ & \\
\hline $\mathrm{Sb}-126 \mathrm{~m} 2$ & $4.70 \mathrm{E}-01$ & $1.84 \mathrm{E}-04$ & \\
\hline Se-79 & $1.54 \mathrm{E}-02$ & $6.01 \mathrm{E}-06$ & \\
\hline Sm-147 & 4.28E-09 & $1.67 \mathrm{E}-12$ & \\
\hline Sm-151 & $1.12 \mathrm{E}+02$ & 4.36E- 02 & Yes \\
\hline Sn-121 & $1.05 \mathrm{E}-01$ & $4.09 \mathrm{E}-05$ & \\
\hline $\mathrm{Sn}-121 \mathrm{~m}$ & $1.35 \mathrm{E}-01$ & $5.28 \mathrm{E}-05$ & \\
\hline Sn-126 & $7.03 \mathrm{E}-01$ & $2.74 \mathrm{E}-04$ & Yes \\
\hline Sr-90 & $1.06 \mathrm{E}+03$ & $4.15 \mathrm{E}-01$ & Yes \\
\hline Tc-99 & 9.67E-02 & $3.77 \mathrm{E}-05$ & \\
\hline $\mathrm{Te}-125 \mathrm{~m}$ & $4.97 \mathrm{E}-13$ & $1.94 \mathrm{E}-16$ & \\
\hline Th-227 & $1.59 \mathrm{E}-06$ & $6.21 \mathrm{E}-10$ & \\
\hline Th-228 & $1.19 \mathrm{E}-03$ & 4.64E-07 & \\
\hline Th-229 & $4.29 \mathrm{E}-04$ & $1.68 \mathrm{E}-07$ & \\
\hline Th-230 & $2.95 \mathrm{E}-04$ & $1.15 \mathrm{E}-07$ & \\
\hline Th-231 & $6.13 \mathrm{E}-04$ & 2.39E-07 & \\
\hline Th-232 & $1.19 \mathrm{E}-03$ & $4.64 \mathrm{E}-07$ & \\
\hline Th-234 & $1.60 \mathrm{E}-02$ & $6.24 \mathrm{E}-06$ & \\
\hline Tl-206 & $1.75 \mathrm{E}-11$ & $6.83 \mathrm{E}-15$ & \\
\hline Tl-207 & $1.61 \mathrm{E}-06$ & $6.28 \mathrm{E}-10$ & \\
\hline Tl-208 & $4.28 \mathrm{E}-04$ & $1.67 \mathrm{E}-07$ & \\
\hline Tl-209 & $9.26 \mathrm{E}-06$ & $3.62 \mathrm{E}-09$ & \\
\hline Tl-210 & $3.51 \mathrm{E}-09$ & $1.37 \mathrm{E}-12$ & \\
\hline U-233 & $4.22 \mathrm{E}-02$ & $1.65 \mathrm{E}-05$ & \\
\hline U-234 & $6.88 \mathrm{E}-02$ & $2.69 \mathrm{E}-05$ & \\
\hline U-235 & $6.13 \mathrm{E}-04$ & $2.39 \mathrm{E}-07$ & \\
\hline U-235m & $1.08 \mathrm{E}+01$ & $4.20 \mathrm{E}-03$ & \\
\hline U-236 & $9.14 \mathrm{E}-04$ & $3.57 \mathrm{E}-07$ & \\
\hline U-237 & $8.67 \mathrm{E}-06$ & $3.38 \mathrm{E}-09$ & \\
\hline U-238 & $1.60 \mathrm{E}-02$ & $6.24 \mathrm{E}-06$ & \\
\hline U-240 & $1.13 \mathrm{E}-12$ & $4.41 \mathrm{E}-16$ & \\
\hline Y-90 & $1.06 \mathrm{E}+03$ & $4.15 \mathrm{E}-01$ & \\
\hline Zr-93 & 4.63E-01 & $1.81 \mathrm{E}-04$ & Yes \\
\hline TOTAL & $2.56 \mathrm{E}+03$ & $1.00 \mathrm{E}+00$ & \\
\hline
\end{tabular}


SRNL-STI-2012-00294

Revision 0

\begin{tabular}{|c|c|c|c|}
\hline Nuclide & $\begin{array}{l}\text { Y } 2215 \\
\mu \mathrm{Ci} / \mathrm{g}\end{array}$ & $\begin{array}{c}\text { Fraction of } \\
\text { Activity }\end{array}$ & Reportable \\
\hline Ac-225 & $8.21 \mathrm{E}-04$ & $2.15 \mathrm{E}-06$ & \\
\hline Ac-227 & $2.91 \mathrm{E}-06$ & $7.61 \mathrm{E}-09$ & \\
\hline Ac- 228 & $1.19 \mathrm{E}-03$ & $3.12 \mathrm{E}-06$ & \\
\hline Am-241 & $2.70 \mathrm{E}+01$ & 7.06E-02 & Yes \\
\hline Am-242 & $1.19 \mathrm{E}-02$ & $3.12 \mathrm{E}-05$ & \\
\hline Am- $242 m$ & $1.20 \mathrm{E}-02$ & $3.14 \mathrm{E}-05$ & \\
\hline Am-243 & $4.90 \mathrm{E}-01$ & $1.28 \mathrm{E}-03$ & Yes \\
\hline At-215 & $1.16 \mathrm{E}-11$ & $3.04 \mathrm{E}-14$ & \\
\hline At-217 & $8.21 \mathrm{E}-04$ & $2.15 \mathrm{E}-06$ & \\
\hline At-218 & 5.69E-09 & $1.49 \mathrm{E}-11$ & \\
\hline At-219 & $2.41 \mathrm{E}-12$ & $6.30 \mathrm{E}-15$ & \\
\hline Ba-133 & $2.98 \mathrm{E}-07$ & $7.80 \mathrm{E}-10$ & \\
\hline Ba-137m & $5.62 \mathrm{E}+00$ & $1.47 \mathrm{E}-02$ & \\
\hline Bi-209 & $3.13 \mathrm{E}-21$ & $8.19 \mathrm{E}-24$ & \\
\hline Bi-210 & $2.56 \mathrm{E}-05$ & $6.70 \mathrm{E}-08$ & \\
\hline Bi-211 & $2.90 \mathrm{E}-06$ & 7.60E-09 & \\
\hline Bi-212 & 1.19E-03 & $3.12 \mathrm{E}-06$ & \\
\hline Bi-213 & $8.21 \mathrm{E}-04$ & $2.15 \mathrm{E}-06$ & \\
\hline Bi-214 & $3.00 \mathrm{E}-05$ & $7.85 \mathrm{E}-08$ & \\
\hline $\mathrm{Bi}-215$ & $2.33 \mathrm{E}-12$ & $6.11 \mathrm{E}-15$ & \\
\hline Bk-247 & $3.27 \mathrm{E}-04$ & 8.56E-07 & \\
\hline Cd-113 & $8.54 \mathrm{E}-18$ & $2.24 \mathrm{E}-20$ & \\
\hline Cd-113m & $1.54 \mathrm{E}-04$ & 4.04E-07 & \\
\hline Cf-249 & $1.57 \mathrm{E}-03$ & $4.12 \mathrm{E}-06$ & \\
\hline Cf- 250 & $7.64 \mathrm{E}-10$ & $2.00 \mathrm{E}-12$ & \\
\hline Cf-251 & $4.36 \mathrm{E}-03$ & $1.14 \mathrm{E}-05$ & \\
\hline Cf- 252 & $1.65 \mathrm{E}-25$ & $4.32 \mathrm{E}-28$ & \\
\hline $\mathrm{Cl}-36$ & $4.07 \mathrm{E}-03$ & $1.07 \mathrm{E}-05$ & \\
\hline $\mathrm{Cm}-242$ & $9.95 \mathrm{E}-03$ & $2.61 \mathrm{E}-05$ & \\
\hline $\mathrm{Cm}-243$ & $2.66 \mathrm{E}-03$ & $6.95 \mathrm{E}-06$ & \\
\hline $\mathrm{Cm}-244$ & $7.29 \mathrm{E}-03$ & $1.91 \mathrm{E}-05$ & \\
\hline $\mathrm{Cm}-245$ & $2.62 \mathrm{E}-03$ & $6.86 \mathrm{E}-06$ & \\
\hline $\mathrm{Cm}-246$ & $6.41 \mathrm{E}-03$ & $1.68 \mathrm{E}-05$ & \\
\hline $\mathrm{Cm}-247$ & 7.40E-08 & $1.94 \mathrm{E}-10$ & \\
\hline $\mathrm{Cm}-248$ & $1.39 \mathrm{E}-06$ & 3.63E-09 & \\
\hline Co-60 & $7.04 \mathrm{E}-12$ & $1.84 \mathrm{E}-14$ & \\
\hline Cs- 135 & $3.32 \mathrm{E}-03$ & $8.69 \mathrm{E}-06$ & \\
\hline Cs-137 & $5.95 \mathrm{E}+00$ & $1.56 \mathrm{E}-02$ & Yes \\
\hline Eu-154 & $1.08 \mathrm{E}-06$ & $2.81 \mathrm{E}-09$ & \\
\hline Eu-155 & $4.64 \mathrm{E}-13$ & $1.22 \mathrm{E}-15$ & \\
\hline Fr-221 & $8.21 \mathrm{E}-04$ & $2.15 \mathrm{E}-06$ & \\
\hline Fr-223 & $4.01 \mathrm{E}-08$ & $1.05 \mathrm{E}-10$ & \\
\hline $\mathrm{Hg}-206$ & $4.86 \mathrm{E}-13$ & $1.27 \mathrm{E}-15$ & \\
\hline I-129 & $1.06 \mathrm{E}-03$ & $2.78 \mathrm{E}-06$ & \\
\hline $\mathrm{Nb}-93 \mathrm{~m}$ & $4.51 \mathrm{E}-01$ & $1.18 \mathrm{E}-03$ & Yes \\
\hline $\mathrm{Ni}-59$ & $2.57 \mathrm{E}+00$ & $6.72 \mathrm{E}-03$ & Yes \\
\hline $\mathrm{Ni}-63$ & $3.95 \mathrm{E}+01$ & $1.03 \mathrm{E}-01$ & Yes \\
\hline Np-237 & $2.67 \mathrm{E}-02$ & $6.99 \mathrm{E}-05$ & \\
\hline Np-238 & $5.55 \mathrm{E}-05$ & $1.45 \mathrm{E}-07$ & \\
\hline Np-239 & $4.90 \mathrm{E}-01$ & $1.28 \mathrm{E}-03$ & \\
\hline Np-240 & $2.23 \mathrm{E}-12$ & $5.84 \mathrm{E}-15$ & \\
\hline $\mathrm{Pa}-231$ & $3.31 \mathrm{E}-06$ & 8.67E-09 & \\
\hline $\mathrm{Pa}-233$ & $2.67 \mathrm{E}-02$ & $6.99 \mathrm{E}-05$ & \\
\hline $\mathrm{Pa}-234$ & $2.40 \mathrm{E}-05$ & $6.28 \mathrm{E}-08$ & \\
\hline $\mathrm{Pa}-234 \mathrm{~m}$ & $1.60 \mathrm{E}-02$ & 4.19E-05 & \\
\hline Pb-209 & $8.21 \mathrm{E}-04$ & $2.15 \mathrm{E}-06$ & \\
\hline $\mathrm{Pb}-210$ & $2.56 \mathrm{E}-05$ & $6.70 \mathrm{E}-08$ & \\
\hline $\mathrm{Pb}-211$ & $2.90 \mathrm{E}-06$ & 7.60E-09 & \\
\hline $\mathrm{Pb}-212$ & $1.19 \mathrm{E}-03$ & $3.12 \mathrm{E}-06$ & \\
\hline $\mathrm{Pb}-214$ & $3.00 \mathrm{E}-05$ & $7.85 \mathrm{E}-08$ & \\
\hline
\end{tabular}

\begin{tabular}{|c|c|c|c|}
\hline Nuclide & $\begin{array}{l}\text { Y } 2215 \\
\mu \mathrm{Ci} / \mathrm{g}\end{array}$ & $\begin{array}{c}\text { Fraction of } \\
\text { Activity }\end{array}$ & Reportable \\
\hline Pd-107 & $1.22 \mathrm{E}-03$ & $3.19 \mathrm{E}-06$ & \\
\hline Pm-147 & $8.81 \mathrm{E}-22$ & $2.31 \mathrm{E}-24$ & \\
\hline Po-210 & $2.55 \mathrm{E}-05$ & $6.68 \mathrm{E}-08$ & \\
\hline Po-211 & 7.93E-09 & $2.08 \mathrm{E}-11$ & \\
\hline Po-212 & $7.62 \mathrm{E}-04$ & $2.00 \mathrm{E}-06$ & \\
\hline Po-213 & $8.04 \mathrm{E}-04$ & $2.10 \mathrm{E}-06$ & \\
\hline Po-214 & $3.00 \mathrm{E}-05$ & $7.85 \mathrm{E}-08$ & \\
\hline Po-215 & $2.90 \mathrm{E}-06$ & $7.60 \mathrm{E}-09$ & \\
\hline Po-216 & $1.19 \mathrm{E}-03$ & $3.12 \mathrm{E}-06$ & \\
\hline Po-218 & $3.00 \mathrm{E}-05$ & $7.85 \mathrm{E}-08$ & \\
\hline $\mathrm{Pu}-238$ & $2.86 \mathrm{E}+01$ & $7.48 \mathrm{E}-02$ & Yes \\
\hline $\mathrm{Pu}-239$ & $1.07 \mathrm{E}+01$ & $2.81 \mathrm{E}-02$ & Yes \\
\hline $\mathrm{Pu}-240$ & $3.56 \mathrm{E}+00$ & $9.33 \mathrm{E}-03$ & Yes \\
\hline $\mathrm{Pu}-241$ & $5.39 \mathrm{E}-03$ & $1.41 \mathrm{E}-05$ & \\
\hline $\mathrm{Pu}-242$ & $8.98 \mathrm{E}-03$ & $2.35 \mathrm{E}-05$ & \\
\hline $\mathrm{Pu}-243$ & 7.40E-08 & $1.94 \mathrm{E}-10$ & \\
\hline $\mathrm{Pu}-244$ & $2.23 \mathrm{E}-12$ & $5.85 \mathrm{E}-15$ & \\
\hline $\mathrm{Ra}-223$ & $2.90 \mathrm{E}-06$ & 7.60E-09 & \\
\hline $\mathrm{Ra}-224$ & $1.19 \mathrm{E}-03$ & $3.12 \mathrm{E}-06$ & \\
\hline $\mathrm{Ra}-225$ & $8.22 \mathrm{E}-04$ & $2.15 \mathrm{E}-06$ & \\
\hline $\mathrm{Ra}-226$ & $3.00 \mathrm{E}-05$ & $7.85 \mathrm{E}-08$ & \\
\hline $\mathrm{Ra}-228$ & $1.19 \mathrm{E}-03$ & $3.12 \mathrm{E}-06$ & \\
\hline Rn-217 & $9.86 \mathrm{E}-08$ & $2.58 \mathrm{E}-10$ & \\
\hline $\mathrm{Rn}-218$ & $5.69 \mathrm{E}-12$ & $1.49 \mathrm{E}-14$ & \\
\hline Rn-219 & $2.90 \mathrm{E}-06$ & 7.60E-09 & \\
\hline $\mathrm{Rn}-220$ & $1.19 \mathrm{E}-03$ & $3.12 \mathrm{E}-06$ & \\
\hline Rn-222 & $3.00 \mathrm{E}-05$ & $7.85 \mathrm{E}-08$ & \\
\hline Sb-125 & $2.56 \mathrm{E}-23$ & $6.71 \mathrm{E}-26$ & \\
\hline Sb-126 & $9.84 \mathrm{E}-02$ & $2.58 \mathrm{E}-04$ & \\
\hline Sb-126m & 7.03E-01 & $1.84 \mathrm{E}-03$ & \\
\hline $\mathrm{Sb}-126 \mathrm{~m} 2$ & $4.70 \mathrm{E}-01$ & $1.23 \mathrm{E}-03$ & \\
\hline Se-79 & $1.54 \mathrm{E}-02$ & $4.03 \mathrm{E}-05$ & \\
\hline Sm-147 & $4.28 \mathrm{E}-09$ & $1.12 \mathrm{E}-11$ & \\
\hline Sm-151 & $5.17 \mathrm{E}+01$ & $1.35 \mathrm{E}-01$ & Yes \\
\hline Sn- 121 & $2.98 \mathrm{E}-02$ & 7.79E-05 & \\
\hline Sn-121m & $3.83 \mathrm{E}-02$ & $1.00 \mathrm{E}-04$ & Yes \\
\hline Sn-126 & 7.03E-01 & $1.84 \mathrm{E}-03$ & Yes \\
\hline Sr- 90 & $9.58 \mathrm{E}+01$ & $2.51 \mathrm{E}-01$ & Yes \\
\hline Tc-99 & $9.66 \mathrm{E}-02$ & $2.53 \mathrm{E}-04$ & Yes \\
\hline $\mathrm{Te}-125 \mathrm{~m}$ & $6.08 \mathrm{E}-24$ & $1.59 \mathrm{E}-26$ & \\
\hline Th-227 & $2.86 \mathrm{E}-06$ & $7.50 \mathrm{E}-09$ & \\
\hline Th-228 & $1.19 \mathrm{E}-03$ & $3.12 \mathrm{E}-06$ & \\
\hline Th-229 & $8.22 \mathrm{E}-04$ & $2.15 \mathrm{E}-06$ & \\
\hline Th-230 & $3.65 \mathrm{E}-04$ & $9.55 \mathrm{E}-07$ & \\
\hline Th-231 & $6.14 \mathrm{E}-04$ & $1.61 \mathrm{E}-06$ & \\
\hline Th-232 & $1.19 \mathrm{E}-03$ & $3.12 \mathrm{E}-06$ & \\
\hline Th-234 & $1.60 \mathrm{E}-02$ & 4.19E-05 & \\
\hline Tl-206 & $3.43 \mathrm{E}-11$ & $8.97 \mathrm{E}-14$ & \\
\hline Tl-207 & $2.90 \mathrm{E}-06$ & $7.58 \mathrm{E}-09$ & \\
\hline Tl-208 & $4.28 \mathrm{E}-04$ & $1.12 \mathrm{E}-06$ & \\
\hline Tl-209 & $1.77 \mathrm{E}-05$ & $4.65 \mathrm{E}-08$ & \\
\hline Tl-210 & $6.29 \mathrm{E}-09$ & $1.65 \mathrm{E}-11$ & \\
\hline U-233 & $4.22 \mathrm{E}-02$ & $1.10 \mathrm{E}-04$ & Yes \\
\hline U-234 & $8.11 \mathrm{E}-02$ & $2.12 \mathrm{E}-04$ & Yes \\
\hline U-235 & $6.14 \mathrm{E}-04$ & $1.61 \mathrm{E}-06$ & \\
\hline U-235m & $1.07 \mathrm{E}+01$ & $2.81 \mathrm{E}-02$ & \\
\hline U-236 & $9.24 \mathrm{E}-04$ & $2.42 \mathrm{E}-06$ & \\
\hline U-237 & $1.33 \mathrm{E}-07$ & $3.47 \mathrm{E}-10$ & \\
\hline U-238 & $1.60 \mathrm{E}-02$ & 4.19E-05 & \\
\hline U-240 & $2.23 \mathrm{E}-12$ & $5.84 \mathrm{E}-15$ & \\
\hline Y-90 & $9.58 \mathrm{E}+01$ & $2.51 \mathrm{E}-01$ & \\
\hline Zr-93 & $4.63 \mathrm{E}-01$ & $1.21 \mathrm{E}-03$ & Yes \\
\hline TOTAL & $3.82 \mathrm{E}+02$ & $1.00 \mathrm{E}+00$ & \\
\hline
\end{tabular}


SRNL-STI-2012-00294

Revision 0

\begin{tabular}{|c|c|c|c|}
\hline Nuclide & $\begin{array}{l}\text { Y } 2315 \\
\mu \mathrm{Ci} / \mathrm{g}\end{array}$ & $\begin{array}{c}\text { Fraction of } \\
\text { Activity }\end{array}$ & Reportable \\
\hline Ac-225 & $1.21 \mathrm{E}-03$ & $9.31 \mathrm{E}-06$ & \\
\hline Ac-227 & $4.20 \mathrm{E}-06$ & 3.23E-08 & \\
\hline Ac-228 & 1.19E-03 & $9.16 \mathrm{E}-06$ & \\
\hline Am-241 & $2.30 \mathrm{E}+01$ & $1.77 \mathrm{E}-01$ & Yes \\
\hline Am-242 & $7.30 \mathrm{E}-03$ & 5.61E-05 & \\
\hline Am-242m & 7.33E-03 & $5.64 \mathrm{E}-05$ & \\
\hline Am-243 & $4.85 \mathrm{E}-01$ & $3.73 \mathrm{E}-03$ & Yes \\
\hline At-215 & $1.68 \mathrm{E}-11$ & $1.29 \mathrm{E}-13$ & \\
\hline At-217 & $1.21 \mathrm{E}-03$ & $9.31 \mathrm{E}-06$ & \\
\hline At-218 & 8.70E-09 & 6.69E-11 & \\
\hline At-219 & $3.48 \mathrm{E}-12$ & $2.67 \mathrm{E}-14$ & \\
\hline Ba-133 & $4.15 \mathrm{E}-10$ & $3.19 \mathrm{E}-12$ & \\
\hline $\mathrm{Ba}-137 \mathrm{~m}$ & 5.59E-01 & 4.30E-03 & \\
\hline Bi-209 & $6.84 \mathrm{E}-21$ & $5.26 \mathrm{E}-23$ & \\
\hline Bi-210 & $4.06 \mathrm{E}-05$ & $3.12 \mathrm{E}-07$ & \\
\hline Bi-211 & $4.20 \mathrm{E}-06$ & $3.23 \mathrm{E}-08$ & \\
\hline Bi-212 & $1.19 \mathrm{E}-03$ & $9.16 \mathrm{E}-06$ & \\
\hline Bi-213 & $1.21 \mathrm{E}-03$ & $9.31 \mathrm{E}-06$ & \\
\hline Bi-214 & $4.58 \mathrm{E}-05$ & $3.52 \mathrm{E}-07$ & \\
\hline Bi-215 & $3.37 \mathrm{E}-12$ & $2.59 \mathrm{E}-14$ & \\
\hline Bk-247 & $3.11 \mathrm{E}-04$ & 2.39E-06 & \\
\hline Cd-113 & $8.54 \mathrm{E}-18$ & $6.57 \mathrm{E}-20$ & \\
\hline Cd-113m & $1.13 \mathrm{E}-06$ & 8.71E-09 & \\
\hline Cf-249 & $1.29 \mathrm{E}-03$ & 9.94E-06 & \\
\hline Cf-250 & $3.82 \mathrm{E}-12$ & $2.94 \mathrm{E}-14$ & \\
\hline Cf-251 & 4.04E-03 & $3.11 \mathrm{E}-05$ & \\
\hline Cf- 252 & $6.86 \mathrm{E}-37$ & $5.28 \mathrm{E}-39$ & \\
\hline $\mathrm{Cl}-36$ & 4.07E-03 & $3.13 \mathrm{E}-05$ & \\
\hline $\mathrm{Cm}-242$ & $6.09 \mathrm{E}-03$ & 4.69E-05 & \\
\hline $\mathrm{Cm}-243$ & $2.63 \mathrm{E}-04$ & $2.03 \mathrm{E}-06$ & \\
\hline $\mathrm{Cm}-244$ & $1.55 \mathrm{E}-04$ & $1.19 \mathrm{E}-06$ & \\
\hline $\mathrm{Cm}-245$ & $2.61 \mathrm{E}-03$ & $2.01 \mathrm{E}-05$ & \\
\hline $\mathrm{Cm}-246$ & $6.31 \mathrm{E}-03$ & $4.86 \mathrm{E}-05$ & \\
\hline $\mathrm{Cm}-247$ & $9.22 \mathrm{E}-08$ & $7.09 \mathrm{E}-10$ & \\
\hline $\mathrm{Cm}-248$ & $1.39 \mathrm{E}-06$ & $1.07 \mathrm{E}-08$ & \\
\hline Co-60 & $1.37 \mathrm{E}-17$ & $1.05 \mathrm{E}-19$ & \\
\hline Cs-135 & $3.32 \mathrm{E}-03$ & $2.56 \mathrm{E}-05$ & \\
\hline Cs-137 & $5.92 \mathrm{E}-01$ & $4.56 \mathrm{E}-03$ & Yes \\
\hline Eu-154 & $3.38 \mathrm{E}-10$ & $2.60 \mathrm{E}-12$ & \\
\hline Eu-155 & $2.16 \mathrm{E}-19$ & $1.66 \mathrm{E}-21$ & \\
\hline Fr-221 & $1.21 \mathrm{E}-03$ & $9.31 \mathrm{E}-06$ & \\
\hline Fr-223 & $5.79 \mathrm{E}-08$ & $4.46 \mathrm{E}-10$ & \\
\hline $\mathrm{Hg}-206$ & $7.71 \mathrm{E}-13$ & $5.93 \mathrm{E}-15$ & \\
\hline I-129 & $1.06 \mathrm{E}-03$ & $8.16 \mathrm{E}-06$ & \\
\hline $\mathrm{Nb}-93 \mathrm{~m}$ & $4.51 \mathrm{E}-01$ & $3.47 \mathrm{E}-03$ & Yes \\
\hline $\mathrm{Ni}-59$ & $2.56 \mathrm{E}+00$ & $1.97 \mathrm{E}-02$ & Yes \\
\hline $\mathrm{Ni}-63$ & $1.98 \mathrm{E}+01$ & $1.53 \mathrm{E}-01$ & Yes \\
\hline Np-237 & $2.75 \mathrm{E}-02$ & $2.12 \mathrm{E}-04$ & Yes \\
\hline Np-238 & 3.39E-05 & $2.61 \mathrm{E}-07$ & \\
\hline Np-239 & $4.85 \mathrm{E}-01$ & $3.73 \mathrm{E}-03$ & \\
\hline Np-240 & $3.33 \mathrm{E}-12$ & $2.56 \mathrm{E}-14$ & \\
\hline $\mathrm{Pa}-231$ & $4.60 \mathrm{E}-06$ & $3.54 \mathrm{E}-08$ & \\
\hline $\mathrm{Pa}-233$ & $2.75 \mathrm{E}-02$ & $2.12 \mathrm{E}-04$ & \\
\hline $\mathrm{Pa}-234$ & $2.40 \mathrm{E}-05$ & $1.85 \mathrm{E}-07$ & \\
\hline Pa-234m & $1.60 \mathrm{E}-02$ & $1.23 \mathrm{E}-04$ & \\
\hline Pb-209 & $1.21 \mathrm{E}-03$ & $9.31 \mathrm{E}-06$ & \\
\hline $\mathrm{Pb}-210$ & $4.06 \mathrm{E}-05$ & $3.12 \mathrm{E}-07$ & \\
\hline $\mathrm{Pb}-211$ & $4.20 \mathrm{E}-06$ & 3.23E-08 & \\
\hline $\mathrm{Pb}-212$ & $1.19 \mathrm{E}-03$ & $9.16 \mathrm{E}-06$ & \\
\hline $\mathrm{Pb}-214$ & $4.58 \mathrm{E}-05$ & $3.52 \mathrm{E}-07$ & \\
\hline
\end{tabular}

\begin{tabular}{|c|c|c|c|}
\hline Nuclide & $\begin{array}{l}Y 2315 \\
\mu \mathrm{Ci} / \mathrm{g}\end{array}$ & $\begin{array}{c}\text { Fraction of } \\
\text { Activity }\end{array}$ & Reportable \\
\hline Pd-107 & $1.22 \mathrm{E}-03$ & $9.39 \mathrm{E}-06$ & \\
\hline Pm-147 & $2.95 \mathrm{E}-33$ & $2.27 \mathrm{E}-35$ & \\
\hline Po-210 & $4.05 \mathrm{E}-05$ & $3.12 \mathrm{E}-07$ & \\
\hline Po-211 & $1.15 \mathrm{E}-08$ & $8.81 \mathrm{E}-11$ & \\
\hline Po-212 & 7.62E-04 & $5.87 \mathrm{E}-06$ & \\
\hline Po-213 & $1.18 \mathrm{E}-03$ & $9.11 \mathrm{E}-06$ & \\
\hline Рo-214 & $4.58 \mathrm{E}-05$ & $3.52 \mathrm{E}-07$ & \\
\hline Po-215 & $4.20 \mathrm{E}-06$ & $3.23 \mathrm{E}-08$ & \\
\hline Po-216 & $1.19 \mathrm{E}-03$ & $9.16 \mathrm{E}-06$ & \\
\hline Po-218 & $4.58 \mathrm{E}-05$ & $3.52 \mathrm{E}-07$ & \\
\hline $\mathrm{Pu}-238$ & $1.30 \mathrm{E}+01$ & $9.97 \mathrm{E}-02$ & Yes \\
\hline $\mathrm{Pu}-239$ & $1.07 \mathrm{E}+01$ & $8.24 \mathrm{E}-02$ & Yes \\
\hline $\mathrm{Pu}-240$ & $3.53 \mathrm{E}+00$ & $2.71 \mathrm{E}-02$ & Yes \\
\hline $\mathrm{Pu}-241$ & $2.63 \mathrm{E}-03$ & $2.03 \mathrm{E}-05$ & \\
\hline $\mathrm{Pu}-242$ & 8.98E-03 & $6.91 \mathrm{E}-05$ & \\
\hline $\mathrm{Pu}-243$ & $9.22 \mathrm{E}-08$ & $7.09 \mathrm{E}-10$ & \\
\hline $\mathrm{Pu}-244$ & $3.34 \mathrm{E}-12$ & $2.57 \mathrm{E}-14$ & \\
\hline Ra-223 & $4.20 \mathrm{E}-06$ & $3.23 \mathrm{E}-08$ & \\
\hline Ra-224 & 1.19E-03 & $9.16 \mathrm{E}-06$ & \\
\hline Ra-225 & $1.21 \mathrm{E}-03$ & $9.31 \mathrm{E}-06$ & \\
\hline Ra-226 & $4.58 \mathrm{E}-05$ & $3.52 \mathrm{E}-07$ & \\
\hline Ra-228 & $1.19 \mathrm{E}-03$ & $9.16 \mathrm{E}-06$ & \\
\hline $\mathrm{Rn}-217$ & $1.45 \mathrm{E}-07$ & $1.12 \mathrm{E}-09$ & \\
\hline Rn-218 & $8.70 \mathrm{E}-12$ & $6.69 \mathrm{E}-14$ & \\
\hline Rn-219 & $4.20 \mathrm{E}-06$ & $3.23 \mathrm{E}-08$ & \\
\hline $\mathrm{Rn}-220$ & $1.19 \mathrm{E}-03$ & $9.16 \mathrm{E}-06$ & \\
\hline Rn-222 & $4.58 \mathrm{E}-05$ & $3.52 \mathrm{E}-07$ & \\
\hline Sb-125 & $3.14 \mathrm{E}-34$ & $2.41 \mathrm{E}-36$ & \\
\hline $\mathrm{Sb}-126$ & $9.83 \mathrm{E}-02$ & $7.57 \mathrm{E}-04$ & \\
\hline $\mathrm{Sb}-126 \mathrm{~m}$ & $7.02 \mathrm{E}-01$ & $5.41 \mathrm{E}-03$ & \\
\hline Sb-126m2 & $4.70 \mathrm{E}-01$ & $3.62 \mathrm{E}-03$ & \\
\hline Se-79 & $1.54 \mathrm{E}-02$ & $1.19 \mathrm{E}-04$ & Yes \\
\hline Sm-147 & $4.28 \mathrm{E}-09$ & $3.30 \mathrm{E}-11$ & \\
\hline Sm-151 & $2.40 \mathrm{E}+01$ & $1.84 \mathrm{E}-01$ & Yes \\
\hline Sn-121 & $8.44 \mathrm{E}-03$ & $6.49 \mathrm{E}-05$ & \\
\hline $\mathrm{Sn}-121 \mathrm{~m}$ & $1.09 \mathrm{E}-02$ & 8.37E-05 & \\
\hline Sn-126 & $7.02 \mathrm{E}-01$ & $5.41 \mathrm{E}-03$ & Yes \\
\hline Sr-90 & $8.62 \mathrm{E}+00$ & $6.64 \mathrm{E}-02$ & Yes \\
\hline Tc-99 & $9.66 \mathrm{E}-02$ & 7.43E-04 & Yes \\
\hline $\mathrm{Te}-125 \mathrm{~m}$ & $7.44 \mathrm{E}-35$ & $5.72 \mathrm{E}-37$ & \\
\hline Th-227 & $4.14 \mathrm{E}-06$ & $3.18 \mathrm{E}-08$ & \\
\hline Th-228 & $1.19 \mathrm{E}-03$ & $9.16 \mathrm{E}-06$ & \\
\hline Th-229 & $1.21 \mathrm{E}-03$ & $9.32 \mathrm{E}-06$ & \\
\hline Th-230 & $4.42 \mathrm{E}-04$ & $3.40 \mathrm{E}-06$ & \\
\hline Th-231 & $6.15 \mathrm{E}-04$ & 4.73E-06 & \\
\hline Th-232 & $1.19 \mathrm{E}-03$ & $9.16 \mathrm{E}-06$ & \\
\hline Th-234 & $1.60 \mathrm{E}-02$ & $1.23 \mathrm{E}-04$ & \\
\hline Tl-206 & $5.43 \mathrm{E}-11$ & $4.18 \mathrm{E}-13$ & \\
\hline Tl-207 & $4.18 \mathrm{E}-06$ & $3.22 \mathrm{E}-08$ & \\
\hline Tl-208 & $4.28 \mathrm{E}-04$ & $3.29 \mathrm{E}-06$ & \\
\hline Tl-209 & $2.61 \mathrm{E}-05$ & $2.01 \mathrm{E}-07$ & \\
\hline $\mathrm{Tl}-210$ & $9.62 \mathrm{E}-09$ & $7.40 \mathrm{E}-11$ & \\
\hline U-233 & $4.22 \mathrm{E}-02$ & $3.25 \mathrm{E}-04$ & Yes \\
\hline U-234 & $8.66 \mathrm{E}-02$ & $6.67 \mathrm{E}-04$ & Yes \\
\hline U-235 & $6.15 \mathrm{E}-04$ & $4.73 \mathrm{E}-06$ & \\
\hline $\mathrm{U}-235 \mathrm{~m}$ & $1.07 \mathrm{E}+01$ & 8.23E-02 & \\
\hline U-236 & $9.35 \mathrm{E}-04$ & 7.19E-06 & \\
\hline U-237 & $6.48 \mathrm{E}-08$ & $4.98 \mathrm{E}-10$ & \\
\hline U-238 & $1.60 \mathrm{E}-02$ & $1.23 \mathrm{E}-04$ & Yes \\
\hline $\mathrm{U}-240$ & $3.33 \mathrm{E}-12$ & $2.56 \mathrm{E}-14$ & \\
\hline Y-90 & $8.63 \mathrm{E}+00$ & $6.64 \mathrm{E}-02$ & \\
\hline Zr-93 & $4.63 \mathrm{E}-01$ & $3.56 \mathrm{E}-03$ & Yes \\
\hline TOTAL & $1.30 \mathrm{E}+02$ & $1.00 \mathrm{E}+00$ & \\
\hline
\end{tabular}


SRNL-STI-2012-00294

Revision 0

\begin{tabular}{|c|c|c|c|}
\hline Nuclide & $\begin{array}{l}\text { Y } 2415 \\
\mu \mathrm{Ci} / \mathrm{g}\end{array}$ & $\begin{array}{c}\text { Fraction of } \\
\text { Activity }\end{array}$ & Reportable \\
\hline Ac-225 & $1.60 \mathrm{E}-03$ & $2.00 \mathrm{E}-05$ & \\
\hline Ac-227 & $5.49 \mathrm{E}-06$ & $6.87 \mathrm{E}-08$ & \\
\hline Ac-228 & $1.19 \mathrm{E}-03$ & 1.49E-05 & \\
\hline Am-241 & $1.96 \mathrm{E}+01$ & $2.45 \mathrm{E}-01$ & Yes \\
\hline Am-242 & $4.46 \mathrm{E}-03$ & 5.59E-05 & \\
\hline Am-242m & 4.48E-03 & $5.61 \mathrm{E}-05$ & \\
\hline Am-243 & $4.80 \mathrm{E}-01$ & $6.01 \mathrm{E}-03$ & Yes \\
\hline At-215 & $2.20 \mathrm{E}-11$ & $2.75 \mathrm{E}-13$ & \\
\hline At-217 & $1.60 \mathrm{E}-03$ & $2.00 \mathrm{E}-05$ & \\
\hline At-218 & $1.22 \mathrm{E}-08$ & $1.53 \mathrm{E}-10$ & \\
\hline At-219 & $4.55 \mathrm{E}-12$ & $5.69 \mathrm{E}-14$ & \\
\hline Ba-133 & $5.78 \mathrm{E}-13$ & $7.24 \mathrm{E}-15$ & \\
\hline $\mathrm{Ba}-137 \mathrm{~m}$ & 5.57E-02 & $6.97 \mathrm{E}-04$ & \\
\hline Bi-209 & $1.20 \mathrm{E}-20$ & $1.50 \mathrm{E}-22$ & \\
\hline Bi-210 & $5.82 \mathrm{E}-05$ & 7.29E-07 & \\
\hline Bi-211 & $5.49 \mathrm{E}-06$ & $6.87 \mathrm{E}-08$ & \\
\hline Bi-212 & $1.19 \mathrm{E}-03$ & $1.49 \mathrm{E}-05$ & \\
\hline Bi-213 & $1.60 \mathrm{E}-03$ & $2.00 \mathrm{E}-05$ & \\
\hline Bi-214 & $6.43 \mathrm{E}-05$ & $8.05 \mathrm{E}-07$ & \\
\hline Bi-215 & $4.41 \mathrm{E}-12$ & $5.52 \mathrm{E}-14$ & \\
\hline Bk-247 & $2.96 \mathrm{E}-04$ & $3.70 \mathrm{E}-06$ & \\
\hline Cd-113 & $8.54 \mathrm{E}-18$ & $1.07 \mathrm{E}-19$ & \\
\hline $\mathrm{Cd}-113 \mathrm{~m}$ & 8.29E-09 & $1.04 \mathrm{E}-10$ & \\
\hline Cf-249 & $1.06 \mathrm{E}-03$ & $1.33 \mathrm{E}-05$ & \\
\hline Cf-250 & $1.91 \mathrm{E}-14$ & $2.39 \mathrm{E}-16$ & \\
\hline Cf-251 & $3.74 \mathrm{E}-03$ & $4.68 \mathrm{E}-05$ & \\
\hline Cf-252 & $2.86 \mathrm{E}-48$ & $3.57 \mathrm{E}-50$ & \\
\hline $\mathrm{Cl}-36$ & 4.07E-03 & 5.09E-05 & \\
\hline $\mathrm{Cm}-242$ & $3.72 \mathrm{E}-03$ & $4.66 \mathrm{E}-05$ & \\
\hline $\mathrm{Cm}-243$ & $2.61 \mathrm{E}-05$ & $3.27 \mathrm{E}-07$ & \\
\hline $\mathrm{Cm}-244$ & $3.30 \mathrm{E}-06$ & $4.13 \mathrm{E}-08$ & \\
\hline $\mathrm{Cm}-245$ & $2.60 \mathrm{E}-03$ & $3.25 \mathrm{E}-05$ & \\
\hline $\mathrm{Cm}-246$ & $6.22 \mathrm{E}-03$ & 7.79E-05 & \\
\hline $\mathrm{Cm}-247$ & $1.09 \mathrm{E}-07$ & $1.36 \mathrm{E}-09$ & \\
\hline $\mathrm{Cm}-248$ & $1.39 \mathrm{E}-06$ & $1.74 \mathrm{E}-08$ & \\
\hline Co-60 & $2.66 \mathrm{E}-23$ & $3.34 \mathrm{E}-25$ & \\
\hline Cs-135 & $3.32 \mathrm{E}-03$ & $4.16 \mathrm{E}-05$ & \\
\hline Cs-137 & $5.90 \mathrm{E}-02$ & 7.38E-04 & Yes \\
\hline Eu-154 & $1.06 \mathrm{E}-13$ & $1.33 \mathrm{E}-15$ & \\
\hline Eu-155 & $1.00 \mathrm{E}-25$ & $1.25 \mathrm{E}-27$ & \\
\hline Fr-221 & $1.60 \mathrm{E}-03$ & $2.00 \mathrm{E}-05$ & \\
\hline Fr-223 & 7.57E-08 & $9.48 \mathrm{E}-10$ & \\
\hline $\mathrm{Hg}-206$ & $1.11 \mathrm{E}-12$ & $1.38 \mathrm{E}-14$ & \\
\hline I-129 & $1.06 \mathrm{E}-03$ & $1.33 \mathrm{E}-05$ & \\
\hline $\mathrm{Nb}-93 \mathrm{~m}$ & $4.51 \mathrm{E}-01$ & $5.65 \mathrm{E}-03$ & Yes \\
\hline $\mathrm{Ni}-59$ & $2.56 \mathrm{E}+00$ & $3.21 \mathrm{E}-02$ & Yes \\
\hline $\mathrm{Ni}-63$ & $9.96 \mathrm{E}+00$ & $1.25 \mathrm{E}-01$ & Yes \\
\hline Np-237 & $2.82 \mathrm{E}-02$ & $3.53 \mathrm{E}-04$ & Yes \\
\hline Np-238 & $2.08 \mathrm{E}-05$ & $2.60 \mathrm{E}-07$ & \\
\hline Np-239 & $4.80 \mathrm{E}-01$ & $6.01 \mathrm{E}-03$ & \\
\hline Np-240 & $4.43 \mathrm{E}-12$ & $5.55 \mathrm{E}-14$ & \\
\hline $\mathrm{Pa}-231$ & $5.89 \mathrm{E}-06$ & 7.38E-08 & \\
\hline $\mathrm{Pa}-233$ & $2.82 \mathrm{E}-02$ & $3.53 \mathrm{E}-04$ & \\
\hline $\mathrm{Pa}-234$ & $2.40 \mathrm{E}-05$ & $3.00 \mathrm{E}-07$ & \\
\hline Pa-234m & $1.60 \mathrm{E}-02$ & $2.00 \mathrm{E}-04$ & \\
\hline Pb-209 & $1.60 \mathrm{E}-03$ & $2.00 \mathrm{E}-05$ & \\
\hline $\mathrm{Pb}-210$ & $5.82 \mathrm{E}-05$ & 7.29E-07 & \\
\hline $\mathrm{Pb}-211$ & $5.49 \mathrm{E}-06$ & $6.87 \mathrm{E}-08$ & \\
\hline $\mathrm{Pb}-212$ & $1.19 \mathrm{E}-03$ & $1.49 \mathrm{E}-05$ & \\
\hline $\mathrm{Pb}-214$ & $6.43 \mathrm{E}-05$ & $8.05 \mathrm{E}-07$ & \\
\hline
\end{tabular}

\begin{tabular}{|c|c|c|c|}
\hline Nuclide & $\begin{array}{l}Y 2415 \\
\mu \mathrm{Ci} / \mathrm{g}\end{array}$ & $\begin{array}{c}\text { Fraction of } \\
\text { Activity }\end{array}$ & Reportable \\
\hline Pd-107 & $1.22 \mathrm{E}-03$ & $1.53 \mathrm{E}-05$ & \\
\hline Pm-147 & $9.91 \mathrm{E}-45$ & $1.24 \mathrm{E}-46$ & \\
\hline Po-210 & $5.81 \mathrm{E}-05$ & $7.28 \mathrm{E}-07$ & \\
\hline Po-211 & $1.50 \mathrm{E}-08$ & $1.88 \mathrm{E}-10$ & \\
\hline Po-212 & 7.62E-04 & $9.54 \mathrm{E}-06$ & \\
\hline Po-213 & $1.56 \mathrm{E}-03$ & $1.95 \mathrm{E}-05$ & \\
\hline Рo-214 & $6.43 \mathrm{E}-05$ & $8.05 \mathrm{E}-07$ & \\
\hline Po-215 & $5.49 \mathrm{E}-06$ & $6.87 \mathrm{E}-08$ & \\
\hline Po-216 & $1.19 \mathrm{E}-03$ & $1.49 \mathrm{E}-05$ & \\
\hline Po-218 & $6.43 \mathrm{E}-05$ & $8.05 \mathrm{E}-07$ & \\
\hline $\mathrm{Pu}-238$ & $5.88 \mathrm{E}+00$ & 7.36E-02 & Yes \\
\hline $\mathrm{Pu}-239$ & $1.07 \mathrm{E}+01$ & $1.34 \mathrm{E}-01$ & Yes \\
\hline $\mathrm{Pu}-240$ & $3.49 \mathrm{E}+00$ & $4.37 \mathrm{E}-02$ & Yes \\
\hline $\mathrm{Pu}-241$ & $2.60 \mathrm{E}-03$ & $3.26 \mathrm{E}-05$ & \\
\hline $\mathrm{Pu}-242$ & 8.98E-03 & $1.12 \mathrm{E}-04$ & Yes \\
\hline $\mathrm{Pu}-243$ & $1.09 \mathrm{E}-07$ & $1.36 \mathrm{E}-09$ & \\
\hline $\mathrm{Pu}-244$ & $4.44 \mathrm{E}-12$ & $5.56 \mathrm{E}-14$ & \\
\hline Ra-223 & $5.49 \mathrm{E}-06$ & $6.87 \mathrm{E}-08$ & \\
\hline Ra-224 & 1.19E-03 & 1.49E-05 & \\
\hline Ra-225 & $1.60 \mathrm{E}-03$ & $2.00 \mathrm{E}-05$ & \\
\hline Ra-226 & $6.43 \mathrm{E}-05$ & $8.05 \mathrm{E}-07$ & \\
\hline Ra-228 & $1.19 \mathrm{E}-03$ & $1.49 \mathrm{E}-05$ & \\
\hline $\mathrm{Rn}-217$ & $1.91 \mathrm{E}-07$ & $2.40 \mathrm{E}-09$ & \\
\hline Rn-218 & $1.22 \mathrm{E}-11$ & $1.53 \mathrm{E}-13$ & \\
\hline Rn-219 & $5.49 \mathrm{E}-06$ & $6.87 \mathrm{E}-08$ & \\
\hline Rn-220 & $1.19 \mathrm{E}-03$ & $1.49 \mathrm{E}-05$ & \\
\hline Rn-222 & $6.43 \mathrm{E}-05$ & $8.05 \mathrm{E}-07$ & \\
\hline Sb-125 & $3.83 \mathrm{E}-45$ & $4.80 \mathrm{E}-47$ & \\
\hline $\mathrm{Sb}-126$ & $9.83 \mathrm{E}-02$ & $1.23 \mathrm{E}-03$ & \\
\hline $\mathrm{Sb}-126 \mathrm{~m}$ & $7.02 \mathrm{E}-01$ & 8.79E-03 & \\
\hline Sb-126m2 & $4.70 \mathrm{E}-01$ & $5.88 \mathrm{E}-03$ & \\
\hline Se-79 & $1.54 \mathrm{E}-02$ & $1.93 \mathrm{E}-04$ & Yes \\
\hline Sm-147 & $4.28 \mathrm{E}-09$ & $5.36 \mathrm{E}-11$ & \\
\hline Sm-151 & $1.11 \mathrm{E}+01$ & 1.39E-01 & Yes \\
\hline Sn-121 & $2.39 \mathrm{E}-03$ & 2.99E-05 & \\
\hline $\mathrm{Sn}-121 \mathrm{~m}$ & $3.08 \mathrm{E}-03$ & $3.86 \mathrm{E}-05$ & \\
\hline Sn-126 & $7.02 \mathrm{E}-01$ & 8.79E-03 & Yes \\
\hline Sr-90 & 7.76E-01 & $9.72 \mathrm{E}-03$ & Yes \\
\hline Tc-99 & $9.66 \mathrm{E}-02$ & $1.21 \mathrm{E}-03$ & Yes \\
\hline $\mathrm{Te}-125 \mathrm{~m}$ & $9.10 \mathrm{E}-46$ & $1.14 \mathrm{E}-47$ & \\
\hline Th-227 & $5.41 \mathrm{E}-06$ & $6.78 \mathrm{E}-08$ & \\
\hline Th-228 & $1.19 \mathrm{E}-03$ & $1.49 \mathrm{E}-05$ & \\
\hline Th-229 & $1.60 \mathrm{E}-03$ & $2.00 \mathrm{E}-05$ & \\
\hline Th-230 & $5.22 \mathrm{E}-04$ & $6.54 \mathrm{E}-06$ & \\
\hline Th-231 & $6.16 \mathrm{E}-04$ & 7.72E-06 & \\
\hline Th-232 & $1.19 \mathrm{E}-03$ & $1.49 \mathrm{E}-05$ & \\
\hline Th-234 & $1.60 \mathrm{E}-02$ & $2.00 \mathrm{E}-04$ & \\
\hline Tl-206 & $7.79 \mathrm{E}-11$ & $9.76 \mathrm{E}-13$ & \\
\hline Tl-207 & $5.47 \mathrm{E}-06$ & $6.85 \mathrm{E}-08$ & \\
\hline Tl-208 & $4.28 \mathrm{E}-04$ & $5.35 \mathrm{E}-06$ & \\
\hline Tl-209 & $3.45 \mathrm{E}-05$ & $4.31 \mathrm{E}-07$ & \\
\hline $\mathrm{Tl}-210$ & $1.35 \mathrm{E}-08$ & $1.69 \mathrm{E}-10$ & \\
\hline U-233 & $4.22 \mathrm{E}-02$ & $5.28 \mathrm{E}-04$ & Yes \\
\hline U-234 & 8.91E-02 & $1.12 \mathrm{E}-03$ & Yes \\
\hline U-235 & $6.16 \mathrm{E}-04$ & 7.72E-06 & \\
\hline $\mathrm{U}-235 \mathrm{~m}$ & $1.07 \mathrm{E}+01$ & $1.34 \mathrm{E}-01$ & \\
\hline U-236 & $9.45 \mathrm{E}-04$ & $1.18 \mathrm{E}-05$ & \\
\hline U-237 & $6.40 \mathrm{E}-08$ & $8.01 \mathrm{E}-10$ & \\
\hline U-238 & $1.60 \mathrm{E}-02$ & $2.00 \mathrm{E}-04$ & Yes \\
\hline $\mathrm{U}-240$ & $4.43 \mathrm{E}-12$ & $5.55 \mathrm{E}-14$ & \\
\hline Y-90 & 7.77E-01 & $9.72 \mathrm{E}-03$ & \\
\hline Zr-93 & $4.63 \mathrm{E}-01$ & $5.80 \mathrm{E}-03$ & Yes \\
\hline TOTAL & $7.99 \mathrm{E}+01$ & $1.00 \mathrm{E}+00$ & \\
\hline
\end{tabular}


APPENDIX F. ACTIVITIES OF DRIED SLUDGE IN YEAR $2515(\mu \mathrm{Ci} / \mathrm{g})$ 
SRNL-STI-2012-00294

Revision 0

\begin{tabular}{|c|c|c|c|}
\hline Nuclide & $\begin{array}{l}\text { Y } 2515 \\
\mu \mathrm{Ci} / \mathrm{g}\end{array}$ & $\begin{array}{c}\text { Fraction of } \\
\text { Activity }\end{array}$ & Reportable \\
\hline Ac-225 & $1.98 \mathrm{E}-03$ & $3.23 \mathrm{E}-05$ & \\
\hline Ac-227 & $6.78 \mathrm{E}-06$ & $1.11 \mathrm{E}-07$ & \\
\hline Ac-228 & $1.19 \mathrm{E}-03$ & $1.94 \mathrm{E}-05$ & \\
\hline Am-241 & $1.67 \mathrm{E}+01$ & $2.73 \mathrm{E}-01$ & Yes \\
\hline Am-242 & $2.73 \mathrm{E}-03$ & $4.46 \mathrm{E}-05$ & \\
\hline$A m-242 m$ & $2.74 \mathrm{E}-03$ & $4.48 \mathrm{E}-05$ & \\
\hline Am-243 & 4.76E-01 & 7.77E-03 & Yes \\
\hline At-215 & $2.71 \mathrm{E}-11$ & $4.43 \mathrm{E}-13$ & \\
\hline At-217 & $1.98 \mathrm{E}-03$ & $3.23 \mathrm{E}-05$ & \\
\hline At-218 & $1.62 \mathrm{E}-08$ & $2.65 \mathrm{E}-10$ & \\
\hline At-219 & $5.61 \mathrm{E}-12$ & $9.17 \mathrm{E}-14$ & \\
\hline Ba-133 & $8.05 \mathrm{E}-16$ & $1.32 \mathrm{E}-17$ & \\
\hline Ba-137m & $5.54 \mathrm{E}-03$ & $9.05 \mathrm{E}-05$ & \\
\hline Bi-209 & $1.85 \mathrm{E}-20$ & $3.02 \mathrm{E}-22$ & \\
\hline Bi-210 & 7.85E-05 & $1.28 \mathrm{E}-06$ & \\
\hline Bi-211 & $6.78 \mathrm{E}-06$ & $1.11 \mathrm{E}-07$ & \\
\hline Bi-212 & $1.19 \mathrm{E}-03$ & $1.94 \mathrm{E}-05$ & \\
\hline Bi-213 & $1.98 \mathrm{E}-03$ & $3.23 \mathrm{E}-05$ & \\
\hline Bi-214 & $8.54 \mathrm{E}-05$ & $1.40 \mathrm{E}-06$ & \\
\hline Bi-215 & $5.45 \mathrm{E}-12$ & 8.89E-14 & \\
\hline Bk-247 & $2.81 \mathrm{E}-04$ & $4.59 \mathrm{E}-06$ & \\
\hline Cd-113 & 8.54E-18 & $1.39 \mathrm{E}-19$ & \\
\hline Cd-113m & $6.08 \mathrm{E}-11$ & $9.93 \mathrm{E}-13$ & \\
\hline Cf-249 & $8.70 \mathrm{E}-04$ & $1.42 \mathrm{E}-05$ & \\
\hline Cf-250 & $9.53 \mathrm{E}-17$ & $1.56 \mathrm{E}-18$ & \\
\hline Cf-251 & $3.46 \mathrm{E}-03$ & $5.65 \mathrm{E}-05$ & \\
\hline Cf- 252 & $1.19 \mathrm{E}-59$ & $1.94 \mathrm{E}-61$ & \\
\hline $\mathrm{Cl}-36$ & $4.07 \mathrm{E}-03$ & $6.64 \mathrm{E}-05$ & \\
\hline $\mathrm{Cm}-242$ & $2.28 \mathrm{E}-03$ & $3.72 \mathrm{E}-05$ & \\
\hline $\mathrm{Cm}-243$ & $2.59 \mathrm{E}-06$ & 4.24E-08 & \\
\hline $\mathrm{Cm}-244$ & $7.01 \mathrm{E}-08$ & $1.15 \mathrm{E}-09$ & \\
\hline $\mathrm{Cm}-245$ & $2.58 \mathrm{E}-03$ & 4.22E-05 & \\
\hline $\mathrm{Cm}-246$ & $6.13 \mathrm{E}-03$ & $1.00 \mathrm{E}-04$ & Yes \\
\hline $\mathrm{Cm}-247$ & $1.25 \mathrm{E}-07$ & 2.04E-09 & \\
\hline $\mathrm{Cm}-248$ & $1.39 \mathrm{E}-06$ & $2.26 \mathrm{E}-08$ & \\
\hline Co-60 & $5.18 \mathrm{E}-29$ & $8.47 \mathrm{E}-31$ & \\
\hline Cs-135 & 3.32E-03 & $5.42 \mathrm{E}-05$ & \\
\hline Cs-137 & 5.87E-03 & $9.59 \mathrm{E}-05$ & \\
\hline Eu-154 & $3.33 \mathrm{E}-17$ & $5.43 \mathrm{E}-19$ & \\
\hline Eu-155 & 4.64E-32 & $7.58 \mathrm{E}-34$ & \\
\hline Fr-221 & $1.98 \mathrm{E}-03$ & $3.23 \mathrm{E}-05$ & \\
\hline Fr-223 & $9.36 \mathrm{E}-08$ & $1.53 \mathrm{E}-09$ & \\
\hline $\mathrm{Hg}-206$ & $1.49 \mathrm{E}-12$ & $2.44 \mathrm{E}-14$ & \\
\hline I-129 & $1.06 \mathrm{E}-03$ & $1.73 \mathrm{E}-05$ & \\
\hline $\mathrm{Nb}-93 \mathrm{~m}$ & 4.51E-01 & 7.37E-03 & Yes \\
\hline $\mathrm{Ni}-59$ & $2.56 \mathrm{E}+00$ & $4.18 \mathrm{E}-02$ & Yes \\
\hline $\mathrm{Ni}-63$ & $5.00 \mathrm{E}+00$ & $8.17 \mathrm{E}-02$ & Yes \\
\hline Np-237 & $2.88 \mathrm{E}-02$ & $4.70 \mathrm{E}-04$ & Yes \\
\hline Np-238 & $1.27 \mathrm{E}-05$ & 2.07E-07 & \\
\hline Np-239 & $4.76 \mathrm{E}-01$ & 7.77E-03 & \\
\hline Np-240 & $5.53 \mathrm{E}-12$ & $9.04 \mathrm{E}-14$ & \\
\hline $\mathrm{Pa}-231$ & 7.19E-06 & $1.17 \mathrm{E}-07$ & \\
\hline $\mathrm{Pa}-233$ & $2.88 \mathrm{E}-02$ & $4.70 \mathrm{E}-04$ & \\
\hline Pa-234 & $2.40 \mathrm{E}-05$ & 3.92E-07 & \\
\hline $\mathrm{Pa}-234 \mathrm{~m}$ & $1.60 \mathrm{E}-02$ & $2.61 \mathrm{E}-04$ & \\
\hline $\mathrm{Pb}-209$ & $1.98 \mathrm{E}-03$ & $3.23 \mathrm{E}-05$ & \\
\hline $\mathrm{Pb}-210$ & $7.85 \mathrm{E}-05$ & $1.28 \mathrm{E}-06$ & \\
\hline $\mathrm{Pb}-211$ & $6.78 \mathrm{E}-06$ & $1.11 \mathrm{E}-07$ & \\
\hline $\mathrm{Pb}-212$ & $1.19 \mathrm{E}-03$ & $1.94 \mathrm{E}-05$ & \\
\hline $\mathrm{Pb}-214$ & $8.54 \mathrm{E}-05$ & $1.40 \mathrm{E}-06$ & \\
\hline
\end{tabular}

\begin{tabular}{|c|c|c|c|}
\hline Nuclide & $\begin{array}{c}\text { Y } 2515 \\
\mu \mathrm{Ci} / \mathrm{g}\end{array}$ & $\begin{array}{c}\text { Fraction of } \\
\text { Activity }\end{array}$ & Reportable \\
\hline Pd-107 & $1.22 \mathrm{E}-03$ & $1.99 \mathrm{E}-05$ & \\
\hline Pm-147 & $3.32 \mathrm{E}-56$ & $5.43 \mathrm{E}-58$ & \\
\hline Po-210 & $7.84 \mathrm{E}-05$ & $1.28 \mathrm{E}-06$ & \\
\hline Po-211 & $1.85 \mathrm{E}-08$ & $3.02 \mathrm{E}-10$ & \\
\hline Po-212 & $7.62 \mathrm{E}-04$ & $1.25 \mathrm{E}-05$ & \\
\hline Po-213 & $1.93 \mathrm{E}-03$ & $3.16 \mathrm{E}-05$ & \\
\hline Po-214 & $8.54 \mathrm{E}-05$ & $1.40 \mathrm{E}-06$ & \\
\hline Po-215 & $6.78 \mathrm{E}-06$ & $1.11 \mathrm{E}-07$ & \\
\hline Po-216 & $1.19 \mathrm{E}-03$ & $1.94 \mathrm{E}-05$ & \\
\hline Po-218 & $8.54 \mathrm{E}-05$ & $1.40 \mathrm{E}-06$ & \\
\hline $\mathrm{Pu}-238$ & $2.67 \mathrm{E}+00$ & $4.36 \mathrm{E}-02$ & Yes \\
\hline Pu-239 & $1.07 \mathrm{E}+01$ & $1.74 \mathrm{E}-01$ & Yes \\
\hline $\mathrm{Pu}-240$ & $3.45 \mathrm{E}+00$ & $5.64 \mathrm{E}-02$ & Yes \\
\hline $\mathrm{Pu}-241$ & $2.59 \mathrm{E}-03$ & $4.23 \mathrm{E}-05$ & \\
\hline $\mathrm{Pu}-242$ & $8.98 \mathrm{E}-03$ & $1.47 \mathrm{E}-04$ & Yes \\
\hline $\mathrm{Pu}-243$ & $1.25 \mathrm{E}-07$ & $2.04 \mathrm{E}-09$ & \\
\hline $\mathrm{Pu}-244$ & $5.54 \mathrm{E}-12$ & $9.05 \mathrm{E}-14$ & \\
\hline $\mathrm{Ra}-223$ & $6.78 \mathrm{E}-06$ & $1.11 \mathrm{E}-07$ & \\
\hline $\mathrm{Ra}-224$ & $1.19 \mathrm{E}-03$ & $1.94 \mathrm{E}-05$ & \\
\hline Ra-225 & $1.98 \mathrm{E}-03$ & $3.23 \mathrm{E}-05$ & \\
\hline $\mathrm{Ra}-226$ & $8.55 \mathrm{E}-05$ & $1.40 \mathrm{E}-06$ & \\
\hline $\mathrm{Ra}-228$ & $1.19 \mathrm{E}-03$ & $1.94 \mathrm{E}-05$ & \\
\hline $\mathrm{Rn}-217$ & $2.37 \mathrm{E}-07$ & $3.87 \mathrm{E}-09$ & \\
\hline Rn-218 & $1.62 \mathrm{E}-11$ & $2.65 \mathrm{E}-13$ & \\
\hline $\mathrm{Rn}-219$ & $6.78 \mathrm{E}-06$ & $1.11 \mathrm{E}-07$ & \\
\hline $\mathrm{Rn}-220$ & $1.19 \mathrm{E}-03$ & $1.94 \mathrm{E}-05$ & \\
\hline $\mathrm{Rn}-222$ & $8.54 \mathrm{E}-05$ & $1.40 \mathrm{E}-06$ & \\
\hline Sb-125 & $4.69 \mathrm{E}-56$ & $7.66 \mathrm{E}-58$ & \\
\hline Sb-126 & $9.83 \mathrm{E}-02$ & $1.61 \mathrm{E}-03$ & \\
\hline $\mathrm{Sb}-126 \mathrm{~m}$ & $7.02 \mathrm{E}-01$ & $1.15 \mathrm{E}-02$ & \\
\hline Sb-126m2 & $4.70 \mathrm{E}-01$ & 7.67E-03 & \\
\hline Se-79 & $1.54 \mathrm{E}-02$ & $2.52 \mathrm{E}-04$ & Yes \\
\hline Sm-147 & $4.28 \mathrm{E}-09$ & $6.99 \mathrm{E}-11$ & \\
\hline $\mathrm{Sm}-151$ & $5.13 \mathrm{E}+00$ & $8.38 \mathrm{E}-02$ & Yes \\
\hline Sn-121 & $6.78 \mathrm{E}-04$ & $1.11 \mathrm{E}-05$ & \\
\hline $\mathrm{Sn}-121 \mathrm{~m}$ & $8.74 \mathrm{E}-04$ & $1.43 \mathrm{E}-05$ & \\
\hline Sn-126 & $7.02 \mathrm{E}-01$ & $1.15 \mathrm{E}-02$ & Yes \\
\hline $\mathrm{Sr}-90$ & $6.99 \mathrm{E}-02$ & $1.14 \mathrm{E}-03$ & Yes \\
\hline Tc-99 & $9.65 \mathrm{E}-02$ & $1.58 \mathrm{E}-03$ & Yes \\
\hline $\mathrm{Te}-125 \mathrm{~m}$ & $1.11 \mathrm{E}-56$ & $1.82 \mathrm{E}-58$ & \\
\hline Th-227 & $6.69 \mathrm{E}-06$ & $1.09 \mathrm{E}-07$ & \\
\hline Th-228 & $1.19 \mathrm{E}-03$ & $1.94 \mathrm{E}-05$ & \\
\hline Th-229 & $1.98 \mathrm{E}-03$ & $3.23 \mathrm{E}-05$ & \\
\hline Th-230 & $6.04 \mathrm{E}-04$ & $9.87 \mathrm{E}-06$ & \\
\hline Th-231 & $6.17 \mathrm{E}-04$ & $1.01 \mathrm{E}-05$ & \\
\hline Th-232 & $1.19 \mathrm{E}-03$ & $1.94 \mathrm{E}-05$ & \\
\hline Th-234 & $1.60 \mathrm{E}-02$ & 2.61E-04 & \\
\hline Tl-206 & $1.05 \mathrm{E}-10$ & $1.72 \mathrm{E}-12$ & \\
\hline Tl-207 & $6.76 \mathrm{E}-06$ & $1.10 \mathrm{E}-07$ & \\
\hline Tl-208 & $4.28 \mathrm{E}-04$ & $6.99 \mathrm{E}-06$ & \\
\hline Tl-209 & $4.27 \mathrm{E}-05$ & $6.97 \mathrm{E}-07$ & \\
\hline Tl-210 & $1.79 \mathrm{E}-08$ & $2.93 \mathrm{E}-10$ & \\
\hline U-233 & $4.22 \mathrm{E}-02$ & $6.89 \mathrm{E}-04$ & Yes \\
\hline U-234 & $9.03 \mathrm{E}-02$ & $1.47 \mathrm{E}-03$ & Yes \\
\hline U-235 & $6.17 \mathrm{E}-04$ & $1.01 \mathrm{E}-05$ & \\
\hline $\mathrm{U}-235 \mathrm{~m}$ & $1.07 \mathrm{E}+01$ & $1.74 \mathrm{E}-01$ & \\
\hline U-236 & $9.55 \mathrm{E}-04$ & $1.56 \mathrm{E}-05$ & \\
\hline U-237 & $6.36 \mathrm{E}-08$ & 1.04E-09 & \\
\hline U-238 & $1.60 \mathrm{E}-02$ & $2.61 \mathrm{E}-04$ & Yes \\
\hline U-240 & $5.53 \mathrm{E}-12$ & $9.04 \mathrm{E}-14$ & \\
\hline Y-90 & $6.99 \mathrm{E}-02$ & $1.14 \mathrm{E}-03$ & \\
\hline Zr-93 & $4.63 \mathrm{E}-01$ & $7.56 \mathrm{E}-03$ & Yes \\
\hline TOTAL & $6.12 E+01$ & $1.00 \mathrm{E}+00$ & \\
\hline
\end{tabular}




\section{APPENDIX G. ACTIVITIES OF DRIED SLUDGE IN YEAR $2615(\mu \mathrm{Ci} / \mathrm{g})$}


SRNL-STI-2012-00294

Revision 0

\begin{tabular}{|c|c|c|c|}
\hline Nuclide & $\begin{array}{l}\text { Y } 2615 \\
\mu \mathrm{Ci} / \mathrm{g}\end{array}$ & $\begin{array}{c}\text { Fraction of } \\
\text { Activity }\end{array}$ & Reportable \\
\hline Ac-225 & $2.35 \mathrm{E}-03$ & $4.54 \mathrm{E}-05$ & \\
\hline Ac-227 & $8.07 \mathrm{E}-06$ & $1.56 \mathrm{E}-07$ & \\
\hline Ac-228 & 1.19E-03 & $2.30 \mathrm{E}-05$ & \\
\hline Am-241 & $1.42 \mathrm{E}+01$ & $2.75 \mathrm{E}-01$ & Yes \\
\hline Am-242 & $1.67 \mathrm{E}-03$ & $3.22 \mathrm{E}-05$ & \\
\hline Am-242m & $1.68 \mathrm{E}-03$ & $3.24 \mathrm{E}-05$ & \\
\hline Am-243 & $4.72 \mathrm{E}-01$ & $9.10 \mathrm{E}-03$ & Yes \\
\hline At-215 & $3.23 \mathrm{E}-11$ & $6.23 \mathrm{E}-13$ & \\
\hline At-217 & $2.35 \mathrm{E}-03$ & 4.54E-05 & \\
\hline At-218 & $2.08 \mathrm{E}-08$ & $4.01 \mathrm{E}-10$ & \\
\hline At-219 & $6.68 \mathrm{E}-12$ & $1.29 \mathrm{E}-13$ & \\
\hline Ba-133 & $1.12 \mathrm{E}-18$ & $2.17 \mathrm{E}-20$ & \\
\hline $\mathrm{Ba}-137 \mathrm{~m}$ & $5.51 \mathrm{E}-04$ & $1.06 \mathrm{E}-05$ & \\
\hline Bi-209 & $2.64 \mathrm{E}-20$ & $5.09 \mathrm{E}-22$ & \\
\hline Bi-210 & $1.02 \mathrm{E}-04$ & $1.96 \mathrm{E}-06$ & \\
\hline Bi-211 & 8.07E-06 & $1.56 \mathrm{E}-07$ & \\
\hline Bi-212 & $1.19 \mathrm{E}-03$ & $2.30 \mathrm{E}-05$ & \\
\hline Bi-213 & $2.35 \mathrm{E}-03$ & 4.54E-05 & \\
\hline Bi-214 & $1.09 \mathrm{E}-04$ & $2.11 \mathrm{E}-06$ & \\
\hline Bi-215 & $6.48 \mathrm{E}-12$ & $1.25 \mathrm{E}-13$ & \\
\hline Bk-247 & 2.67E-04 & $5.16 \mathrm{E}-06$ & \\
\hline Cd-113 & $8.54 \mathrm{E}-18$ & $1.65 \mathrm{E}-19$ & \\
\hline $\mathrm{Cd}-113 \mathrm{~m}$ & $4.46 \mathrm{E}-13$ & $8.60 \mathrm{E}-15$ & \\
\hline Cf-249 & 7.14E-04 & $1.38 \mathrm{E}-05$ & \\
\hline Cf-250 & $4.76 \mathrm{E}-19$ & $9.19 \mathrm{E}-21$ & \\
\hline Cf-251 & $3.20 \mathrm{E}-03$ & $6.18 \mathrm{E}-05$ & \\
\hline Cf- 252 & $4.94 \mathrm{E}-71$ & $9.54 \mathrm{E}-73$ & \\
\hline $\mathrm{Cl}-36$ & $4.06 \mathrm{E}-03$ & $7.85 \mathrm{E}-05$ & \\
\hline $\mathrm{Cm}-242$ & $1.39 \mathrm{E}-03$ & 2.69E-05 & \\
\hline $\mathrm{Cm}-243$ & $2.57 \mathrm{E}-07$ & 4.97E-09 & \\
\hline $\mathrm{Cm}-244$ & $1.49 \mathrm{E}-09$ & $2.88 \mathrm{E}-11$ & \\
\hline $\mathrm{Cm}-245$ & $2.57 \mathrm{E}-03$ & $4.96 \mathrm{E}-05$ & \\
\hline $\mathrm{Cm}-246$ & $6.04 \mathrm{E}-03$ & $1.17 \mathrm{E}-04$ & Yes \\
\hline $\mathrm{Cm}-247$ & $1.39 \mathrm{E}-07$ & $2.68 \mathrm{E}-09$ & \\
\hline $\mathrm{Cm}-248$ & $1.39 \mathrm{E}-06$ & $2.68 \mathrm{E}-08$ & \\
\hline Co-60 & $1.01 \mathrm{E}-34$ & $1.95 \mathrm{E}-36$ & \\
\hline Cs-135 & $3.32 \mathrm{E}-03$ & $6.41 \mathrm{E}-05$ & \\
\hline Cs-137 & $5.84 \mathrm{E}-04$ & $1.13 \mathrm{E}-05$ & \\
\hline Eu-154 & $1.04 \mathrm{E}-20$ & $2.02 \mathrm{E}-22$ & \\
\hline Eu-155 & $2.15 \mathrm{E}-38$ & 4.16E-40 & \\
\hline Fr-221 & $2.35 \mathrm{E}-03$ & 4.54E-05 & \\
\hline Fr-223 & $1.11 \mathrm{E}-07$ & $2.15 \mathrm{E}-09$ & \\
\hline $\mathrm{Hg}-206$ & $1.93 \mathrm{E}-12$ & $3.72 \mathrm{E}-14$ & \\
\hline I-129 & $1.06 \mathrm{E}-03$ & $2.05 \mathrm{E}-05$ & \\
\hline $\mathrm{Nb}-93 \mathrm{~m}$ & $4.51 \mathrm{E}-01$ & 8.71E-03 & Yes \\
\hline $\mathrm{Ni}-59$ & $2.56 \mathrm{E}+00$ & 4.93E-02 & Yes \\
\hline $\mathrm{Ni}-63$ & $2.51 \mathrm{E}+00$ & $4.85 \mathrm{E}-02$ & Yes \\
\hline Np-237 & $2.93 \mathrm{E}-02$ & $5.65 \mathrm{E}-04$ & Yes \\
\hline Np-238 & 7.77E-06 & $1.50 \mathrm{E}-07$ & \\
\hline Np-239 & $4.72 \mathrm{E}-01$ & $9.10 \mathrm{E}-03$ & \\
\hline Np-240 & $6.63 \mathrm{E}-12$ & $1.28 \mathrm{E}-13$ & \\
\hline $\mathrm{Pa}-231$ & $8.48 \mathrm{E}-06$ & $1.64 \mathrm{E}-07$ & \\
\hline $\mathrm{Pa}-233$ & 2.93E-02 & $5.65 \mathrm{E}-04$ & \\
\hline $\mathrm{Pa}-234$ & $2.40 \mathrm{E}-05$ & 4.63E-07 & \\
\hline Pa-234m & $1.60 \mathrm{E}-02$ & $3.09 \mathrm{E}-04$ & \\
\hline Pb-209 & $2.35 \mathrm{E}-03$ & $4.54 \mathrm{E}-05$ & \\
\hline $\mathrm{Pb}-210$ & $1.02 \mathrm{E}-04$ & $1.96 \mathrm{E}-06$ & \\
\hline $\mathrm{Pb}-211$ & $8.07 \mathrm{E}-06$ & $1.56 \mathrm{E}-07$ & \\
\hline $\mathrm{Pb}-212$ & $1.19 \mathrm{E}-03$ & $2.30 \mathrm{E}-05$ & \\
\hline $\mathrm{Pb}-214$ & $1.09 \mathrm{E}-04$ & $2.11 \mathrm{E}-06$ & \\
\hline
\end{tabular}

\begin{tabular}{|c|c|c|c|}
\hline Nuclide & $\begin{array}{l}Y 2615 \\
\mu \mathrm{Ci} / \mathrm{g}\end{array}$ & $\begin{array}{c}\text { Fraction of } \\
\text { Activity }\end{array}$ & Reportable \\
\hline Pd-107 & $1.22 \mathrm{E}-03$ & $2.36 \mathrm{E}-05$ & \\
\hline Pm-147 & $1.11 \mathrm{E}-67$ & $2.15 \mathrm{E}-69$ & \\
\hline Po-210 & $1.01 \mathrm{E}-04$ & $1.96 \mathrm{E}-06$ & \\
\hline Po-211 & $2.20 \mathrm{E}-08$ & $4.25 \mathrm{E}-10$ & \\
\hline Po-212 & 7.62E-04 & $1.47 \mathrm{E}-05$ & \\
\hline Po-213 & $2.30 \mathrm{E}-03$ & $4.45 \mathrm{E}-05$ & \\
\hline Рo-214 & 1.09E-04 & $2.11 \mathrm{E}-06$ & \\
\hline Po-215 & $8.07 \mathrm{E}-06$ & $1.56 \mathrm{E}-07$ & \\
\hline Po-216 & $1.19 \mathrm{E}-03$ & $2.30 \mathrm{E}-05$ & \\
\hline Po-218 & $1.09 \mathrm{E}-04$ & $2.11 \mathrm{E}-06$ & \\
\hline $\mathrm{Pu}-238$ & $1.21 \mathrm{E}+00$ & $2.34 \mathrm{E}-02$ & Yes \\
\hline $\mathrm{Pu}-239$ & $1.06 \mathrm{E}+01$ & $2.05 \mathrm{E}-01$ & Yes \\
\hline $\mathrm{Pu}-240$ & $3.42 \mathrm{E}+00$ & $6.59 \mathrm{E}-02$ & Yes \\
\hline $\mathrm{Pu}-241$ & $2.57 \mathrm{E}-03$ & $4.97 \mathrm{E}-05$ & \\
\hline $\mathrm{Pu}-242$ & 8.98E-03 & $1.73 \mathrm{E}-04$ & Yes \\
\hline $\mathrm{Pu}-243$ & $1.39 \mathrm{E}-07$ & $2.68 \mathrm{E}-09$ & \\
\hline $\mathrm{Pu}-244$ & $6.64 \mathrm{E}-12$ & $1.28 \mathrm{E}-13$ & \\
\hline Ra-223 & 8.07E-06 & $1.56 \mathrm{E}-07$ & \\
\hline Ra-224 & 1.19E-03 & $2.30 \mathrm{E}-05$ & \\
\hline Ra-225 & $2.35 \mathrm{E}-03$ & $4.54 \mathrm{E}-05$ & \\
\hline Ra-226 & $1.09 \mathrm{E}-04$ & $2.11 \mathrm{E}-06$ & \\
\hline Ra-228 & $1.19 \mathrm{E}-03$ & $2.30 \mathrm{E}-05$ & \\
\hline $\mathrm{Rn}-217$ & $2.83 \mathrm{E}-07$ & $5.45 \mathrm{E}-09$ & \\
\hline Rn-218 & $2.08 \mathrm{E}-11$ & $4.01 \mathrm{E}-13$ & \\
\hline Rn-219 & 8.07E-06 & $1.56 \mathrm{E}-07$ & \\
\hline Rn-220 & $1.19 \mathrm{E}-03$ & $2.30 \mathrm{E}-05$ & \\
\hline Rn-222 & $1.09 \mathrm{E}-04$ & $2.11 \mathrm{E}-06$ & \\
\hline Sb-125 & $5.74 \mathrm{E}-67$ & $1.11 \mathrm{E}-68$ & \\
\hline $\mathrm{Sb}-126$ & $9.82 \mathrm{E}-02$ & $1.90 \mathrm{E}-03$ & \\
\hline $\mathrm{Sb}-126 \mathrm{~m}$ & $7.02 \mathrm{E}-01$ & $1.35 \mathrm{E}-02$ & \\
\hline Sb-126m2 & $4.70 \mathrm{E}-01$ & $9.07 \mathrm{E}-03$ & \\
\hline Se-79 & $1.54 \mathrm{E}-02$ & 2.97E-04 & Yes \\
\hline Sm-147 & $4.28 \mathrm{E}-09$ & $8.27 \mathrm{E}-11$ & \\
\hline Sm-151 & $2.38 \mathrm{E}+00$ & $4.59 \mathrm{E}-02$ & Yes \\
\hline Sn-121 & $1.92 \mathrm{E}-04$ & $3.71 \mathrm{E}-06$ & \\
\hline $\mathrm{Sn}-121 \mathrm{~m}$ & $2.48 \mathrm{E}-04$ & 4.79E-06 & \\
\hline Sn-126 & $7.02 \mathrm{E}-01$ & $1.35 \mathrm{E}-02$ & Yes \\
\hline Sr-90 & $6.29 \mathrm{E}-03$ & $1.21 \mathrm{E}-04$ & Yes \\
\hline Tc-99 & $9.65 \mathrm{E}-02$ & $1.86 \mathrm{E}-03$ & Yes \\
\hline $\mathrm{Te}-125 \mathrm{~m}$ & $1.36 \mathrm{E}-67$ & 2.63E-69 & \\
\hline Th-227 & $7.96 \mathrm{E}-06$ & $1.54 \mathrm{E}-07$ & \\
\hline Th-228 & $1.19 \mathrm{E}-03$ & $2.30 \mathrm{E}-05$ & \\
\hline Th-229 & $2.36 \mathrm{E}-03$ & $4.55 \mathrm{E}-05$ & \\
\hline Th-230 & $6.87 \mathrm{E}-04$ & $1.33 \mathrm{E}-05$ & \\
\hline Th-231 & $6.18 \mathrm{E}-04$ & 1.19E-05 & \\
\hline Th-232 & $1.19 \mathrm{E}-03$ & $2.30 \mathrm{E}-05$ & \\
\hline Th-234 & $1.60 \mathrm{E}-02$ & 3.09E-04 & \\
\hline Tl-206 & $1.36 \mathrm{E}-10$ & $2.62 \mathrm{E}-12$ & \\
\hline Tl-207 & $8.05 \mathrm{E}-06$ & $1.55 \mathrm{E}-07$ & \\
\hline Tl-208 & $4.28 \mathrm{E}-04$ & $8.26 \mathrm{E}-06$ & \\
\hline Tl-209 & $5.09 \mathrm{E}-05$ & $9.82 \mathrm{E}-07$ & \\
\hline $\mathrm{Tl}-210$ & $2.29 \mathrm{E}-08$ & $4.43 \mathrm{E}-10$ & \\
\hline U-233 & $4.22 \mathrm{E}-02$ & $8.14 \mathrm{E}-04$ & Yes \\
\hline U-234 & $9.08 \mathrm{E}-02$ & $1.75 \mathrm{E}-03$ & Yes \\
\hline U-235 & $6.18 \mathrm{E}-04$ & $1.19 \mathrm{E}-05$ & \\
\hline $\mathrm{U}-235 \mathrm{~m}$ & $1.06 \mathrm{E}+01$ & $2.05 \mathrm{E}-01$ & \\
\hline U-236 & $9.65 \mathrm{E}-04$ & $1.86 \mathrm{E}-05$ & \\
\hline U-237 & $6.33 \mathrm{E}-08$ & $1.22 \mathrm{E}-09$ & \\
\hline U-238 & $1.60 \mathrm{E}-02$ & 3.09E-04 & Yes \\
\hline $\mathrm{U}-240$ & $6.63 \mathrm{E}-12$ & $1.28 \mathrm{E}-13$ & \\
\hline Y-90 & $6.29 \mathrm{E}-03$ & $1.22 \mathrm{E}-04$ & \\
\hline Zr-93 & $4.63 \mathrm{E}-01$ & 8.94E-03 & Yes \\
\hline TOTAL & $5.18 \mathrm{E}+01$ & $1.00 \mathrm{E}+00$ & \\
\hline
\end{tabular}




\section{APPENDIX H. ACTIVITIES OF DRIED SLUDGE IN YEAR $2715(\mu \mathrm{Ci} / \mathrm{g})$}


SRNL-STI-2012-00294

Revision 0

\begin{tabular}{|c|c|c|c|}
\hline Nuclide & $\begin{array}{l}\text { Y } 2715 \\
\mu \mathrm{Ci} / \mathrm{g}\end{array}$ & $\begin{array}{c}\text { Fraction of } \\
\text { Activity }\end{array}$ & Reportable \\
\hline Ac-225 & $2.73 \mathrm{E}-03$ & $5.88 \mathrm{E}-05$ & \\
\hline Ac-227 & $9.36 \mathrm{E}-06$ & $2.02 \mathrm{E}-07$ & \\
\hline Ac- 228 & $1.19 \mathrm{E}-03$ & $2.57 \mathrm{E}-05$ & \\
\hline Am-241 & $1.21 \mathrm{E}+01$ & $2.61 \mathrm{E}-01$ & Yes \\
\hline Am-242 & $1.02 \mathrm{E}-03$ & $2.20 \mathrm{E}-05$ & \\
\hline Am- $242 m$ & $1.03 \mathrm{E}-03$ & $2.21 \mathrm{E}-05$ & \\
\hline Am-243 & $4.67 \mathrm{E}-01$ & $1.01 \mathrm{E}-02$ & Yes \\
\hline At-215 & $3.74 \mathrm{E}-11$ & $8.07 \mathrm{E}-13$ & \\
\hline At-217 & $2.73 \mathrm{E}-03$ & $5.88 \mathrm{E}-05$ & \\
\hline At-218 & $2.57 \mathrm{E}-08$ & $5.55 \mathrm{E}-10$ & \\
\hline At-219 & $7.75 \mathrm{E}-12$ & $1.67 \mathrm{E}-13$ & \\
\hline Ba-133 & $1.56 \mathrm{E}-21$ & $3.37 \mathrm{E}-23$ & \\
\hline Ba-137m & 5.49E-05 & $1.18 \mathrm{E}-06$ & \\
\hline Bi-209 & $3.56 \mathrm{E}-20$ & $7.68 \mathrm{E}-22$ & \\
\hline Bi-210 & $1.27 \mathrm{E}-04$ & 2.74E-06 & \\
\hline Bi-211 & $9.36 \mathrm{E}-06$ & $2.02 \mathrm{E}-07$ & \\
\hline Bi-212 & 1.19E-03 & $2.57 \mathrm{E}-05$ & \\
\hline Bi-213 & $2.73 \mathrm{E}-03$ & $5.88 \mathrm{E}-05$ & \\
\hline Bi-214 & $1.36 \mathrm{E}-04$ & 2.92E-06 & \\
\hline $\mathrm{Bi}-215$ & $7.52 \mathrm{E}-12$ & $1.62 \mathrm{E}-13$ & \\
\hline Bk-247 & $2.54 \mathrm{E}-04$ & $5.48 \mathrm{E}-06$ & \\
\hline Cd-113 & $8.54 \mathrm{E}-18$ & $1.84 \mathrm{E}-19$ & \\
\hline Cd-113m & $3.27 \mathrm{E}-15$ & 7.04E-17 & \\
\hline Cf-249 & $5.86 \mathrm{E}-04$ & $1.26 \mathrm{E}-05$ & \\
\hline Cf- 250 & $2.38 \mathrm{E}-21$ & $5.13 \mathrm{E}-23$ & \\
\hline Cf-251 & $2.96 \mathrm{E}-03$ & 6.39E-05 & \\
\hline Cf- 252 & $2.06 \mathrm{E}-82$ & $4.44 \mathrm{E}-84$ & \\
\hline $\mathrm{Cl}-36$ & $4.06 \mathrm{E}-03$ & 8.76E-05 & \\
\hline $\mathrm{Cm}-242$ & $8.52 \mathrm{E}-04$ & $1.84 \mathrm{E}-05$ & \\
\hline $\mathrm{Cm}-243$ & $2.55 \mathrm{E}-08$ & $5.50 \mathrm{E}-10$ & \\
\hline $\mathrm{Cm}-244$ & $3.17 \mathrm{E}-11$ & $6.83 \mathrm{E}-13$ & \\
\hline $\mathrm{Cm}-245$ & $2.55 \mathrm{E}-03$ & $5.51 \mathrm{E}-05$ & \\
\hline $\mathrm{Cm}-246$ & $5.95 \mathrm{E}-03$ & $1.28 \mathrm{E}-04$ & Yes \\
\hline $\mathrm{Cm}-247$ & $1.52 \mathrm{E}-07$ & 3.29E-09 & \\
\hline $\mathrm{Cm}-248$ & $1.39 \mathrm{E}-06$ & 2.99E-08 & \\
\hline Co-60 & $1.96 \mathrm{E}-40$ & 4.23E-42 & \\
\hline Cs- 135 & $3.32 \mathrm{E}-03$ & $7.16 \mathrm{E}-05$ & \\
\hline Cs-137 & $5.81 \mathrm{E}-05$ & $1.25 \mathrm{E}-06$ & \\
\hline Eu-154 & $3.28 \mathrm{E}-24$ & 7.07E-26 & \\
\hline Eu-155 & $9.99 \mathrm{E}-45$ & $2.15 \mathrm{E}-46$ & \\
\hline Fr-221 & $2.73 \mathrm{E}-03$ & $5.88 \mathrm{E}-05$ & \\
\hline Fr-223 & $1.29 \mathrm{E}-07$ & 2.79E-09 & \\
\hline $\mathrm{Hg}-206$ & $2.41 \mathrm{E}-12$ & $5.20 \mathrm{E}-14$ & \\
\hline I-129 & $1.06 \mathrm{E}-03$ & $2.29 \mathrm{E}-05$ & \\
\hline $\mathrm{Nb}-93 \mathrm{~m}$ & $4.51 \mathrm{E}-01$ & $9.73 \mathrm{E}-03$ & Yes \\
\hline $\mathrm{Ni}-59$ & $2.55 \mathrm{E}+00$ & $5.51 \mathrm{E}-02$ & Yes \\
\hline $\mathrm{Ni}-63$ & $1.26 \mathrm{E}+00$ & $2.72 \mathrm{E}-02$ & Yes \\
\hline Np-237 & $2.97 \mathrm{E}-02$ & $6.40 \mathrm{E}-04$ & Yes \\
\hline Np-238 & $4.75 \mathrm{E}-06$ & $1.02 \mathrm{E}-07$ & \\
\hline Np-239 & $4.67 \mathrm{E}-01$ & $1.01 \mathrm{E}-02$ & \\
\hline Np-240 & $7.73 \mathrm{E}-12$ & $1.67 \mathrm{E}-13$ & \\
\hline $\mathrm{Pa}-231$ & $9.77 \mathrm{E}-06$ & $2.11 \mathrm{E}-07$ & \\
\hline $\mathrm{Pa}-233$ & $2.97 \mathrm{E}-02$ & $6.40 \mathrm{E}-04$ & \\
\hline $\mathrm{Pa}-234$ & $2.40 \mathrm{E}-05$ & $5.17 \mathrm{E}-07$ & \\
\hline $\mathrm{Pa}-234 \mathrm{~m}$ & $1.60 \mathrm{E}-02$ & $3.45 \mathrm{E}-04$ & \\
\hline Pb-209 & $2.73 \mathrm{E}-03$ & $5.88 \mathrm{E}-05$ & \\
\hline $\mathrm{Pb}-210$ & $1.27 \mathrm{E}-04$ & $2.74 \mathrm{E}-06$ & \\
\hline $\mathrm{Pb}-211$ & $9.36 \mathrm{E}-06$ & $2.02 \mathrm{E}-07$ & \\
\hline $\mathrm{Pb}-212$ & 1.19E-03 & $2.57 \mathrm{E}-05$ & \\
\hline $\mathrm{Pb}-214$ & $1.35 \mathrm{E}-04$ & $2.92 \mathrm{E}-06$ & \\
\hline
\end{tabular}

\begin{tabular}{|c|c|c|c|}
\hline Nuclide & $\begin{array}{l}\text { Y } 2715 \\
\mu \mathrm{Ci} / \mathrm{g}\end{array}$ & $\begin{array}{c}\text { Fraction of } \\
\text { Activity }\end{array}$ & Reportable \\
\hline Pd-107 & $1.22 \mathrm{E}-03$ & $2.63 \mathrm{E}-05$ & \\
\hline Pm-147 & $3.74 \mathrm{E}-79$ & $8.06 \mathrm{E}-81$ & \\
\hline Po-210 & $1.27 \mathrm{E}-04$ & $2.73 \mathrm{E}-06$ & \\
\hline Po-211 & $2.56 \mathrm{E}-08$ & $5.51 \mathrm{E}-10$ & \\
\hline Po-212 & 7.62E-04 & $1.64 \mathrm{E}-05$ & \\
\hline Po-213 & $2.67 \mathrm{E}-03$ & $5.75 \mathrm{E}-05$ & \\
\hline Po-214 & $1.35 \mathrm{E}-04$ & $2.92 \mathrm{E}-06$ & \\
\hline Po-215 & $9.36 \mathrm{E}-06$ & $2.02 \mathrm{E}-07$ & \\
\hline Po-216 & $1.19 \mathrm{E}-03$ & $2.57 \mathrm{E}-05$ & \\
\hline Po-218 & $1.36 \mathrm{E}-04$ & $2.92 \mathrm{E}-06$ & \\
\hline $\mathrm{Pu}-238$ & $5.51 \mathrm{E}-01$ & 1.19E-02 & Yes \\
\hline $\mathrm{Pu}-239$ & $1.06 \mathrm{E}+01$ & $2.28 \mathrm{E}-01$ & Yes \\
\hline $\mathrm{Pu}-240$ & $3.38 \mathrm{E}+00$ & $7.29 \mathrm{E}-02$ & Yes \\
\hline $\mathrm{Pu}-241$ & $2.56 \mathrm{E}-03$ & $5.51 \mathrm{E}-05$ & \\
\hline $\mathrm{Pu}-242$ & $8.98 \mathrm{E}-03$ & $1.94 \mathrm{E}-04$ & Yes \\
\hline $\mathrm{Pu}-243$ & $1.52 \mathrm{E}-07$ & $3.29 \mathrm{E}-09$ & \\
\hline $\mathrm{Pu}-244$ & $7.74 \mathrm{E}-12$ & $1.67 \mathrm{E}-13$ & \\
\hline Ra-223 & $9.36 \mathrm{E}-06$ & 2.02E-07 & \\
\hline $\mathrm{Ra}-224$ & $1.19 \mathrm{E}-03$ & $2.57 \mathrm{E}-05$ & \\
\hline $\mathrm{Ra}-225$ & $2.73 \mathrm{E}-03$ & $5.88 \mathrm{E}-05$ & \\
\hline $\mathrm{Ra}-226$ & $1.36 \mathrm{E}-04$ & $2.92 \mathrm{E}-06$ & \\
\hline $\mathrm{Ra}-228$ & $1.19 \mathrm{E}-03$ & $2.57 \mathrm{E}-05$ & \\
\hline Rn-217 & $3.27 \mathrm{E}-07$ & 7.06E-09 & \\
\hline $\mathrm{Rn}-218$ & $2.57 \mathrm{E}-11$ & $5.55 \mathrm{E}-13$ & \\
\hline Rn-219 & $9.36 \mathrm{E}-06$ & $2.02 \mathrm{E}-07$ & \\
\hline $\mathrm{Rn}-220$ & $1.19 \mathrm{E}-03$ & $2.57 \mathrm{E}-05$ & \\
\hline Rn-222 & $1.36 \mathrm{E}-04$ & $2.92 \mathrm{E}-06$ & \\
\hline Sb-125 & $7.02 \mathrm{E}-78$ & $1.51 \mathrm{E}-79$ & \\
\hline Sb-126 & $9.82 \mathrm{E}-02$ & $2.12 \mathrm{E}-03$ & \\
\hline Sb-126m & $7.02 \mathrm{E}-01$ & $1.51 \mathrm{E}-02$ & \\
\hline $\mathrm{Sb}-126 \mathrm{~m} 2$ & $4.70 \mathrm{E}-01$ & $1.01 \mathrm{E}-02$ & \\
\hline Se-79 & $1.54 \mathrm{E}-02$ & $3.32 \mathrm{E}-04$ & Yes \\
\hline Sm-147 & $4.28 \mathrm{E}-09$ & $9.23 \mathrm{E}-11$ & \\
\hline Sm-151 & $1.10 \mathrm{E}+00$ & $2.37 \mathrm{E}-02$ & Yes \\
\hline Sn- 121 & $5.46 \mathrm{E}-05$ & $1.18 \mathrm{E}-06$ & \\
\hline Sn-121m & $7.03 \mathrm{E}-05$ & $1.52 \mathrm{E}-06$ & \\
\hline Sn-126 & 7.02E-01 & $1.51 \mathrm{E}-02$ & Yes \\
\hline $\mathrm{Sr}-90$ & $5.67 \mathrm{E}-04$ & $1.22 \mathrm{E}-05$ & \\
\hline Tc-99 & $9.65 \mathrm{E}-02$ & $2.08 \mathrm{E}-03$ & Yes \\
\hline $\mathrm{Te}-125 \mathrm{~m}$ & $1.67 \mathrm{E}-78$ & $3.59 \mathrm{E}-80$ & \\
\hline Th-227 & $9.23 \mathrm{E}-06$ & $1.99 \mathrm{E}-07$ & \\
\hline Th-228 & $1.19 \mathrm{E}-03$ & $2.57 \mathrm{E}-05$ & \\
\hline Th-229 & $2.73 \mathrm{E}-03$ & $5.88 \mathrm{E}-05$ & \\
\hline Th-230 & $7.70 \mathrm{E}-04$ & $1.66 \mathrm{E}-05$ & \\
\hline Th-231 & $6.19 \mathrm{E}-04$ & $1.34 \mathrm{E}-05$ & \\
\hline Th-232 & $1.19 \mathrm{E}-03$ & $2.57 \mathrm{E}-05$ & \\
\hline Th-234 & $1.60 \mathrm{E}-02$ & $3.45 \mathrm{E}-04$ & \\
\hline Tl-206 & $1.70 \mathrm{E}-10$ & $3.66 \mathrm{E}-12$ & \\
\hline Tl-207 & $9.33 \mathrm{E}-06$ & $2.01 \mathrm{E}-07$ & \\
\hline Tl-208 & $4.28 \mathrm{E}-04$ & $9.22 \mathrm{E}-06$ & \\
\hline Tl-209 & $5.89 \mathrm{E}-05$ & $1.27 \mathrm{E}-06$ & \\
\hline Tl-210 & $2.85 \mathrm{E}-08$ & $6.13 \mathrm{E}-10$ & \\
\hline U-233 & $4.22 \mathrm{E}-02$ & $9.09 \mathrm{E}-04$ & Yes \\
\hline U-234 & $9.10 \mathrm{E}-02$ & $1.96 \mathrm{E}-03$ & Yes \\
\hline U-235 & $6.19 \mathrm{E}-04$ & $1.34 \mathrm{E}-05$ & \\
\hline U-235m & $1.06 \mathrm{E}+01$ & $2.28 \mathrm{E}-01$ & \\
\hline U-236 & $9.75 \mathrm{E}-04$ & $2.10 \mathrm{E}-05$ & \\
\hline U-237 & $6.29 \mathrm{E}-08$ & $1.36 \mathrm{E}-09$ & \\
\hline U-238 & $1.60 \mathrm{E}-02$ & $3.45 \mathrm{E}-04$ & Yes \\
\hline U-240 & $7.73 \mathrm{E}-12$ & $1.67 \mathrm{E}-13$ & \\
\hline Y-90 & $5.67 \mathrm{E}-04$ & $1.22 \mathrm{E}-05$ & \\
\hline Zr-93 & $4.63 \mathrm{E}-01$ & $9.98 \mathrm{E}-03$ & Yes \\
\hline TOTAL & $4.64 \mathrm{E}+01$ & $1.00 \mathrm{E}+00$ & \\
\hline
\end{tabular}




\section{APPENDIX I. ACTIVITIES OF DRIED SLUDGE IN YEAR $2815(\mu \mathrm{Ci} / \mathrm{g})$}


SRNL-STI-2012-00294

Revision 0

\begin{tabular}{|c|c|c|c|}
\hline Nuclide & $\begin{array}{l}\mathrm{Y} 2815 \\
\mu \mathrm{Ci} / \mathrm{g}\end{array}$ & $\begin{array}{c}\text { Fraction of } \\
\text { Activity }\end{array}$ & Reportable \\
\hline Ac-225 & $3.10 \mathrm{E}-03$ & $7.21 \mathrm{E}-05$ & \\
\hline Ac-227 & $1.07 \mathrm{E}-05$ & $2.48 \mathrm{E}-07$ & \\
\hline Ac- 228 & $1.19 \mathrm{E}-03$ & 2.77E-05 & \\
\hline Am-241 & $1.03 \mathrm{E}+01$ & $2.40 \mathrm{E}-01$ & Yes \\
\hline Am-242 & $6.25 \mathrm{E}-04$ & $1.45 \mathrm{E}-05$ & \\
\hline Am- $242 m$ & $6.27 \mathrm{E}-04$ & $1.46 \mathrm{E}-05$ & \\
\hline Am-243 & $4.63 \mathrm{E}-01$ & $1.08 \mathrm{E}-02$ & Yes \\
\hline At-215 & $4.26 \mathrm{E}-11$ & $9.91 \mathrm{E}-13$ & \\
\hline At-217 & $3.10 \mathrm{E}-03$ & $7.21 \mathrm{E}-05$ & \\
\hline At-218 & $3.12 \mathrm{E}-08$ & $7.26 \mathrm{E}-10$ & \\
\hline At-219 & $8.82 \mathrm{E}-12$ & $2.05 \mathrm{E}-13$ & \\
\hline Ba-133 & $2.18 \mathrm{E}-24$ & $5.06 \mathrm{E}-26$ & \\
\hline Ba-137m & $5.46 \mathrm{E}-06$ & $1.27 \mathrm{E}-07$ & \\
\hline Bi-209 & $4.63 \mathrm{E}-20$ & $1.08 \mathrm{E}-21$ & \\
\hline Bi-210 & $1.55 \mathrm{E}-04$ & $3.60 \mathrm{E}-06$ & \\
\hline Bi-211 & $1.07 \mathrm{E}-05$ & $2.48 \mathrm{E}-07$ & \\
\hline Bi-212 & 1.19E-03 & $2.77 \mathrm{E}-05$ & \\
\hline Bi-213 & $3.10 \mathrm{E}-03$ & $7.21 \mathrm{E}-05$ & \\
\hline Bi-214 & 1.64E-04 & $3.82 \mathrm{E}-06$ & \\
\hline $\mathrm{Bi}-215$ & $8.55 \mathrm{E}-12$ & $1.99 \mathrm{E}-13$ & \\
\hline Bk-247 & $2.42 \mathrm{E}-04$ & $5.63 \mathrm{E}-06$ & \\
\hline Cd-113 & $8.54 \mathrm{E}-18$ & $1.99 \mathrm{E}-19$ & \\
\hline Cd-113m & $2.39 \mathrm{E}-17$ & $5.57 \mathrm{E}-19$ & \\
\hline Cf-249 & $4.81 \mathrm{E}-04$ & $1.12 \mathrm{E}-05$ & \\
\hline Cf-250 & $1.19 \mathrm{E}-23$ & $2.76 \mathrm{E}-25$ & \\
\hline Cf-251 & $2.74 \mathrm{E}-03$ & 6.39E-05 & \\
\hline Cf- 252 & 8.56E-94 & $1.99 \mathrm{E}-95$ & \\
\hline $\mathrm{Cl}-36$ & $4.06 \mathrm{E}-03$ & $9.45 \mathrm{E}-05$ & \\
\hline $\mathrm{Cm}-242$ & $5.21 \mathrm{E}-04$ & $1.21 \mathrm{E}-05$ & \\
\hline $\mathrm{Cm}-243$ & $2.53 \mathrm{E}-09$ & $5.89 \mathrm{E}-11$ & \\
\hline $\mathrm{Cm}-244$ & $6.74 \mathrm{E}-13$ & $1.57 \mathrm{E}-14$ & \\
\hline $\mathrm{Cm}-245$ & $2.54 \mathrm{E}-03$ & $5.90 \mathrm{E}-05$ & \\
\hline $\mathrm{Cm}-246$ & $5.87 \mathrm{E}-03$ & $1.37 \mathrm{E}-04$ & Yes \\
\hline $\mathrm{Cm}-247$ & $1.65 \mathrm{E}-07$ & 3.83E-09 & \\
\hline $\mathrm{Cm}-248$ & $1.39 \mathrm{E}-06$ & $3.22 \mathrm{E}-08$ & \\
\hline Co-60 & $3.82 \mathrm{E}-46$ & $8.88 \mathrm{E}-48$ & \\
\hline Cs- 135 & $3.32 \mathrm{E}-03$ & 7.72E-05 & \\
\hline Cs-137 & $5.78 \mathrm{E}-06$ & $1.35 \mathrm{E}-07$ & \\
\hline Eu-154 & $1.03 \mathrm{E}-27$ & 2.39E-29 & \\
\hline Eu-155 & 4.64E-51 & $1.08 \mathrm{E}-52$ & \\
\hline Fr-221 & $3.10 \mathrm{E}-03$ & $7.21 \mathrm{E}-05$ & \\
\hline Fr-223 & $1.47 \mathrm{E}-07$ & $3.42 \mathrm{E}-09$ & \\
\hline $\mathrm{Hg}-206$ & $2.94 \mathrm{E}-12$ & $6.85 \mathrm{E}-14$ & \\
\hline I-129 & $1.06 \mathrm{E}-03$ & $2.47 \mathrm{E}-05$ & \\
\hline $\mathrm{Nb}-93 \mathrm{~m}$ & $4.51 \mathrm{E}-01$ & $1.05 \mathrm{E}-02$ & Yes \\
\hline $\mathrm{Ni}-59$ & $2.55 \mathrm{E}+00$ & $5.94 \mathrm{E}-02$ & Yes \\
\hline $\mathrm{Ni}-63$ & $6.33 \mathrm{E}-01$ & $1.47 \mathrm{E}-02$ & Yes \\
\hline Np-237 & 3.01E-02 & $6.99 \mathrm{E}-04$ & Yes \\
\hline Np-238 & $2.91 \mathrm{E}-06$ & $6.76 \mathrm{E}-08$ & \\
\hline Np-239 & $4.63 \mathrm{E}-01$ & $1.08 \mathrm{E}-02$ & \\
\hline Np-240 & $8.83 \mathrm{E}-12$ & $2.06 \mathrm{E}-13$ & \\
\hline $\mathrm{Pa}-231$ & $1.11 \mathrm{E}-05$ & $2.57 \mathrm{E}-07$ & \\
\hline $\mathrm{Pa}-233$ & $3.01 \mathrm{E}-02$ & 6.99E-04 & \\
\hline $\mathrm{Pa}-234$ & $2.40 \mathrm{E}-05$ & $5.59 \mathrm{E}-07$ & \\
\hline $\mathrm{Pa}-234 \mathrm{~m}$ & $1.60 \mathrm{E}-02$ & $3.72 \mathrm{E}-04$ & \\
\hline Pb-209 & $3.10 \mathrm{E}-03$ & $7.21 \mathrm{E}-05$ & \\
\hline $\mathrm{Pb}-210$ & $1.55 \mathrm{E}-04$ & $3.60 \mathrm{E}-06$ & \\
\hline $\mathrm{Pb}-211$ & $1.07 \mathrm{E}-05$ & $2.48 \mathrm{E}-07$ & \\
\hline $\mathrm{Pb}-212$ & 1.19E-03 & $2.77 \mathrm{E}-05$ & \\
\hline $\mathrm{Pb}-214$ & $1.64 \mathrm{E}-04$ & $3.82 \mathrm{E}-06$ & \\
\hline
\end{tabular}

\begin{tabular}{|c|c|c|c|}
\hline Nuclide & $\begin{array}{l}\text { Y } 2815 \\
\mu \mathrm{Ci} / \mathrm{g}\end{array}$ & $\begin{array}{c}\text { Fraction of } \\
\text { Activity }\end{array}$ & Reportable \\
\hline Pd-107 & $1.22 \mathrm{E}-03$ & $2.84 \mathrm{E}-05$ & \\
\hline Pm-147 & $1.25 \mathrm{E}-90$ & 2.92E-92 & \\
\hline Po-210 & $1.55 \mathrm{E}-04$ & $3.60 \mathrm{E}-06$ & \\
\hline Po-211 & $2.91 \mathrm{E}-08$ & $6.77 \mathrm{E}-10$ & \\
\hline Po-212 & 7.62E-04 & $1.77 \mathrm{E}-05$ & \\
\hline Po-213 & $3.03 \mathrm{E}-03$ & $7.06 \mathrm{E}-05$ & \\
\hline Po-214 & $1.64 \mathrm{E}-04$ & $3.82 \mathrm{E}-06$ & \\
\hline Po-215 & $1.07 \mathrm{E}-05$ & $2.48 \mathrm{E}-07$ & \\
\hline Po-216 & $1.19 \mathrm{E}-03$ & $2.77 \mathrm{E}-05$ & \\
\hline Po-218 & $1.64 \mathrm{E}-04$ & $3.82 \mathrm{E}-06$ & \\
\hline $\mathrm{Pu}-238$ & $2.50 \mathrm{E}-01$ & $5.82 \mathrm{E}-03$ & Yes \\
\hline $\mathrm{Pu}-239$ & $1.06 \mathrm{E}+01$ & $2.46 \mathrm{E}-01$ & Yes \\
\hline $\mathrm{Pu}-240$ & $3.34 \mathrm{E}+00$ & $7.78 \mathrm{E}-02$ & Yes \\
\hline $\mathrm{Pu}-241$ & $2.54 \mathrm{E}-03$ & $5.91 \mathrm{E}-05$ & \\
\hline $\mathrm{Pu}-242$ & $8.98 \mathrm{E}-03$ & $2.09 \mathrm{E}-04$ & Yes \\
\hline $\mathrm{Pu}-243$ & $1.65 \mathrm{E}-07$ & 3.83E-09 & \\
\hline $\mathrm{Pu}-244$ & $8.84 \mathrm{E}-12$ & $2.06 \mathrm{E}-13$ & \\
\hline $\mathrm{Ra}-223$ & $1.07 \mathrm{E}-05$ & $2.48 \mathrm{E}-07$ & \\
\hline $\mathrm{Ra}-224$ & $1.19 \mathrm{E}-03$ & $2.77 \mathrm{E}-05$ & \\
\hline $\mathrm{Ra}-225$ & $3.10 \mathrm{E}-03$ & $7.21 \mathrm{E}-05$ & \\
\hline Ra-226 & $1.64 \mathrm{E}-04$ & $3.82 \mathrm{E}-06$ & \\
\hline $\mathrm{Ra}-228$ & $1.19 \mathrm{E}-03$ & $2.77 \mathrm{E}-05$ & \\
\hline Rn-217 & $3.72 \mathrm{E}-07$ & $8.66 \mathrm{E}-09$ & \\
\hline $\mathrm{Rn}-218$ & $3.12 \mathrm{E}-11$ & $7.26 \mathrm{E}-13$ & \\
\hline Rn-219 & $1.07 \mathrm{E}-05$ & $2.48 \mathrm{E}-07$ & \\
\hline $\mathrm{Rn}-220$ & $1.19 \mathrm{E}-03$ & $2.77 \mathrm{E}-05$ & \\
\hline Rn-222 & $1.64 \mathrm{E}-04$ & $3.82 \mathrm{E}-06$ & \\
\hline Sb-125 & $8.58 \mathrm{E}-89$ & $2.00 \mathrm{E}-90$ & \\
\hline Sb-126 & $9.82 \mathrm{E}-02$ & $2.29 \mathrm{E}-03$ & \\
\hline Sb-126m & $7.01 \mathrm{E}-01$ & $1.63 \mathrm{E}-02$ & \\
\hline $\mathrm{Sb}-126 \mathrm{~m} 2$ & $4.69 \mathrm{E}-01$ & 1.09E-02 & \\
\hline Se-79 & $1.54 \mathrm{E}-02$ & $3.58 \mathrm{E}-04$ & Yes \\
\hline $\mathrm{Sm}-147$ & $4.28 \mathrm{E}-09$ & $9.97 \mathrm{E}-11$ & \\
\hline Sm-151 & $5.09 \mathrm{E}-01$ & 1.19E-02 & Yes \\
\hline Sn-121 & $1.55 \mathrm{E}-05$ & $3.60 \mathrm{E}-07$ & \\
\hline Sn-121m & $1.99 \mathrm{E}-05$ & 4.64E-07 & \\
\hline Sn-126 & 7.01E-01 & $1.63 \mathrm{E}-02$ & Yes \\
\hline $\mathrm{Sr}-90$ & $5.10 \mathrm{E}-05$ & $1.19 \mathrm{E}-06$ & \\
\hline Tc-99 & $9.65 \mathrm{E}-02$ & $2.24 \mathrm{E}-03$ & Yes \\
\hline $\mathrm{Te}-125 \mathrm{~m}$ & $2.04 \mathrm{E}-89$ & $4.74 \mathrm{E}-91$ & \\
\hline Th-227 & $1.05 \mathrm{E}-05$ & $2.44 \mathrm{E}-07$ & \\
\hline Th-228 & $1.19 \mathrm{E}-03$ & $2.77 \mathrm{E}-05$ & \\
\hline Th-229 & $3.10 \mathrm{E}-03$ & $7.21 \mathrm{E}-05$ & \\
\hline Th-230 & $8.53 \mathrm{E}-04$ & $1.98 \mathrm{E}-05$ & \\
\hline Th-231 & $6.20 \mathrm{E}-04$ & $1.44 \mathrm{E}-05$ & \\
\hline Th-232 & $1.19 \mathrm{E}-03$ & $2.77 \mathrm{E}-05$ & \\
\hline Th-234 & $1.60 \mathrm{E}-02$ & $3.72 \mathrm{E}-04$ & \\
\hline Tl-206 & $2.07 \mathrm{E}-10$ & $4.82 \mathrm{E}-12$ & \\
\hline Tl-207 & $1.06 \mathrm{E}-05$ & $2.47 \mathrm{E}-07$ & \\
\hline Tl-208 & $4.28 \mathrm{E}-04$ & $9.95 \mathrm{E}-06$ & \\
\hline Tl-209 & $6.69 \mathrm{E}-05$ & $1.56 \mathrm{E}-06$ & \\
\hline Tl-210 & $3.45 \mathrm{E}-08$ & $8.02 \mathrm{E}-10$ & \\
\hline U-233 & $4.22 \mathrm{E}-02$ & $9.81 \mathrm{E}-04$ & Yes \\
\hline U-234 & $9.11 \mathrm{E}-02$ & $2.12 \mathrm{E}-03$ & Yes \\
\hline U-235 & $6.20 \mathrm{E}-04$ & $1.44 \mathrm{E}-05$ & \\
\hline U-235m & $1.06 \mathrm{E}+01$ & $2.46 \mathrm{E}-01$ & \\
\hline U-236 & $9.85 \mathrm{E}-04$ & $2.29 \mathrm{E}-05$ & \\
\hline U-237 & $6.25 \mathrm{E}-08$ & $1.45 \mathrm{E}-09$ & \\
\hline U-238 & $1.60 \mathrm{E}-02$ & $3.72 \mathrm{E}-04$ & Yes \\
\hline U-240 & $8.83 \mathrm{E}-12$ & $2.06 \mathrm{E}-13$ & \\
\hline Y-90 & $5.10 \mathrm{E}-05$ & $1.19 \mathrm{E}-06$ & \\
\hline Zr-93 & $4.63 \mathrm{E}-01$ & $1.08 \mathrm{E}-02$ & Yes \\
\hline TOTAL & $4.30 \mathrm{E}+01$ & $1.00 \mathrm{E}+00$ & \\
\hline
\end{tabular}


SRNL-STI-2012-00294

Revision 0

\begin{tabular}{|c|c|c|c|}
\hline Nuclide & $\begin{array}{l}\text { Y } 2915 \\
\mu \mathrm{Ci} / \mathrm{g}\end{array}$ & $\begin{array}{c}\text { Fraction of } \\
\text { Activity }\end{array}$ & Reportable \\
\hline Ac-225 & $3.47 \mathrm{E}-03$ & $8.53 \mathrm{E}-05$ & \\
\hline Ac-227 & $1.19 \mathrm{E}-05$ & 2.94E-07 & \\
\hline Ac-228 & $1.19 \mathrm{E}-03$ & $2.93 \mathrm{E}-05$ & \\
\hline Am-241 & $8.80 \mathrm{E}+00$ & $2.17 \mathrm{E}-01$ & Yes \\
\hline Am-242 & $3.82 \mathrm{E}-04$ & $9.40 \mathrm{E}-06$ & \\
\hline Am-242m & $3.84 \mathrm{E}-04$ & $9.45 \mathrm{E}-06$ & \\
\hline Am-243 & $4.58 \mathrm{E}-01$ & $1.13 \mathrm{E}-02$ & Yes \\
\hline At-215 & $4.78 \mathrm{E}-11$ & $1.18 \mathrm{E}-12$ & \\
\hline At-217 & $3.47 \mathrm{E}-03$ & $8.53 \mathrm{E}-05$ & \\
\hline At-218 & $3.71 \mathrm{E}-08$ & $9.12 \mathrm{E}-10$ & \\
\hline At-219 & $9.89 \mathrm{E}-12$ & $2.43 \mathrm{E}-13$ & \\
\hline Ba-133 & $3.03 \mathrm{E}-27$ & 7.46E-29 & \\
\hline $\mathrm{Ba}-137 \mathrm{~m}$ & $5.44 \mathrm{E}-07$ & $1.34 \mathrm{E}-08$ & \\
\hline Bi-209 & $5.83 \mathrm{E}-20$ & $1.43 \mathrm{E}-21$ & \\
\hline Bi-210 & $1.85 \mathrm{E}-04$ & $4.55 \mathrm{E}-06$ & \\
\hline Bi-211 & $1.19 \mathrm{E}-05$ & 2.94E-07 & \\
\hline Bi-212 & $1.19 \mathrm{E}-03$ & $2.93 \mathrm{E}-05$ & \\
\hline Bi-213 & $3.47 \mathrm{E}-03$ & $8.53 \mathrm{E}-05$ & \\
\hline Bi-214 & $1.95 \mathrm{E}-04$ & $4.80 \mathrm{E}-06$ & \\
\hline Bi-215 & $9.59 \mathrm{E}-12$ & $2.36 \mathrm{E}-13$ & \\
\hline Bk-247 & $2.30 \mathrm{E}-04$ & $5.66 \mathrm{E}-06$ & \\
\hline Cd-113 & $8.54 \mathrm{E}-18$ & $2.10 \mathrm{E}-19$ & \\
\hline $\mathrm{Cd}-113 \mathrm{~m}$ & $1.76 \mathrm{E}-19$ & 4.32E-21 & \\
\hline Cf-249 & $3.95 \mathrm{E}-04$ & $9.72 \mathrm{E}-06$ & \\
\hline Cf-250 & $5.94 \mathrm{E}-26$ & $1.46 \mathrm{E}-27$ & \\
\hline Cf-251 & $2.54 \mathrm{E}-03$ & $6.25 \mathrm{E}-05$ & \\
\hline Cf-252 & $3.56 \mathrm{E}-105$ & $8.77 \mathrm{E}-107$ & \\
\hline $\mathrm{Cl}-36$ & $4.06 \mathrm{E}-03$ & $1.00 \mathrm{E}-04$ & Yes \\
\hline $\mathrm{Cm}-242$ & $3.19 \mathrm{E}-04$ & $7.85 \mathrm{E}-06$ & \\
\hline $\mathrm{Cm}-243$ & $2.51 \mathrm{E}-10$ & $6.19 \mathrm{E}-12$ & \\
\hline $\mathrm{Cm}-244$ & $1.43 \mathrm{E}-14$ & $3.53 \mathrm{E}-16$ & \\
\hline $\mathrm{Cm}-245$ & $2.52 \mathrm{E}-03$ & $6.20 \mathrm{E}-05$ & \\
\hline $\mathrm{Cm}-246$ & $5.78 \mathrm{E}-03$ & $1.42 \mathrm{E}-04$ & Yes \\
\hline $\mathrm{Cm}-247$ & $1.76 \mathrm{E}-07$ & 4.34E-09 & \\
\hline $\mathrm{Cm}-248$ & $1.39 \mathrm{E}-06$ & $3.41 \mathrm{E}-08$ & \\
\hline Co-60 & $7.42 \mathrm{E}-52$ & $1.83 \mathrm{E}-53$ & \\
\hline Cs- 135 & $3.32 \mathrm{E}-03$ & $8.17 \mathrm{E}-05$ & \\
\hline Cs-137 & $5.76 \mathrm{E}-07$ & $1.42 \mathrm{E}-08$ & \\
\hline Eu-154 & 3.23E-31 & 7.95E-33 & \\
\hline Eu-155 & $2.15 \mathrm{E}-57$ & $5.30 \mathrm{E}-59$ & \\
\hline Fr-221 & $3.47 \mathrm{E}-03$ & $8.53 \mathrm{E}-05$ & \\
\hline Fr-223 & $1.65 \mathrm{E}-07$ & 4.06E-09 & \\
\hline $\mathrm{Hg}-206$ & $3.52 \mathrm{E}-12$ & $8.66 \mathrm{E}-14$ & \\
\hline I-129 & $1.06 \mathrm{E}-03$ & $2.61 \mathrm{E}-05$ & \\
\hline $\mathrm{Nb}-93 \mathrm{~m}$ & $4.51 \mathrm{E}-01$ & $1.11 \mathrm{E}-02$ & Yes \\
\hline $\mathrm{Ni}-59$ & $2.55 \mathrm{E}+00$ & $6.27 \mathrm{E}-02$ & Yes \\
\hline $\mathrm{Ni}-63$ & $3.18 \mathrm{E}-01$ & 7.82E-03 & Yes \\
\hline Np-237 & $3.04 \mathrm{E}-02$ & 7.47E-04 & Yes \\
\hline Np-238 & $1.78 \mathrm{E}-06$ & $4.37 \mathrm{E}-08$ & \\
\hline Np-239 & $4.58 \mathrm{E}-01$ & $1.13 \mathrm{E}-02$ & \\
\hline Np-240 & $9.93 \mathrm{E}-12$ & $2.45 \mathrm{E}-13$ & \\
\hline $\mathrm{Pa}-231$ & $1.23 \mathrm{E}-05$ & $3.04 \mathrm{E}-07$ & \\
\hline $\mathrm{Pa}-233$ & $3.04 \mathrm{E}-02$ & 7.47E-04 & \\
\hline $\mathrm{Pa}-234$ & $2.40 \mathrm{E}-05$ & $5.91 \mathrm{E}-07$ & \\
\hline Pa-234m & $1.60 \mathrm{E}-02$ & 3.94E-04 & \\
\hline Pb-209 & $3.47 \mathrm{E}-03$ & $8.53 \mathrm{E}-05$ & \\
\hline $\mathrm{Pb}-210$ & $1.85 \mathrm{E}-04$ & $4.56 \mathrm{E}-06$ & \\
\hline $\mathrm{Pb}-211$ & $1.19 \mathrm{E}-05$ & 2.94E-07 & \\
\hline $\mathrm{Pb}-212$ & $1.19 \mathrm{E}-03$ & 2.93E-05 & \\
\hline $\mathrm{Pb}-214$ & $1.95 \mathrm{E}-04$ & $4.80 \mathrm{E}-06$ & \\
\hline
\end{tabular}

\begin{tabular}{|c|c|c|c|}
\hline Nuclide & $\begin{array}{l}\text { Y } 2915 \\
\mu \mathrm{Ci} / \mathrm{g}\end{array}$ & $\begin{array}{c}\text { Fraction of } \\
\text { Activity }\end{array}$ & Reportable \\
\hline Pd-107 & $1.22 \mathrm{E}-03$ & $3.00 \mathrm{E}-05$ & \\
\hline Pm-147 & $4.20 \mathrm{E}-102$ & $1.03 \mathrm{E}-103$ & \\
\hline Po-210 & $1.85 \mathrm{E}-04$ & $4.55 \mathrm{E}-06$ & \\
\hline Po-211 & $3.26 \mathrm{E}-08$ & $8.02 \mathrm{E}-10$ & \\
\hline Po-212 & $7.62 \mathrm{E}-04$ & $1.88 \mathrm{E}-05$ & \\
\hline Po-213 & $3.39 \mathrm{E}-03$ & $8.35 \mathrm{E}-05$ & \\
\hline Рo-214 & $1.95 \mathrm{E}-04$ & $4.80 \mathrm{E}-06$ & \\
\hline Po-215 & $1.19 \mathrm{E}-05$ & $2.94 \mathrm{E}-07$ & \\
\hline Po-216 & $1.19 \mathrm{E}-03$ & $2.93 \mathrm{E}-05$ & \\
\hline Po-218 & $1.95 \mathrm{E}-04$ & 4.80E-06 & \\
\hline $\mathrm{Pu}-238$ & $1.14 \mathrm{E}-01$ & $2.80 \mathrm{E}-03$ & Yes \\
\hline $\mathrm{Pu}-239$ & $1.05 \mathrm{E}+01$ & $2.59 \mathrm{E}-01$ & Yes \\
\hline $\mathrm{Pu}-240$ & $3.31 \mathrm{E}+00$ & $8.15 \mathrm{E}-02$ & Yes \\
\hline $\mathrm{Pu}-241$ & $2.52 \mathrm{E}-03$ & $6.21 \mathrm{E}-05$ & \\
\hline $\mathrm{Pu}-242$ & 8.98E-03 & $2.21 \mathrm{E}-04$ & Yes \\
\hline $\mathrm{Pu}-243$ & $1.76 \mathrm{E}-07$ & 4.34E-09 & \\
\hline $\mathrm{Pu}-244$ & $9.95 \mathrm{E}-12$ & $2.45 \mathrm{E}-13$ & \\
\hline Ra-223 & $1.19 \mathrm{E}-05$ & 2.94E-07 & \\
\hline Ra-224 & $1.19 \mathrm{E}-03$ & 2.93E-05 & \\
\hline Ra-225 & $3.47 \mathrm{E}-03$ & $8.53 \mathrm{E}-05$ & \\
\hline Ra-226 & $1.95 \mathrm{E}-04$ & $4.80 \mathrm{E}-06$ & \\
\hline Ra-228 & $1.19 \mathrm{E}-03$ & $2.93 \mathrm{E}-05$ & \\
\hline $\mathrm{Rn}-217$ & $4.16 \mathrm{E}-07$ & $1.02 \mathrm{E}-08$ & \\
\hline Rn-218 & $3.71 \mathrm{E}-11$ & $9.12 \mathrm{E}-13$ & \\
\hline Rn-219 & $1.19 \mathrm{E}-05$ & 2.94E-07 & \\
\hline $\mathrm{Rn}-220$ & $1.19 \mathrm{E}-03$ & $2.93 \mathrm{E}-05$ & \\
\hline Rn-222 & $1.95 \mathrm{E}-04$ & $4.80 \mathrm{E}-06$ & \\
\hline Sb-125 & $1.05 \mathrm{E}-99$ & $2.58 \mathrm{E}-101$ & \\
\hline $\mathrm{Sb}-126$ & $9.82 \mathrm{E}-02$ & $2.42 \mathrm{E}-03$ & \\
\hline $\mathrm{Sb}-126 \mathrm{~m}$ & $7.01 \mathrm{E}-01$ & $1.73 \mathrm{E}-02$ & \\
\hline Sb-126m2 & 4.69E-01 & $1.16 \mathrm{E}-02$ & \\
\hline Se-79 & $1.54 \mathrm{E}-02$ & 3.79E-04 & Yes \\
\hline Sm-147 & $4.28 \mathrm{E}-09$ & $1.05 \mathrm{E}-10$ & \\
\hline Sm-151 & 2.36E-01 & $5.80 \mathrm{E}-03$ & Yes \\
\hline Sn-121 & $4.39 \mathrm{E}-06$ & $1.08 \mathrm{E}-07$ & \\
\hline $\mathrm{Sn}-121 \mathrm{~m}$ & $5.65 \mathrm{E}-06$ & $1.39 \mathrm{E}-07$ & \\
\hline Sn-126 & $7.01 \mathrm{E}-01$ & $1.73 \mathrm{E}-02$ & Yes \\
\hline Sr-90 & 4.59E-06 & $1.13 \mathrm{E}-07$ & \\
\hline Tc-99 & 9.64E-02 & $2.37 \mathrm{E}-03$ & Yes \\
\hline $\mathrm{Te}-125 \mathrm{~m}$ & $2.49 \mathrm{E}-100$ & $6.13 \mathrm{E}-102$ & \\
\hline Th-227 & $1.18 \mathrm{E}-05$ & $2.90 \mathrm{E}-07$ & \\
\hline Th-228 & $1.19 \mathrm{E}-03$ & $2.93 \mathrm{E}-05$ & \\
\hline Th-229 & $3.47 \mathrm{E}-03$ & 8.53E-05 & \\
\hline Th-230 & $9.36 \mathrm{E}-04$ & $2.30 \mathrm{E}-05$ & \\
\hline Th-231 & $6.22 \mathrm{E}-04$ & $1.53 \mathrm{E}-05$ & \\
\hline Th-232 & $1.19 \mathrm{E}-03$ & 2.93E-05 & \\
\hline Th-234 & $1.60 \mathrm{E}-02$ & 3.94E-04 & \\
\hline Tl-206 & $2.48 \mathrm{E}-10$ & $6.10 \mathrm{E}-12$ & \\
\hline Tl-207 & $1.19 \mathrm{E}-05$ & $2.93 \mathrm{E}-07$ & \\
\hline Tl-208 & $4.28 \mathrm{E}-04$ & $1.05 \mathrm{E}-05$ & \\
\hline Tl-209 & 7.49E-05 & $1.84 \mathrm{E}-06$ & \\
\hline $\mathrm{Tl}-210$ & 4.10E-08 & $1.01 \mathrm{E}-09$ & \\
\hline U-233 & $4.21 \mathrm{E}-02$ & $1.04 \mathrm{E}-03$ & Yes \\
\hline U-234 & $9.11 \mathrm{E}-02$ & $2.24 \mathrm{E}-03$ & Yes \\
\hline U-235 & $6.22 \mathrm{E}-04$ & $1.53 \mathrm{E}-05$ & \\
\hline $\mathrm{U}-235 \mathrm{~m}$ & $1.05 \mathrm{E}+01$ & $2.59 \mathrm{E}-01$ & \\
\hline U-236 & $9.95 \mathrm{E}-04$ & $2.45 \mathrm{E}-05$ & \\
\hline U-237 & $6.21 \mathrm{E}-08$ & $1.53 \mathrm{E}-09$ & \\
\hline U-238 & $1.60 \mathrm{E}-02$ & 3.94E-04 & Yes \\
\hline $\mathrm{U}-240$ & $9.93 \mathrm{E}-12$ & $2.45 \mathrm{E}-13$ & \\
\hline Y-90 & $4.59 \mathrm{E}-06$ & $1.13 \mathrm{E}-07$ & \\
\hline Zr-93 & 4.63E-01 & $1.14 \mathrm{E}-02$ & Yes \\
\hline TOTAL & $4.06 \mathrm{E}+01$ & $1.00 \mathrm{E}+00$ & \\
\hline
\end{tabular}




\section{APPENDIX K. ACTIVITIES OF DRIED SLUDGE IN YEAR $3015(\mu \mathrm{Ci} / \mathrm{g})$}


SRNL-STI-2012-00294

Revision 0

\begin{tabular}{|c|c|c|c|}
\hline Nuclide & $\begin{array}{l}\text { Y } 3015 \\
\mu \mathrm{Ci} / \mathrm{g}\end{array}$ & $\begin{array}{c}\text { Fraction of } \\
\text { Activity }\end{array}$ & Reportable \\
\hline Ac-225 & $3.83 \mathrm{E}-03$ & $9.85 \mathrm{E}-05$ & \\
\hline Ac-227 & $1.32 \mathrm{E}-05$ & $3.40 \mathrm{E}-07$ & \\
\hline Ac-228 & $1.19 \mathrm{E}-03$ & $3.06 \mathrm{E}-05$ & \\
\hline Am-241 & $7.49 \mathrm{E}+00$ & $1.93 \mathrm{E}-01$ & Yes \\
\hline Am-242 & $2.34 \mathrm{E}-04$ & 6.01E-06 & \\
\hline Am- $242 m$ & $2.35 \mathrm{E}-04$ & $6.04 \mathrm{E}-06$ & \\
\hline Am-243 & 4.54E-01 & $1.17 \mathrm{E}-02$ & Yes \\
\hline At-215 & $5.29 \mathrm{E}-11$ & $1.36 \mathrm{E}-12$ & \\
\hline At-217 & $3.83 \mathrm{E}-03$ & $9.85 \mathrm{E}-05$ & \\
\hline At-218 & 4.34E-08 & 1.12E-09 & \\
\hline At-219 & $1.10 \mathrm{E}-11$ & $2.82 \mathrm{E}-13$ & \\
\hline Ba-133 & $4.22 \mathrm{E}-30$ & $1.09 \mathrm{E}-31$ & \\
\hline Ba-137m & $5.41 \mathrm{E}-08$ & 1.39E-09 & \\
\hline Bi-209 & 7.16E-20 & $1.84 \mathrm{E}-21$ & \\
\hline Bi-210 & $2.18 \mathrm{E}-04$ & $5.60 \mathrm{E}-06$ & \\
\hline Bi-211 & $1.32 \mathrm{E}-05$ & $3.40 \mathrm{E}-07$ & \\
\hline Bi-212 & 1.19E-03 & $3.06 \mathrm{E}-05$ & \\
\hline Bi-213 & $3.83 \mathrm{E}-03$ & $9.85 \mathrm{E}-05$ & \\
\hline Bi-214 & $2.28 \mathrm{E}-04$ & $5.87 \mathrm{E}-06$ & \\
\hline $\mathrm{Bi}-215$ & $1.06 \mathrm{E}-11$ & $2.73 \mathrm{E}-13$ & \\
\hline Bk-247 & 2.19E-04 & $5.63 \mathrm{E}-06$ & \\
\hline Cd-113 & $8.54 \mathrm{E}-18$ & $2.20 \mathrm{E}-19$ & \\
\hline Cd-113m & $1.29 \mathrm{E}-21$ & $3.31 \mathrm{E}-23$ & \\
\hline Cf-249 & $3.24 \mathrm{E}-04$ & $8.34 \mathrm{E}-06$ & \\
\hline Cf- 250 & $2.97 \mathrm{E}-28$ & $7.63 \mathrm{E}-30$ & \\
\hline Cf-251 & $2.35 \mathrm{E}-03$ & $6.05 \mathrm{E}-05$ & \\
\hline Cf-252 & $1.48 \mathrm{E}-116$ & $3.81 \mathrm{E}-118$ & \\
\hline $\mathrm{Cl}-36$ & $4.06 \mathrm{E}-03$ & $1.04 \mathrm{E}-04$ & Yes \\
\hline $\mathrm{Cm}-242$ & $1.95 \mathrm{E}-04$ & $5.02 \mathrm{E}-06$ & \\
\hline $\mathrm{Cm}-243$ & $2.49 \mathrm{E}-11$ & $6.41 \mathrm{E}-13$ & \\
\hline $\mathrm{Cm}-244$ & $3.05 \mathrm{E}-16$ & $7.84 \mathrm{E}-18$ & \\
\hline $\mathrm{Cm}-245$ & $2.50 \mathrm{E}-03$ & $6.44 \mathrm{E}-05$ & \\
\hline $\mathrm{Cm}-246$ & $5.70 \mathrm{E}-03$ & $1.47 \mathrm{E}-04$ & Yes \\
\hline $\mathrm{Cm}-247$ & $1.87 \mathrm{E}-07$ & 4.81E-09 & \\
\hline $\mathrm{Cm}-248$ & $1.39 \mathrm{E}-06$ & $3.56 \mathrm{E}-08$ & \\
\hline Co-60 & $1.44 \mathrm{E}-57$ & $3.71 \mathrm{E}-59$ & \\
\hline Cs- 135 & $3.32 \mathrm{E}-03$ & 8.54E-05 & \\
\hline Cs-137 & $5.73 \mathrm{E}-08$ & $1.47 \mathrm{E}-09$ & \\
\hline Eu-154 & $1.01 \mathrm{E}-34$ & $2.61 \mathrm{E}-36$ & \\
\hline Eu-155 & $9.99 \mathrm{E}-64$ & $2.57 \mathrm{E}-65$ & \\
\hline Fr-221 & $3.83 \mathrm{E}-03$ & $9.85 \mathrm{E}-05$ & \\
\hline Fr-223 & $1.83 \mathrm{E}-07$ & 4.70E-09 & \\
\hline $\mathrm{Hg}-206$ & 4.13E-12 & $1.06 \mathrm{E}-13$ & \\
\hline I-129 & $1.06 \mathrm{E}-03$ & $2.73 \mathrm{E}-05$ & \\
\hline $\mathrm{Nb}-93 \mathrm{~m}$ & $4.51 \mathrm{E}-01$ & $1.16 \mathrm{E}-02$ & Yes \\
\hline $\mathrm{Ni}-59$ & $2.55 \mathrm{E}+00$ & $6.55 \mathrm{E}-02$ & Yes \\
\hline $\mathrm{Ni}-63$ & $1.60 \mathrm{E}-01$ & $4.10 \mathrm{E}-03$ & Yes \\
\hline Np-237 & $3.06 \mathrm{E}-02$ & $7.88 \mathrm{E}-04$ & Yes \\
\hline Np-238 & $1.09 \mathrm{E}-06$ & $2.80 \mathrm{E}-08$ & \\
\hline Np-239 & 4.54E-01 & $1.17 \mathrm{E}-02$ & \\
\hline Np-240 & $1.10 \mathrm{E}-11$ & $2.84 \mathrm{E}-13$ & \\
\hline $\mathrm{Pa}-231$ & $1.36 \mathrm{E}-05$ & $3.51 \mathrm{E}-07$ & \\
\hline $\mathrm{Pa}-233$ & $3.06 \mathrm{E}-02$ & $7.88 \mathrm{E}-04$ & \\
\hline $\mathrm{Pa}-234$ & $2.40 \mathrm{E}-05$ & $6.17 \mathrm{E}-07$ & \\
\hline $\mathrm{Pa}-234 \mathrm{~m}$ & $1.60 \mathrm{E}-02$ & $4.12 \mathrm{E}-04$ & \\
\hline Pb-209 & $3.83 \mathrm{E}-03$ & $9.85 \mathrm{E}-05$ & \\
\hline $\mathrm{Pb}-210$ & $2.18 \mathrm{E}-04$ & $5.60 \mathrm{E}-06$ & \\
\hline $\mathrm{Pb}-211$ & $1.32 \mathrm{E}-05$ & $3.40 \mathrm{E}-07$ & \\
\hline $\mathrm{Pb}-212$ & $1.19 \mathrm{E}-03$ & $3.06 \mathrm{E}-05$ & \\
\hline $\mathrm{Pb}-214$ & $2.28 \mathrm{E}-04$ & $5.87 \mathrm{E}-06$ & \\
\hline
\end{tabular}

\begin{tabular}{|c|c|c|c|}
\hline Nuclide & $\begin{array}{l}\text { Y } 3015 \\
\mu \mathrm{Ci} / \mathrm{g}\end{array}$ & $\begin{array}{c}\text { Fraction of } \\
\text { Activity }\end{array}$ & Reportable \\
\hline Pd-107 & $1.22 \mathrm{E}-03$ & $3.14 \mathrm{E}-05$ & \\
\hline Pm-147 & $1.41 \mathrm{E}-113$ & $3.62 \mathrm{E}-115$ & \\
\hline Po-210 & $2.17 \mathrm{E}-04$ & $5.59 \mathrm{E}-06$ & \\
\hline Po-211 & $3.61 \mathrm{E}-08$ & $9.29 \mathrm{E}-10$ & \\
\hline Po-212 & $7.62 \mathrm{E}-04$ & $1.96 \mathrm{E}-05$ & \\
\hline Po-213 & $3.75 \mathrm{E}-03$ & $9.64 \mathrm{E}-05$ & \\
\hline Po-214 & $2.28 \mathrm{E}-04$ & $5.87 \mathrm{E}-06$ & \\
\hline Po-215 & $1.32 \mathrm{E}-05$ & $3.40 \mathrm{E}-07$ & \\
\hline Po-216 & $1.19 \mathrm{E}-03$ & $3.06 \mathrm{E}-05$ & \\
\hline Po-218 & $2.28 \mathrm{E}-04$ & $5.87 \mathrm{E}-06$ & \\
\hline $\mathrm{Pu}-238$ & $5.17 \mathrm{E}-02$ & $1.33 \mathrm{E}-03$ & Yes \\
\hline $\mathrm{Pu}-239$ & $1.05 \mathrm{E}+01$ & $2.70 \mathrm{E}-01$ & Yes \\
\hline $\mathrm{Pu}-240$ & $3.27 \mathrm{E}+00$ & $8.42 \mathrm{E}-02$ & Yes \\
\hline $\mathrm{Pu}-241$ & $2.51 \mathrm{E}-03$ & $6.45 \mathrm{E}-05$ & \\
\hline $\mathrm{Pu}-242$ & $8.98 \mathrm{E}-03$ & $2.31 \mathrm{E}-04$ & Yes \\
\hline $\mathrm{Pu}-243$ & $1.87 \mathrm{E}-07$ & 4.81E-09 & \\
\hline $\mathrm{Pu}-244$ & $1.11 \mathrm{E}-11$ & $2.84 \mathrm{E}-13$ & \\
\hline $\mathrm{Ra}-223$ & $1.32 \mathrm{E}-05$ & $3.40 \mathrm{E}-07$ & \\
\hline $\mathrm{Ra}-224$ & $1.19 \mathrm{E}-03$ & $3.06 \mathrm{E}-05$ & \\
\hline $\mathrm{Ra}-225$ & $3.83 \mathrm{E}-03$ & $9.85 \mathrm{E}-05$ & \\
\hline $\mathrm{Ra}-226$ & $2.28 \mathrm{E}-04$ & $5.87 \mathrm{E}-06$ & \\
\hline $\mathrm{Ra}-228$ & $1.19 \mathrm{E}-03$ & $3.06 \mathrm{E}-05$ & \\
\hline Rn-217 & 4.60E-07 & $1.18 \mathrm{E}-08$ & \\
\hline $\mathrm{Rn}-218$ & $4.34 \mathrm{E}-11$ & $1.12 \mathrm{E}-12$ & \\
\hline Rn-219 & $1.32 \mathrm{E}-05$ & $3.40 \mathrm{E}-07$ & \\
\hline $\mathrm{Rn}-220$ & $1.19 \mathrm{E}-03$ & $3.06 \mathrm{E}-05$ & \\
\hline Rn-222 & $2.28 \mathrm{E}-04$ & $5.87 \mathrm{E}-06$ & \\
\hline Sb-125 & $1.28 \mathrm{E}-110$ & $3.30 \mathrm{E}-112$ & \\
\hline $\mathrm{Sb}-126$ & $9.81 \mathrm{E}-02$ & $2.52 \mathrm{E}-03$ & \\
\hline Sb-126m & 7.01E-01 & $1.80 \mathrm{E}-02$ & \\
\hline $\mathrm{Sb}-126 \mathrm{~m} 2$ & 4.69E-01 & $1.21 \mathrm{E}-02$ & \\
\hline Se-79 & $1.54 \mathrm{E}-02$ & $3.96 \mathrm{E}-04$ & Yes \\
\hline Sm-147 & $4.28 \mathrm{E}-09$ & $1.10 \mathrm{E}-10$ & \\
\hline Sm-151 & $1.09 \mathrm{E}-01$ & $2.81 \mathrm{E}-03$ & Yes \\
\hline Sn-121 & $1.24 \mathrm{E}-06$ & $3.20 \mathrm{E}-08$ & \\
\hline Sn-121m & $1.60 \mathrm{E}-06$ & 4.13E-08 & \\
\hline Sn-126 & $7.01 \mathrm{E}-01$ & $1.80 \mathrm{E}-02$ & Yes \\
\hline $\mathrm{Sr}-90$ & $4.14 \mathrm{E}-07$ & $1.06 \mathrm{E}-08$ & \\
\hline Tc-99 & $9.64 \mathrm{E}-02$ & $2.48 \mathrm{E}-03$ & Yes \\
\hline $\mathrm{Te}-125 \mathrm{~m}$ & $3.05 \mathrm{E}-111$ & $7.84 \mathrm{E}-113$ & \\
\hline Th-227 & $1.31 \mathrm{E}-05$ & $3.36 \mathrm{E}-07$ & \\
\hline Th-228 & $1.19 \mathrm{E}-03$ & $3.06 \mathrm{E}-05$ & \\
\hline Th-229 & $3.83 \mathrm{E}-03$ & $9.85 \mathrm{E}-05$ & \\
\hline Th-230 & $1.02 \mathrm{E}-03$ & $2.62 \mathrm{E}-05$ & \\
\hline Th-231 & $6.23 \mathrm{E}-04$ & $1.60 \mathrm{E}-05$ & \\
\hline Th-232 & $1.19 \mathrm{E}-03$ & $3.06 \mathrm{E}-05$ & \\
\hline Th-234 & $1.60 \mathrm{E}-02$ & $4.12 \mathrm{E}-04$ & \\
\hline Tl-206 & $2.91 \mathrm{E}-10$ & 7.49E-12 & \\
\hline Tl-207 & $1.32 \mathrm{E}-05$ & $3.39 \mathrm{E}-07$ & \\
\hline Tl-208 & $4.28 \mathrm{E}-04$ & $1.10 \mathrm{E}-05$ & \\
\hline Tl-209 & $8.27 \mathrm{E}-05$ & $2.13 \mathrm{E}-06$ & \\
\hline Tl-210 & 4.79E-08 & $1.23 \mathrm{E}-09$ & \\
\hline U-233 & $4.21 \mathrm{E}-02$ & $1.08 \mathrm{E}-03$ & Yes \\
\hline U-234 & $9.11 \mathrm{E}-02$ & $2.34 \mathrm{E}-03$ & Yes \\
\hline U-235 & $6.23 \mathrm{E}-04$ & $1.60 \mathrm{E}-05$ & \\
\hline U-235m & $1.05 \mathrm{E}+01$ & $2.70 \mathrm{E}-01$ & \\
\hline U-236 & $1.00 \mathrm{E}-03$ & $2.58 \mathrm{E}-05$ & \\
\hline U-237 & $6.17 \mathrm{E}-08$ & $1.59 \mathrm{E}-09$ & \\
\hline U-238 & $1.60 \mathrm{E}-02$ & $4.12 \mathrm{E}-04$ & Yes \\
\hline U-240 & $1.10 \mathrm{E}-11$ & $2.84 \mathrm{E}-13$ & \\
\hline Y-90 & 4.14E-07 & $1.06 \mathrm{E}-08$ & \\
\hline Zr-93 & $4.63 \mathrm{E}-01$ & $1.19 \mathrm{E}-02$ & Yes \\
\hline TOTAL & $3.89 \mathrm{E}+01$ & $1.00 \mathrm{E}+00$ & \\
\hline
\end{tabular}


SRNL-STI-2012-00294

Revision 0

\begin{tabular}{|c|c|c|c|}
\hline Nuclide & $\begin{array}{c}\mathrm{Y} 3115 \\
\mu \mathrm{Ci} / \mathrm{g}\end{array}$ & $\begin{array}{c}\text { Fraction of } \\
\text { Activity }\end{array}$ & Reportable \\
\hline Ac-225 & $4.19 \mathrm{E}-03$ & $1.12 \mathrm{E}-04$ & \\
\hline Ac-227 & $1.45 \mathrm{E}-05$ & $3.87 \mathrm{E}-07$ & \\
\hline Ac-228 & $1.19 \mathrm{E}-03$ & $3.17 \mathrm{E}-05$ & \\
\hline Am-241 & $6.39 \mathrm{E}+00$ & $1.70 \mathrm{E}-01$ & Yes \\
\hline Am-242 & $1.43 \mathrm{E}-04$ & $3.81 \mathrm{E}-06$ & \\
\hline $\mathrm{Am}-242 \mathrm{~m}$ & $1.44 \mathrm{E}-04$ & $3.83 \mathrm{E}-06$ & \\
\hline Am-243 & $4.50 \mathrm{E}-01$ & $1.20 \mathrm{E}-02$ & Yes \\
\hline At-215 & $5.81 \mathrm{E}-11$ & $1.55 \mathrm{E}-12$ & \\
\hline At-217 & $4.19 \mathrm{E}-03$ & $1.12 \mathrm{E}-04$ & \\
\hline At-218 & $5.01 \mathrm{E}-08$ & 1.34E-09 & \\
\hline At-219 & $1.20 \mathrm{E}-11$ & $3.21 \mathrm{E}-13$ & \\
\hline Ba-133 & $5.88 \mathrm{E}-33$ & $1.57 \mathrm{E}-34$ & \\
\hline Ba-137m & $5.38 \mathrm{E}-09$ & $1.44 \mathrm{E}-10$ & \\
\hline Bi-209 & $8.62 \mathrm{E}-20$ & $2.30 \mathrm{E}-21$ & \\
\hline Bi-210 & $2.52 \mathrm{E}-04$ & $6.72 \mathrm{E}-06$ & \\
\hline Bi-211 & $1.45 \mathrm{E}-05$ & $3.87 \mathrm{E}-07$ & \\
\hline Bi-212 & 1.19E-03 & $3.17 \mathrm{E}-05$ & \\
\hline $\mathrm{Bi}-213$ & 4.19E-03 & $1.12 \mathrm{E}-04$ & \\
\hline Bi-214 & 2.64E-04 & 7.03E-06 & \\
\hline $\mathrm{Bi}-215$ & 1.17E-11 & $3.11 \mathrm{E}-13$ & \\
\hline Bk-247 & $2.08 \mathrm{E}-04$ & $5.55 \mathrm{E}-06$ & \\
\hline Cd-113 & $8.54 \mathrm{E}-18$ & $2.28 \mathrm{E}-19$ & \\
\hline Cd-113m & $9.43 \mathrm{E}-24$ & $2.51 \mathrm{E}-25$ & \\
\hline Cf-249 & $2.66 \mathrm{E}-04$ & $7.10 \mathrm{E}-06$ & \\
\hline Cf- 250 & $1.48 \mathrm{E}-30$ & $3.95 \mathrm{E}-32$ & \\
\hline Cf-251 & $2.18 \mathrm{E}-03$ & 5.81E-05 & \\
\hline Cf-252 & $6.17 \mathrm{E}-128$ & $1.64 \mathrm{E}-129$ & \\
\hline $\mathrm{Cl}-36$ & $4.06 \mathrm{E}-03$ & $1.08 \mathrm{E}-04$ & Yes \\
\hline $\mathrm{Cm}-242$ & $1.19 \mathrm{E}-04$ & $3.18 \mathrm{E}-06$ & \\
\hline $\mathrm{Cm}-243$ & $2.47 \mathrm{E}-12$ & $6.60 \mathrm{E}-14$ & \\
\hline $\mathrm{Cm}-244$ & $6.48 \mathrm{E}-18$ & $1.73 \mathrm{E}-19$ & \\
\hline $\mathrm{Cm}-245$ & 2.49E-03 & $6.63 \mathrm{E}-05$ & \\
\hline $\mathrm{Cm}-246$ & $5.62 \mathrm{E}-03$ & $1.50 \mathrm{E}-04$ & Yes \\
\hline $\mathrm{Cm}-247$ & $1.97 \mathrm{E}-07$ & 5.24E-09 & \\
\hline $\mathrm{Cm}-248$ & $1.38 \mathrm{E}-06$ & $3.69 \mathrm{E}-08$ & \\
\hline Co-60 & $2.81 \mathrm{E}-63$ & 7.49E-65 & \\
\hline Cs-135 & $3.32 \mathrm{E}-03$ & $8.85 \mathrm{E}-05$ & \\
\hline Cs-137 & $5.70 \mathrm{E}-09$ & $1.52 \mathrm{E}-10$ & \\
\hline Eu-154 & $3.18 \mathrm{E}-38$ & $8.48 \mathrm{E}-40$ & \\
\hline Eu-155 & $4.63 \mathrm{E}-70$ & $1.24 \mathrm{E}-71$ & \\
\hline Fr-221 & 4.19E-03 & $1.12 \mathrm{E}-04$ & \\
\hline Fr-223 & $2.00 \mathrm{E}-07$ & 5.34E-09 & \\
\hline Hg-206 & $4.79 \mathrm{E}-12$ & $1.28 \mathrm{E}-13$ & \\
\hline I-129 & $1.06 \mathrm{E}-03$ & $2.83 \mathrm{E}-05$ & \\
\hline Nb-93m & 4.51E-01 & $1.20 \mathrm{E}-02$ & Yes \\
\hline $\mathrm{Ni}-59$ & $2.54 \mathrm{E}+00$ & $6.79 \mathrm{E}-02$ & Yes \\
\hline $\mathrm{Ni}-63$ & $8.01 \mathrm{E}-02$ & $2.14 \mathrm{E}-03$ & Yes \\
\hline Np-237 & $3.08 \mathrm{E}-02$ & $8.23 \mathrm{E}-04$ & Yes \\
\hline Np-238 & $6.65 \mathrm{E}-07$ & $1.77 \mathrm{E}-08$ & \\
\hline Np-239 & $4.50 \mathrm{E}-01$ & $1.20 \mathrm{E}-02$ & \\
\hline Np-240 & $1.21 \mathrm{E}-11$ & $3.24 \mathrm{E}-13$ & \\
\hline $\mathrm{Pa}-231$ & $1.49 \mathrm{E}-05$ & $3.98 \mathrm{E}-07$ & \\
\hline $\mathrm{Pa}-233$ & $3.08 \mathrm{E}-02$ & 8.23E-04 & \\
\hline $\mathrm{Pa}-234$ & $2.40 \mathrm{E}-05$ & $6.40 \mathrm{E}-07$ & \\
\hline $\mathrm{Pa}-234 \mathrm{~m}$ & $1.60 \mathrm{E}-02$ & $4.27 \mathrm{E}-04$ & \\
\hline Pb-209 & 4.19E-03 & $1.12 \mathrm{E}-04$ & \\
\hline $\mathrm{Pb}-210$ & $2.52 \mathrm{E}-04$ & $6.72 \mathrm{E}-06$ & \\
\hline $\mathrm{Pb}-211$ & $1.45 \mathrm{E}-05$ & 3.87E-07 & \\
\hline $\mathrm{Pb}-212$ & $1.19 \mathrm{E}-03$ & $3.17 \mathrm{E}-05$ & \\
\hline $\mathrm{Pb}-214$ & $2.64 \mathrm{E}-04$ & 7.03E-06 & \\
\hline
\end{tabular}

\begin{tabular}{|c|c|c|c|}
\hline Nuclide & $\begin{array}{l}\mathrm{Y} 3115 \\
\mu \mathrm{Ci} / \mathrm{g}\end{array}$ & $\begin{array}{c}\text { Fraction of } \\
\text { Activity }\end{array}$ & Reportable \\
\hline Pd-107 & $1.22 \mathrm{E}-03$ & $3.25 \mathrm{E}-05$ & \\
\hline Pm-147 & $4.73 \mathrm{E}-125$ & $1.26 \mathrm{E}-126$ & \\
\hline Po-210 & $2.52 \mathrm{E}-04$ & $6.72 \mathrm{E}-06$ & \\
\hline Po-211 & $3.96 \mathrm{E}-08$ & $1.06 \mathrm{E}-09$ & \\
\hline Po-212 & $7.62 \mathrm{E}-04$ & $2.03 \mathrm{E}-05$ & \\
\hline Po-213 & $4.10 \mathrm{E}-03$ & $1.09 \mathrm{E}-04$ & \\
\hline Po-214 & 2.64E-04 & 7.03E-06 & \\
\hline Po-215 & $1.45 \mathrm{E}-05$ & $3.87 \mathrm{E}-07$ & \\
\hline Po-216 & $1.19 \mathrm{E}-03$ & $3.17 \mathrm{E}-05$ & \\
\hline Po-218 & $2.64 \mathrm{E}-04$ & 7.03E-06 & \\
\hline $\mathrm{Pu}-238$ & $2.36 \mathrm{E}-02$ & $6.28 \mathrm{E}-04$ & Yes \\
\hline $\mathrm{Pu}-239$ & $1.05 \mathrm{E}+01$ & $2.80 \mathrm{E}-01$ & Yes \\
\hline $\mathrm{Pu}-240$ & $3.24 \mathrm{E}+00$ & $8.64 \mathrm{E}-02$ & Yes \\
\hline $\mathrm{Pu}-241$ & $2.49 \mathrm{E}-03$ & $6.64 \mathrm{E}-05$ & \\
\hline $\mathrm{Pu}-242$ & $8.98 \mathrm{E}-03$ & $2.39 \mathrm{E}-04$ & Yes \\
\hline $\mathrm{Pu}-243$ & $1.97 \mathrm{E}-07$ & $5.24 \mathrm{E}-09$ & \\
\hline $\mathrm{Pu}-244$ & $1.22 \mathrm{E}-11$ & $3.24 \mathrm{E}-13$ & \\
\hline Ra-223 & $1.45 \mathrm{E}-05$ & 3.87E-07 & \\
\hline Ra-224 & $1.19 \mathrm{E}-03$ & $3.17 \mathrm{E}-05$ & \\
\hline $\mathrm{Ra}-225$ & $4.19 \mathrm{E}-03$ & $1.12 \mathrm{E}-04$ & \\
\hline $\mathrm{Ra}-226$ & $2.64 \mathrm{E}-04$ & $7.03 \mathrm{E}-06$ & \\
\hline $\mathrm{Ra}-228$ & $1.19 \mathrm{E}-03$ & $3.17 \mathrm{E}-05$ & \\
\hline Rn-217 & $5.03 \mathrm{E}-07$ & $1.34 \mathrm{E}-08$ & \\
\hline $\mathrm{Rn}-218$ & $5.01 \mathrm{E}-11$ & $1.34 \mathrm{E}-12$ & \\
\hline Rn-219 & $1.45 \mathrm{E}-05$ & $3.87 \mathrm{E}-07$ & \\
\hline $\mathrm{Rn}-220$ & $1.19 \mathrm{E}-03$ & $3.17 \mathrm{E}-05$ & \\
\hline $\mathrm{Rn}-222$ & $2.64 \mathrm{E}-04$ & 7.03E-06 & \\
\hline Sb-125 & $1.57 \mathrm{E}-121$ & $4.19 \mathrm{E}-123$ & \\
\hline $\mathrm{Sb}-126$ & $9.81 \mathrm{E}-02$ & $2.62 \mathrm{E}-03$ & \\
\hline $\mathrm{Sb}-126 \mathrm{~m}$ & $7.01 \mathrm{E}-01$ & $1.87 \mathrm{E}-02$ & \\
\hline $\mathrm{Sb}-126 \mathrm{~m} 2$ & 4.69E-01 & $1.25 \mathrm{E}-02$ & \\
\hline Se-79 & $1.54 \mathrm{E}-02$ & 4.10E-04 & Yes \\
\hline Sm-147 & $4.28 \mathrm{E}-09$ & $1.14 \mathrm{E}-10$ & \\
\hline Sm-151 & $5.05 \mathrm{E}-02$ & $1.35 \mathrm{E}-03$ & Yes \\
\hline Sn-121 & $3.53 \mathrm{E}-07$ & $9.41 \mathrm{E}-09$ & \\
\hline $\mathrm{Sn}-121 \mathrm{~m}$ & $4.55 \mathrm{E}-07$ & $1.21 \mathrm{E}-08$ & \\
\hline Sn-126 & 7.01E-01 & $1.87 \mathrm{E}-02$ & Yes \\
\hline Sr-90 & $3.72 \mathrm{E}-08$ & $9.93 \mathrm{E}-10$ & \\
\hline Tc-99 & $9.64 \mathrm{E}-02$ & $2.57 \mathrm{E}-03$ & Yes \\
\hline $\mathrm{Te}-125 \mathrm{~m}$ & $3.73 \mathrm{E}-122$ & $9.94 \mathrm{E}-124$ & \\
\hline Th-227 & $1.43 \mathrm{E}-05$ & $3.82 \mathrm{E}-07$ & \\
\hline Th-228 & $1.19 \mathrm{E}-03$ & $3.17 \mathrm{E}-05$ & \\
\hline Th-229 & $4.19 \mathrm{E}-03$ & $1.12 \mathrm{E}-04$ & Yes \\
\hline Th-230 & $1.10 \mathrm{E}-03$ & $2.94 \mathrm{E}-05$ & \\
\hline Th-231 & $6.24 \mathrm{E}-04$ & $1.66 \mathrm{E}-05$ & \\
\hline Th-232 & $1.19 \mathrm{E}-03$ & $3.17 \mathrm{E}-05$ & \\
\hline Th-234 & $1.60 \mathrm{E}-02$ & 4.27E-04 & \\
\hline Tl-206 & $3.38 \mathrm{E}-10$ & $9.00 \mathrm{E}-12$ & \\
\hline Tl-207 & $1.45 \mathrm{E}-05$ & $3.86 \mathrm{E}-07$ & \\
\hline Tl-208 & $4.28 \mathrm{E}-04$ & $1.14 \mathrm{E}-05$ & \\
\hline Tl-209 & $9.05 \mathrm{E}-05$ & $2.41 \mathrm{E}-06$ & \\
\hline Tl-210 & $5.53 \mathrm{E}-08$ & $1.48 \mathrm{E}-09$ & \\
\hline U-233 & $4.21 \mathrm{E}-02$ & $1.12 \mathrm{E}-03$ & Yes \\
\hline U-234 & $9.11 \mathrm{E}-02$ & $2.43 \mathrm{E}-03$ & Yes \\
\hline U-235 & $6.24 \mathrm{E}-04$ & $1.66 \mathrm{E}-05$ & \\
\hline U-235m & $1.05 \mathrm{E}+01$ & $2.79 \mathrm{E}-01$ & \\
\hline U-236 & $1.01 \mathrm{E}-03$ & $2.70 \mathrm{E}-05$ & \\
\hline U-237 & $6.12 \mathrm{E}-08$ & $1.63 \mathrm{E}-09$ & \\
\hline U-238 & $1.60 \mathrm{E}-02$ & 4.27E-04 & Yes \\
\hline U-240 & $1.21 \mathrm{E}-11$ & $3.24 \mathrm{E}-13$ & \\
\hline$Y-90$ & $3.72 \mathrm{E}-08$ & $9.93 \mathrm{E}-10$ & \\
\hline Zr-93 & $4.63 \mathrm{E}-01$ & $1.23 \mathrm{E}-02$ & Yes \\
\hline TOTAL & $3.75 \mathrm{E}+01$ & $1.00 \mathrm{E}+00$ & \\
\hline
\end{tabular}


This page intentionally left blank. 
Distribution:

K. M. Fox, 999-W

S. D. Fink, 773-A

C. C. Herman, 999-W

S. L. Marra, 773-A

F. M. Pennebaker, 773-42A

Records Administration (EDWS)

M. J. Barnes, 773-A

R. H. Young, 773-A

C. C. Diprete, 773-A

D. P. Diprete, 773-41A

J. P. Vaughan, 773-41A

C. J. Bannochie, 773-42A

J. M. Pareizs, 773-A

S. H. Reboul, 773-A

D. K. Peeler, 999-W

D. C. Koopman, 999-W

M. E. Stone, 999-W

D. P. Lambert, 999-W

J. D. Newell, 999-W

T. B. Edwards, 999-W

F. C. Johnson, 999-W

J. R. Zamecnik, 999-W

C. M. Jantzen, 773-A

D. J. Adamson, 999-W

J. M. Bricker, 704-27S

T. L. Fellinger, 704-26S

E. J. Freed, 704-S

A. Samadi-Dezfouli, 704-27S

J. M. Gillam, 766-H

B. A. Hamm, 766-H

E. W. Holtzscheiter, 704-15S

J. F. Iaukea, 704-30S

M. T. Keefer, 766-H

D. W. McIlmoyle, 766-H

J. W. Ray, 704-S

H. B. Shah, 766-H

D. C. Sherburne, 704-S

P. R. Jackson, DOE-SR, 703-46A

K. H. Subramanian, 766-H 